Feb/2020

Working Paper 20-05

rcea.org/RePEc/pdf/wp20-05.pdf

\title{
ACADEMIC SCHOLARSHIP IN LIGHT OF THE 2008 FinanCIAL CRISIS: TEXTUAL ANALYSIS OF NBER WORKING PAPERS
}

\author{
Daniel Levy \\ Bar-Ilan University, Israel \\ Emory University, USA \\ RCEA \\ Tamir Mayer \\ Bar-Ilan University, Israel \\ Alon Raviv \\ Bar-Ilan University, Israel
}

Copyright belongs to the author. Short sections of the text, not exceeding three paragraphs, can be used provided proper acknowledgement is given.

The Rimini Centre for Economic Analysis (RCEA) was established in March 2007. RCEA is a private, nonprofit organization dedicated to independent research in Applied and Theoretical Economics and related fields. RCEA organizes seminars and workshops, sponsors a general interest journal, the Review of Economic Analysis (REA), and organizes a biennial conference, the Rimini Conference in Economics and Finance (RCEF). Scientific work contributed by the RCEA Scholars is published in the RCEA Working Paper series.

The views expressed in this paper are those of the authors. No responsibility for them should be attributed to the Rimini Centre for Economic Analysis. 


\title{
Academic Scholarship in Light of the 2008 Financial Crisis: Textual Analysis of NBER Working Papers*
}

\author{
Daniel Levy \\ Department of Economics, Bar-Ilan University, Ramat-Gan 5290002, ISRAEL \\ Department of Economics, Emory University, Atlanta, GA 30322, USA \\ RCEA, University of Bologna, Rimini, ITALY \\ Daniel.Levy@biu.ac.il
}

Tamir Mayer

Graduate School of Business Administration, Bar-Ilan University, Ramat Gan, 5290002, ISRAEL Tamirmayer@gmail.com

\begin{abstract}
Alon Raviv ${ }^{\text {a }}$
Graduate School of Business Administration, Bar-Ilan University, Ramat Gan, 5290002, ISRAEL

Alon.Raviv@biu.ac.il
\end{abstract}

Revised: February 23, 2020

Textual analysis of the NBER Working Papers published during 1999-2016 is done to assess the effects of the 2007-2009 crisis on the academic literature. The volume of crisis-related WPs is counter-cyclical, lagging the financial-instability-index. WPs by the Monetary-Economics, Asset-Pricing, and CorporateFinance program members, hardly refer to "crisis/crises" in the pre-crisis period. As the crisis develops, however, their study-efforts of crisis-related issues increase rapidly, focusing on the links between 'Repoand-Securitization' and the crisis. In contrast, WPs in macroeconomics-related programs refer extensively to "crisis/crises" in the pre-crisis period. These WPs abandon topics of 'Sudden-Stop' and 'EmergingMarkets' as the crisis developed.

JEL Codes: $\quad$ A11, C38, C55, E32, E44, E52, E58, F30, G01, G20, G21, G28

Key Words: 2008 Financial Crisis, Financial Crises, Textual Analysis, LDA Topic Modeling, Securitization, Repo, Sudden Stop

\footnotetext{
* We thank Menachem (Meni) Abudy, Wendy Carlin, and Roy Gelbard, as well as the participants of the 2019 Workshop on "Sentiments and Crises in Financial Texts" at the Data Science Center at Bar-Ilan University, the 2019 Israeli Behavioral Finance Conference at the Academic College of Tel Aviv-Yaffo, and the research seminars at the Research Department of the Bank of Israel, and at the Department of Economics at Bar-Ilan University, for useful comments and suggestions. We thank Sara Markowitz for answering our questions about the way NBER working papers are processed and distributed. The usual disclaimer applies.
}

${ }^{\text {a }}$ Corresponding author

(C) 2020 by Daniel Levy, Tamir Mayer, and Alon Raviv. All rights reserved. Short sections of text, not to exceed two paragraphs, may be quoted without explicit permission provided that full credit, including $\odot$ notice, is given to the source. 
"Many professional economists now find themselves answering questions...on topics that did not seem at all central until a few years ago, and we are collectively scrambling to catch up."

G. Gorton and A. Metrick, J of Econ. Literature (2012, p. 128)

"The study of economics is driven by perceived economic problems, and when those problems seem to go away in the real economy, so does academic interest in the problem."

R. E. Krainer, Finance in a Theory of the Business Cycle (1992, p. xi)

"The function of these [NBER working] papers...is to get research out quickly...For economists, the WPs provide what amounts to one-stop shopping for new developments in their field."

P. Krugman, "Understanding NBER," NY Times (April 22, 2013)

\section{Introduction}

The global financial crisis of 2007-2009 turned out to be the most serious economic crisis since the Great Depression. It began in 2007 with a crisis in the subprime mortgage market in the US, and developed into an international banking crisis with the collapse of Lehman Brothers on September 15, 2008. The crisis was followed by a global economic slowdown, the Great Recession. The European debt crisis that followed the global banking crisis, turned out to be a multi-year debt crisis that has been battering the EU since the end of 2009, when several countries were unable to repay or refinance their debt, or to bail out their over-indebted banking institutions without external assistance.

As the financial crisis began to unfold, the public began criticizing the economics and finance scholars for failing to recognize the coming of the financial crisis. Criticism was heard from all directions including the press, the electronic media, and even from the late-night comedians. ${ }^{1}$ The criticism, however, was not limited to the general public. Many professional economists have joined the debate, expressing their critical views, sometimes using very strongly worded language, although not everyone agreed with them. A common element in many of the critical arguments made was that the economics and finance scholars relied too much on the rational actor paradigm, ignoring the evidence that the market participants often tend to act irrationally, which may drive markets in ways and directions that the standard models cannot anticipate.

Bernanke (2018) argues that the full nature of the crisis was not anticipated by the profession because economists significantly underestimated the impact of the crisis on the real economy. Moreover, existing models did not assign significant roles to many credit-related factors and consequently to the behavior of financial intermediaries. In other words, in the existing models, there was disconnect between real macroeconomy and financial markets. According to Razin

\footnotetext{
${ }^{1}$ The public discourse is ongoing. See, for example, a recent episode of "The Late Show" with Stephen Colbert, where Paul Krugman explains to Colbert about macroeconomic booms and busts, as the two men ride the Nitro roller coaster at 6-Flags Great Adventure: https://www.youtube.com/watch?v=ir7lwqnPlrg, accessed May 12, 2019.
} 
(2014), most theorists concede now that the pre-crisis monetarist consensus was mistaken.

Following the crisis, economists and policymakers began emphasizing the need to revise the economic models, acknowledging that the academic community was not engaged sufficiently in the study of crises, and that there was a need to refocus its attention on empirical questions, models, and policy recommendations that might better explain and help in coping with future crises (Goldstein and Razin 2015). These sentiments, however, are based on perceptions and qualitative assessments, as little has been done to explore systematically and to quantify the extent of the engagement of the academic community before and after the crisis in studying crisis-related issues.

Our goal in this paper is to measure and quantify the nature and the intensity of the academic efforts to study and understand the 2007-2009 financial crisis, as reflected in the academic finance and economics literature, published before, during, and after the crisis. In doing so, we address three specific questions. First, we assess the aggregate scholarly effort around the crisis by quantifying the intensity and the speed of the response of the finance and economics scholars as the crisis was evolving. Second, we analyze the variation across subfields of economics and finance to assess which fields and subfields of economics and finance have led the change. Third, we assess how the focus on different crisis-related topics evolved over time and what was the role of the different research communities in the process.

We address these questions by analyzing the texts of 14,270 National Bureau of Economic Research (NBER) WPs published during 1999-2016. We conduct five sets of analyses. First, we compute the aggregate appearance frequency of the term 'crisis/crises' in the WPs and correlate it with the index of economic stability. Second, we construct the time series of the \% of WPs with the term 'crisis/crises' in the period 1999-2016 for each NBER program. Third, we employ the Latent Dirichlet Allocation (LDA) method of Blei et al. (2003) and Griffiths and Steyvers (2004), to quantify the frequency of the appearance of crisis-related themes/words in the WPs, and measure associations between them. We apply LDA to the abstracts of the WPs, to identify crisis topics, and assess the changes in the weight of each topic over time. Fourth, we study the degree of engagement of the scholars of each program in studying the different topics. Fifth, to assess the effect of the crisis on the study of crisis topics and as an additional analyses, we apply the LDA method also to the crisis WPs only, which are the WPs that primarily focus on financial crisis. 
Although the NBER WPs do not go through a blind review process like regular journal articles, they nevertheless offer several advantages. First, the WPs are published and circulated faster than journal articles. Second, NBER affiliates form a large group of highly influential leading scholars, many of them very senior in the discipline. Third, the NBER affiliates form a highly diverse group, specializing in various fields of economics and finance. Fourth, the WPs are free from journal-type editorial management and intervention. Finally, the WPs are widely circulated and cited. We believe therefore, that NBER WPs are particularly useful and relevant for answering the questions we pose.

Our findings are as follows. As a whole, the NBER research community was barely engaged in studying financial crisis before 2008, but its reaction to the crisis was fast and intense. The $\%$ of WPs with the word 'crisis' increases from 8\% in 1999-2007 to 14\% in 2008-2016, on average. Moreover, the weights of the crisis topics identified by the LDA algorithm are almost tripled in the post-crisis period.

We also find that the volume of crisis-related WPs is counter-cyclical and lags financialinstability indexes. A regression analysis of the annual frequency of the WPs with the word crisis and the two-year lagged index of Composite Indicator for Systemic Stress (CISS) in the financial system, yields a positive and statistically significant relationship. Moreover, the predicted level of the NBER community engagement in 2015-2016 are below the actual level, suggesting inertia in the study of crisis in the post-crisis period. Further, the actual data fall below the regression line in 2006 and 2007, pointing at the low engagement of the community before the crisis period.

We find however, that in the post-crisis period all relevant NBER programs increased significantly their engagement. The International Finance and Macro program members were engaged in the study of crisis before the crisis, and structural breaks were not observed. The Monetary Economics program had a low engagement before the crisis, but became very active in the post-crisis period, converging with the efforts of the International Finance and Macro program. The members of the Asset Pricing and the Corporate Finance programs, hardly refer to "crisis" in the pre-crisis period. However, as the crisis develops, their study-efforts of crisisrelated issues increase most aggressively in comparison to other programs.

LDA analysis identifies 9 crisis topics (out of 500 considered) in the abstracts of the WPs published between 1999 and 2016. These are 'International Reserves,' 'Sovereign Debt,' 'Repo and Securitization,' 'Liquidity,' 'Emerging Markets,' 'Global Crisis,' 'Great Recession,' 


\section{'Sudden Stops,' and 'Financial Intermediaries.'}

We find that the topic of 'Emerging Markets,' typically identified with a crisis in small open economies, became uninfluential in the post-crisis period. Similarly, the topic of 'Sudden Stops,' which concerns the macroeconomic adjustments needed to deal with a sudden reversal in the net capital inflows, had also disappeared. These topics were studied mainly by the members of the International Finance and Macro and Economic Fluctuations and Growth programs.

Two new topics emerged as a result of the crisis. The first deals with 'Repo and Securitization,' a natural candidate for causing the crisis as such instruments did not exist in previous crises. It is mainly studied by the Asset Pricing and Corporate Finance programs, which were almost uninvolved in crises-studies before 2008, and by the Monetary Economics program. This topic is almost ignored by the International Macro and Finance program, the most active program in studying financial crises before 2008. There is a sharp decline in the study of the topic from 2013 and on. The second topic that emerged in the post-crisis period is 'Great Recession,' which relates to the spread of the financial crisis to the real economy and its effects on different aspects of the economy. In contrast to the other crisis topics, we find a persistence in the study of the topic of 'Great Recession.' Indeed, the topic's weight increases also in the postcrisis period of 2013-2016.

'Liquidity,' 'International Reserves,' and 'Sovereign Debt' are pro-cyclical. Similar patterns are observed for the topic of 'Financial Intermediaries,' which deals with the structure of the financial sector and financial institutions while focusing on the task of regulators, and for the topic of 'Global Crisis.' The latter focuses on how financial crisis spread across markets and countries. While the topic received almost no attention before the crisis, it became the lead topic among all economics topics in the post-crisis years. In contrast to all other topics (which typically capture the attention of one or two research programs), the topics of 'Global Crisis' and 'Financial Intermediaries' drew attention from multiple program members in the post-crisis period, consistent with the assessments of Goldstein and Razin (2015).

When we match the crisis topics with the NBER programs, we find that the International Finance and Macro program members were engaged in the study of crisis before 2008, but they abandoned the research topics of 'Sudden Stops' and 'Emerging Markets' in the post-crisis period, shifting their focus to 'International Reserves' and 'Sovereign Debt.' In contrast, the members of the Asset Pricing and Corporate Finance programs, who were not engaged in the 
study of crisis before 2008, began studying new topics 'Repo and Securitization' and 'Liquidity.'

To understand how the crisis literature evolved over time, we identify 'crisis WPs,' i.e., the NBER WPs with a primary focus on the financial crisis and conduct two LDA analyses. In the first analysis, we conduct an LDA topic analysis of the crisis WPs. While we find significant differences in the average weights of 5 topics (out of the 20 topics considered) between the precrisis period (2005-2008), and the crisis period (2009-2012) or the post-crisis period (20132016), there is no single topic with a significant difference between its weight during the crisis period (2009-2012) and the post-crisis period (2013-2016). These results are indicative of a significant change in the crisis studies brought about by the 2008 crisis, and of a stability in the crisis study practices and interests in the post-crisis period.

In the second analysis, we study separately the topics for the pre- and post-2008 crisis period. We find several differences between the two periods. First, a topic that makes a first-time appearance only in the post-crisis period is 'Fiscal Union and European Union.' Second, consistent with the analysis of the entire NBER WPs, the topic of 'Sudden Stops' stops suddenly, leaving the stage. Third, the topic of 'Monetary Policy' in the post-crisis period does not relate to such words as 'currency,' 'exchange,' and 'emerging.' Instead, the topic now refers to 'central bank' and its activities. Finally, two new additional topics are 'Great Recession' and 'Repo and Securitization,' in relation to the ways of achieving economic recovery and growth, and to the activities of the Federal Reserve.

The paper is organized as follows. In section 2, we discuss textual analysis in economics. In section 3, we describe the data and the methods. In section 4, we study the frequency of the word 'crisis/crises' in NBER WPs, followed in section 5, by an analysis of its variability across NBER programs. In section 6, we describe the LDA algorithm for topic modeling, and identify the crisis topics in the NBER WPs. In section 7, we present a meta-study to assess how the engagement in the different crisis topics evolved over time. In section 8, we match crisis topics with research programs to identify subfields that led the study of new research topics or abandoned old research topics. In section 9, we focus on the crisis WPs only, and assess the effect of the 2008 crisis on the studies they report. We conclude in section 10 .

\section{Textual Analysis and the Study of Financial Crisis}

In recent years, LDA topic modeling technique has become a popular method for analyzing 
textual data in economics. ${ }^{2}$ We use the LDA to study the evolution of the crisis study around the 2008 financial crisis. Our paper is related to two strands in this literature. The first are studies that use a topic modeling to understand the effects of the financial crisis on policy making. Examples include the analyses of the transcripts of the FOMC meetings, or the transcripts of the meetings of the governing boards of central banks. The second are studies that analyze the contents of economic journals and the trends therein over time. We combine the two by studying the effect of the 2008 financial crisis on the economic literature using the LDA.

Studies of texts in the context of economic and financial crises include Shirota (2016), who identifies and extracts topics concerning the 1997-1998 Asian financial crisis. Fligstein et al. (2017) analyze the Fed's FOMC meeting minutes to understand why the committee members failed to see the coming of the 2008 crisis. Hansen et al. (2018) also apply the method to the Fed's FOMC meeting minutes, to study how transparency affects the monetary policy-makers' deliberations. Keida and Takeda (2018) apply the method to analyze the transcripts of the pressconferences of the governors of the Bank of Japan. Larsen and Thorsrud (2019) employ LDA to quantify media narratives related to business cycles in the US, Japan, and EU. ${ }^{3}$

The second strand of the literature is composed of several recent papers that study the content of economics journals. Kosnik (2017) assess the distribution of journal pages between micro and macro. Angrist et al. (2017, 2019) use LDA to assess the impact of economics scholarship on other disciplines. Wehrheim (2019) analyses the topics of the articles published in the Journal of Economic History. Goldstein et al. (2019) try to understand the topics of "FinTech" by analyzing the abstracts of 156 proposals submitted to a special issue of Review of Financial Studies. Bowles and Carlin (forthcoming) use LDA topic modelling to explore the evolution of the content of introductory economics textbooks.

A recent WP by Aigner et al. (2019) is perhaps the most relevant in the context of our paper. Aigner et al. analyze top-cited economic papers before and after the 2008 financial crisis based on the papers' keywords, and find that the term 'financial crisis' only had a marginal presence in

\footnotetext{
${ }^{2}$ Lüdering and Tillmann (2018), Athey and Imbens (2019), and Gentzkow et al. (2019) survey the methods applicable to the analysis of textual data with applications in economics and finance.

${ }^{3}$ A large related literature studies the communication strategies of the Fed and of the FOMC, and their effects on markets, by analyzing the contents of the FOMC minutes, the Fed's announcements, etc. See, for example, Born et al. (2010), Boukus and Rosenberg (2006), Cecchetti (2003), Cukierman (2009), Ehrmann and Fratzscher (2005, 2007, 2009), Ehrmann et al. (2019), Hansen and McMahon (2016), Kansoy (2019), Kryvtsov and Petersen (2019), Poole (2005), Romer (2010), Shiller (2017), Thornton (2006), Jansen and de Haan (2011), and Woodford (2005). Blinder et al. (2008) survey the earlier studies in this literature.
} 
the pre-crisis years, but in the post-crisis years, the relative frequency of the term quadrupled. However, they find that the crisis has not led to substantial changes in the way economists view the financial markets. Overall, therefore, they find a stable topical orientation.

Our study differs from theirs in several important ways. First, we ask how the crisis-related literature evolved around the 2008 crisis. Aigner et al (2019) in contrast, consider the effect of the crisis on the entire economics research. Second, we use a topic modeling algorithm to analyze the WPs, as in Kosnik (2015) and Angrist et al. (2017), and thus we do not limit our analyses to a small number of keywords chosen by authors, as Aigner et al. (2019) do. Third, we consider different fields and subfields of economics and their contribution to the study of crisis overtime across different topics. Finally, we study the texts of NBER WPs, which are unaffected by editorial policies and preferences and, unlike journal papers, are published with no delay.

More importantly however, and counter to the findings of Aigner et al. (2019), we find a significant change around the crisis years in the study of almost all crisis-related topics. In addition, we identify several new topics that have emerged in response to the crisis, and several old topics that have disappeared in response to it. Moreover, we offer evidence on the way the academic reaction varied across different subfields of economics.

\section{Data: the NBER Working Papers}

Our primary data consist of the 14,270 WPs published by the NBER during 1999-2016. NBER, a private, non-profit leading academic think-tank, is based in Cambridge, MA. ${ }^{4}$ Over 1,400 professors from universities and colleges in North America, have NBER affiliations.

NBER activities are organized around 20 research programs and 13 working groups, each specializing in a particular filed, and holding an annual meeting. ${ }^{5}$ In addition, NBER holds a Summer Institute, hosting several dozen workshops during a three-week period. ${ }^{6}$

One of the main NBER activities, however, is the WP Series, a highly influential series of studies authored by the NBER affiliated faculty, covering different fields and subfields of economics and finance, and studying a wide range of topics and issues. The WPs are grouped

\footnotetext{
${ }^{4}$ Detailed information on NBER and its activities can be found at: https://www.nber.org/.

5 The list of the NBER programs and working groups can be found at https://www.nber.org/ $\rightarrow$ Activities.

${ }^{6}$ For example, during the Summer Institute 2019, 52 workshop were held from July 8, 2019 to July 26, 2019. For the list of the workshops, see https://conference.nber.org/conferences/2019/SI2019/SI2019 rev.html.
} 
according to the 20 working programs, and they are circulated and distributed widely. ${ }^{7}$

We choose to study the NBER WPs for several reasons. First, they offer a speed of knowledge dissemination far higher than the traditional academic journals because of the slow review process on which journal editors rely. Indeed, according to Krugman (2013), the function of NBER WPs is to get research out as soon as possible so other economists can discuss it.

Second, the NBER WPs are highly influential, widely circulated and frequently cited. For example, according to IDEAS/RePEc (the largest bibliographic database of economics research), the NBER WP series rank first (Technical WPs included), among the 2,235 WP series included in the ranking. ${ }^{8}$ NBER WPs rank first also based on the $h$-Index, with the index value of 350 and a total of 865,620 adjusted citations. The CEPR Discussion Papers rank second, with an $h$-Index of 221 , and a total of 310,301 adjusted citations. ${ }^{9}$

Third, with over 1,400 affiliates, NBER is one of a kind community of academics. The volume of the output produced by the NBER members is extraordinary. Indeed, based on the number of WPs, the NBER WPs series tops the list of the WP series, when we consider all the single-source WP series. According to IDEAS/RePEc, the NBER WP series include 26,223 WPs (including the Technical WPs), followed by CEPR Discussion Papers with 13,635 WPs. ${ }^{10}$ Figure 1 plots the time series of the total number of NBER WPs published annually, from 1999 to 2016. According to the plot, there was a sharp increase in 2001 in the number of the WPs published, from about $200 \mathrm{WPs} / \mathrm{year}$ to about $700 \mathrm{WPs} /$ year, and it has been increasing since then.

Fourth, the NBER affiliates are leading scholars, specializing in different areas of economics and finance. Many are senior figures, often in charge of editing, coediting, or managing the disciplines' premiere journals. Indeed, according to Krugman (2013), "In many sub-fields of economics, just about anyone well-known in the profession is an NBER research associate." 11

Fifth, the NBER WP series are produced by highly diverse group of scholars, without any

\footnotetext{
${ }^{7}$ The list of the WPs by research programs can be found at: https://conference.nber.org/papersbyprog/.

${ }^{8}$ Some of the WP series included in this ranking are actually pre-prints of accepted and/or forthcoming papers, which are different from regular WPs because of the blind review process the latter have to go through. In the ranking cited above, the NBER WP series is actually ranked second after Princeton Papers, which is ranked first, but the latter is a series of accepted papers. See: https://ideas.repec.org/top/top.wpseries.all.html.

${ }^{9} h$-Index of a WP series is the number of WPs in the series with at least $h$ citations. The citation count figures are adjusted to exclude citations from the same WP series. See: https://ideas.repec.org/top/top.wpseries.hindex.html, column 2. For explanatory notes, see: https://ideas.repec.org/top/top.wpseries.hindex.html\#explain.

${ }^{10}$ See: https://ideas.repec.org/top/top.wpseries.all.html, column 2.

${ }^{11}$ According to the NBER, 29 Nobel Prize winners in Economics, and 13 past Chairmen of the President's Council of Economic Advisers have held NBER affiliations. See: https://www.nber.org/info.html.
} 
kind of journal-type editorial intervention, review, or guidance. Therefore, NBER WPs are relatively free from biases that journal editorial boards might have towards their preferred questions, methodology, modelling framework, empirical strategy, etc.

Additional advantage of the NBER WPs is their particular attention to policy-related issues. Indeed, according to Fabricant (1984, p. 2), the NBER's Director of Research from 1953 to 1965 , one of the guiding principles of the NBER from its establishment in 1920, was that "Its research should concentrate on determining facts, and the connections among facts, that are important in dealing with major problems of economic policy." 12

Descriptive statistics for the six NBER programs are presented on Table $1 .{ }^{13}$ During 1999 2016, the annual average number of WPs per program was 98.8. The largest program is Economic Fluctuations and Growth with 191.28 WPs/year, on average, and the smallest is Health Care (not shown), with 32 WPs. The activities of all programs increased significantly during the last few years. For example, the total number of WPs published annually increased from 199 in 1999, to a peak of 1,180 in 2013 (Figure 1). The average annual number of WPs per program had increased as well, from 71.1 before the crisis period 1999-2007, to 132.7 after the crisis period 2008-2016.

\section{Content Analysis}

The most basic notion in content analysis is the words' frequency because the words that are mentioned most often are presumably also the words that reflect the greatest relevance (Stemler 2000). Our starting point therefore, is the frequency of the word 'crisis/crises' in the WPs.

\subsection{Frequency of the Word 'Crisis/Crises' in the NBER WPs over Time}

We consider several measures of the words' frequency. First, we count the total number of times that the word 'crisis/crises' is mentioned in all NBER WPs annually. Second, to control for the changing size of the NBER community, we adjust the data for the number of WPs published annually, yielding the average appearance frequency of "crisis/crises" per WP. Third, we calculate the \% of the WPs that mention the word crisis annually. This helps us identify the WPs

\footnotetext{
${ }^{12}$ Despite this, the authors of the NBER WPs are expected “...to ascertain and present to the economics profession, and to the public more generally, important economic facts and their interpretation in a scientific manner without policy recommendations." Source: Amended and Restated By-Laws of NBER, Inc., Adopted April 28, 2014. See: https://www.nber.org/NBERByLaws.pdf, accessed June 11, 2019.

${ }^{13}$ In the appendix, in Table 1A, we present these figures for all 20 NBER research programs.
} 
that might relate to the crisis, and the WPs that completely ignore it. ${ }^{14}$

Figure 2a shows the total number of appearances of the word 'crisis/crises' in the first five paragraphs of the introductory sections of all NBER WPs. The frequency, as the figure shows, had tripled from 100 in 1999 to about 250 in 2002, remained at that level until 2005, and then dropped back. It increased again in 2006 and 2007, but in 2008, as the financial crisis began to unravel, it jumped sharply to 600, reaching the peak of 700 in 2011. By 2016 it was down at 500, but still twice as high as the pre-crisis average.

To control for the increase in the number of WPs, Figure $2 b$ plots the average number of appearances of the word "crisis," in the first five paragraphs of the introductory section, per WP. The average frequency was stable at around 0.40-0.42 from 1999 till about 2004, and then dropped to about 0.16 in 2006, suggesting that the discipline had lost interest in crises in that period. At this point the average frequency started to climb monotonically, reaching the peak of 0.70 in 2011. During the post-crisis period, the figure went back down to around 0.45 .

Figure $2 \mathrm{c}$ shows the $\%$ of crisis WPs, which we define as WPs that mention the word 'crisis/crises' at least once in the first five paragraphs of the introductory section. ${ }^{15}$ The \%, which stood on $10 \%$ in 1999 , decreased to $6 \%-7 \%$ during the pre-crisis years. In 2009, in the midst of the crisis, it jumped to $13.8 \%$, and continued climbing, reaching $17.8 \%$ in 2011 . It then went down, reaching a trough in 2015-2016, but still above the pre-crisis level, around 12\%-14\%. The plot suggests that the academic interest in crisis is counter-cyclical: the sharp increase in the number of crisis WPs occurs during the period of the great recession.

According to Table 2, the \% of crisis WPs averaged 8.3\% during the pre-crisis period, 19992007, and $13.5 \%$ during the post-crisis period, 2008-2016. The difference is statistically significant the $1 \%$ level with $z=9.95$. Moreover, according to Table 3 , the sup-Wald statistic attains its maximum value of 70.36 in 2009 , also significant at the $1 \%$ level.

\footnotetext{
${ }^{14}$ We should note two potential difficulties in the context of word frequency count. First, the use of synonyms can lead to an underestimation of the importance of a concept (Weber 1990). Indeed, there are several synonyms for the word 'crisis' such as a 'recession, 'financial turmoil,' 'market crash,' 'depression', etc. However, none of these synonyms are as strong and as charged as the word 'crisis,' as none of them encompass the entire set events and circumstances that are captured by the word 'crisis.' Second, some words may have multiple meanings. For instance "state" could mean a political body, a situation, or a verb meaning "to speak." Therefore, we also use LDA topic modeling in sections $6-8$ and in section 10 , to conduct robustness check to validate our results.

15 This somewhat arbitrary definition of a crisis WP is not fool proof, and thus we address it further below in section 8 and 9. However, if a WP fails to mention the word 'crisis/crises' even once, then arguably, it cannot be considered a crisis WP. Thus, our definition imposes a lower bound on the engagement of the WP author/s in the crisis study.
} 


\subsection{Crisis Study and Financial Instability Indexes}

To assess the correlation of the crisis study intensity with financial instability, we consider two indexes of financial instability. The first is the Kansas City Financial Stress Index (KCFSI), a monthly measure of stress in the U.S. financial system, based on 11 financial market variables (Hakkio and Keeton, 2009). The second index, Composite Indicator of Systemic Stress (CISS), is based on the aggregation of 5 market-specific sub-indices constructed from 15 individual financial stress measures of EU. The index puts a high weight on situations where stress prevails in several market segments simultaneously, capturing the idea that financial stress is more systemic and thus more dangerous if financial instability spreads widely (Holló et al. 2012).

We calculate annual averages of the two indexes to match the annual frequency of our data. Figure $3 \mathrm{a}$ and Figure $3 \mathrm{~b}$ indicate a high correlation between the $\%$ of crisis WPs and 2-year lagged CISS and KCFSI indexes, respectively. In other words, the number of crisis WPs lags the financial instability indexes. Indeed, the regression estimation results in column 1 of Table 4 are consistent with this interpretation. The slope and the intercept of the estimated regression are both positive and statistically significant at the $1 \%$ level with $\bar{R}^{2}=0.68$.

According to Figure 3c, which shows a scattered plot of the two variables, the predicted level of the academic engagement in the crisis study in 2015 and 2016 are far below the actual level, suggesting a persistency in crisis studies (predicted values of $8 \%$ and $9 \%$ vs. actual values of $13 \%$ and $14 \%$ respectively). Thus, there is "inertia" in the study of crisis in the-post crisis period. Moreover, the actual observations fall below the regression line in 2006 and 2007, pointing at the low engagement of the academic community before the crisis period.

We obtain similar results when we include in the regression a dummy variable for the post2008 period. The regression coefficients are still positive and significant at the $1 \%$ level with $\bar{R}^{2}=0.66$ (column 3, Table 4). When the CISS index is added to the regression, the estimated

coefficients are positive and significant at the $1 \%$ level with $\bar{R}^{2}=0.96$ (column 4, Table 4).

The 2-year lagged US index for financial stability, KCFSI, also has a positive and statistically significant relationship with the frequency of crisis WPs, but to a lesser extent than the European index. Here $\bar{R}^{2}=0.28$, which is significantly lower, and the slope of the regression equation is significant at the $5 \%$ level (column 2 of Table 4 ).

\section{Crisis and the NBER Research Programs}


The NBER research activities are organized into 20 programs, covering all major subjects in economics. ${ }^{16}$ We focus on six programs: Monetary Economics, International Trade and Investment, Corporate Finance, Asset Pricing, International Finance and Macroeconomics, and Economic Fluctuations and Growth. We choose these programs for several reasons. First, the topics of these programs cover are perhaps the closest and therefore most relevant for the study of financial crises. Second, the great majority of the Research Associates that are members in these programs, specialize in either monetary economics, macroeconomics, or finance, the subfields of economics that are most closely associated with issues related to financial crises. Third, these program members have produced the highest $\%$ of crisis WPs. ${ }^{17}$ Finally, they are among the largest NBER programs in terms of research output, and the number of members.

Out of the 14,270 NBER WPs that were published during 1999-2016, 1,632 of them, i.e. $11.4 \%$, are crisis WPs. The six programs noted above engage most extensively in crises study, in terms of both the absolute number and the \% of crisis WPs. The total number of WPs published by the members of these programs ranges between 1,977 and 3,634. Of these, between 189 (International Trade) and 737 (International Finance and Macroeconomics) are crisis WPs. The programs, however, differ in both, the intensity as well as the speed of their reaction to the crisis.

For each program, we run three tests to understand how the program' members were engaged in studying the crisis and how they have reacted to the crisis. First, we use $z$-test to compare the average \% of crisis' WPs written before and after 2008 (Table 2). Second, for each program we run a regression of the average annual \% of crisis WPs published by the program members, on the average annual \% of crisis WPs produced by all programs (Table 5). A regression coefficient of greater (less) than 1 suggests that the program is more (less) "active" in studying the crisis in comparison to the average of the entire NBER community. The intercept can be interpreted as the program members' efforts to study crisis when the rest of the community is not engaged in studying it. Third, we apply sup-Wald (Quandt Likelihood Ratio) test for identifying structural breaks (Table 3). The time series plot of the average annual \% of crisis WPs for eight NBER research programs (the above six programs, plus two more for reference), is shown on Figure 4.

Table 2 presents descriptive statistics on crisis WPs for the six programs. According to the

\footnotetext{
${ }^{16}$ In addition, there are 13 NBER working groups. The working groups are smaller than NBER programs, and they also tend to be more narrow-focused, often studying a single topic.

${ }^{17}$ We exclude from the list of the programs Developments of the American Economy because it specializes in a geographic region unlike other NBER programs.
} 
table, the members of the International Finance and Macroeconomics and Monetary Economics programs published the highest numbers of crisis WPs, 737 and 468, respectively, during the sample period. These are the only two programs that have an average \% of crisis' WPs, $29.6 \%$ and $11.9 \%$, respectively, that exceed the average of all NBER programs before the crisis, $8.3 \%$.

The crisis effect on the scholarly interests of the members of the International Finance and Macroeconomics program is small, but statistically significant. From 2008 to 2016, the average $\%$ of crisis WPs the program members published increased to from $29.6 \%$ to $36.9 \%$, with $t=$ $3.70, p<0.01$. According to Table 5, the regression of the annual \% of crisis WPs of this program, on the annual \% of crisis WPs of all NBER programs, yields a positive intercept of $15.2 \%$, significant at the $5 \%$ level. This suggests that this program members were engaged in studying crisis-related topics when all other programs were studying other topics. The slope estimate, 1.65, is low, but statistically significant at the $1 \%$ level.

In contrast, we observe a big change in the intensity of the Monetary Economics program members in the post-crisis period, averaging $31.6 \%$ crisis WPs after 2008 , compared to $11.9 \%$ before 2008. By 2016, the two programs, International Finance and Macroeconomics and Monetary Economics, converge to the same peak, $46 \%$ of the average $\%$ of crisis WPs, as Figure 4 indicates. In other words, by 2016 almost half of the WPs produced by these two research groups, had some crisis-related content. Using topic modelling analysis, however, we show below that there are important differences between the questions that the two program members ask and the particular topics they chose to study.

The Monetary Economics program is the most "counter cyclical" and aggressive in studying the crisis with a slope of 2.92, significant at the $1 \%$ level, relative to the average of the entire NBER community (Table 5). Nevertheless, the reaction of its members was relatively slow compared to the finance-focused programs. Indeed, according to Table 3, the sup-Wald statistic for a structural break in 2008 for this program is significant only at the $10 \%$ level $(p=5.58 \%)$. Also, according to Figure 4, it caught up with the International Finance and Macroeconomics program, in terms of its engagement intensity, only in 2011.

The members of two finance-related programs, Corporate Finance and Asset Pricing, had barely referred to crisis before 2008. The average annual frequency of crisis WPs published 
before 2008 by the members of these two programs, are $7.3 \%$ and $5.3 \%$, respectively. ${ }^{18}$

Moreover, these are the only two programs with negative and statistically significant intercept estimates, about $-11 \%$ in both cases, in the regression estimates in Table 5. While these program members seem to have been completely disconnected from the study of crisis related issues prior to the 2008 crisis, their reaction to it was the fastest and perhaps also most dramatic among all programs. The sup-Wald statistic attains its maximum value for the two programs in 2008. According to Table 2, the average \% of crisis WPs after 2008 equals 26.1\%, more than triple in comparison to pre-crisis period, for the Corporate Finance program. For the Asset Pricing program, it is $22.5 \%$, more than quadrupling in comparison to pre-crisis period. Moreover, Figure 4 shows that the two programs are still very active in studying the crisis, with a similar extent of engagement over time. The slope estimates in Table 5 equal 2.52 and 2.3 for Corporate Finance and Asset Pricing programs, respectively, both significant at the $1 \%$ level.

Two programs, International Trade and Investment, and Economic Fluctuations and Growth, behave very similarly until 2012 (Figure 4). Prior to the crisis, both program members have a low engagement in crisis-related topics, but it jumps following the 2008 crisis. However, the two programs diverge in 2012. The members of Economic Fluctuations and Growth program seem to keep the same level of engagement, but the members of the International Trade and Investment program reduce their crisis-related study efforts to the pre-crisis levels.

Finally, looking at the last three years of our sample period, 2014-2016, in Figure 4, the Monetary Economics, International Finance and Macroeconomics, Corporate Finance, Asset Pricing, and Economic Fluctuation and Growth program members are still engaged in studying the crisis in the same intensity as in the period immediately following the crisis, 2009-2012. International Trade and Investment along with other programs, however, have reduced their efforts to study crises. See Table $2 \mathrm{~A}$ of the Appendix.

\section{Topic Modelling Using LDA}

Topic modelling algorithms are designed to approximate what happens in human brain when we read and interpret texts. ${ }^{19}$ Machines cannot do this on their own, we need to teach them. This

\footnotetext{
${ }^{18}$ As an illustration, only 4 WPs out of 86 WPs published in 2007 by the Corporate Finance program, mention the word "crisis." Even more extreme, only one WP out of 92 WPs published by the Asset Pricing program in 2007 mentions the word "crisis."

${ }^{19}$ For example, humans can tell apart the different meanings of the word fair based on the context, such as in (1) it is not fair, (2) the school held a book fair, (3) the weather is fair, and (4) he did a fair job under the circumstances.
} 
is done by feeding the machine with input, i.e., texts.

Topic modelling algorithms take as input textual information, for example documents, treating them as a bag of interchangeable words where syntax rules play no role. The algorithms identify the topics in the documents and produce a list of words found in the documents that form a given topic. In other words, the algorithms take texts, and break them down into lists of words, such that the words in each list are related to each other, and each list forms a topic. The algorithms assign to each word the probability of how likely it is to appear in the context of the given topic. The resulting model consist of the topics, the words, and the context, which is viewed as approximately resembling the human brains' interpretation of textual information.

The algorithms use words' statistical co-occurrence patterns to produce a group of related words, which form a topic or a theme. A word can belong to many topics. The importance of each word is determined relative to other words in the topic, and thus the occurrence frequency of each word in a topic is ranked relative to the occurrence frequencies of other words.

Topic modelling algorithms assume that words in a given text are related. In our case, NBER WPs are usually addressing few research questions and thus their texts are highly contextualized. The algorithms assume also that a given text/document contains multiple topics, where a topic is defined as a distribution over a fixed vocabulary of terms. For example, if NBER WPs cover $K$ topics, then we can assume that each WP covers these topics with different proportions. This seems reasonable because NBER WPs are quite heterogeneous, and therefore we can think of them as combining a subset of themes that are found in all NBER WPs. In other words, in topic modelling, we think of a document as a probability distribution over topics, and we think of a topic as a probability distribution over words. The model's goal, therefore, is to simultaneously estimate the word content of each topic, and the topic content of each document.

As an example, suppose that we have a set of $D$ documents (WPs) that consist of a total of $W$ different words, and consider a matrix whose elements are the probabilities that word $w_{i}$ is present in document $d_{j}$. By breaking down the document texts into $K$ topics, the algorithm produces two probability matrices. The $(i, k)^{\text {th }}$ element of the first matrix is the probability that word $w_{i}$ is present in topic $k$. The $(k, j)^{\text {th }}$ element of the second matrix is the probability that topic $k$ is present in document $d_{j}$. 
More formally, topic modelling algorithms model the probability that word $w_{i}$ is present in document $d_{j}$ as a product of two probabilities. The first is the probability that word $w_{i}$ is present in topic $k, P\left(w_{i} \mid z_{i}=k\right)$. The second is the probability that topic $k$ is found in document $d_{j}, P\left(z_{i}=k \mid D=d_{j}\right)$. In other words, the algorithm assumes that

$$
P\left(w_{i} \mid D=d_{j}\right)=\sum_{k=1}^{K}\left[P\left(w_{i} \mid z_{i}=k\right) P\left(z_{i}=k \mid D=d_{j}\right)\right]
$$

where $P\left(w_{i} \mid D=d_{j}\right)$ is the probability distribution of words in document $d_{j}, P\left(w_{i} \mid z_{i}=k\right)$ is the probability distribution of words in topic $k$, and $P\left(z_{i}=k \mid D=d_{j}\right)$ is the probability distribution of topics in document $d_{j}$.

To classify the NBER WPs into different topics, we employ Latent Dirichlet Allocation (LDA), perhaps the most common algorithm used today for topic modelling. We use MalletLDA, a popular Java implementation for LDA. LDA assumes that the two probability distributions (probability distribution of words in topics and the probability distribution of topics in documents) are multinomial. Each distribution is drawn from a Dirichlet distribution, a multivariate extension of Beta distribution, which allows the estimates of $P\left(w_{i} \mid z_{i}=k\right)$ and $P\left(z_{i}=k \mid D=d_{j}\right)$ to be updated iteratively (Blei et al 2003, Steyvers and Griffiths 2007, Blei and Lafferty 2009, Fligstein et al 2017, Jegadeesh and Wu 2016, and Knispelis 2016).

The LDA algorithm proceeds as follows. First, it chooses random words from different documents, forming "initial topics." Next, the algorithm proceeds iteratively through each word in each document and estimates the influence of each word on each topic, by assessing the corresponding probabilities, as noted above. One of the assumptions in this process is that all the other words in the topic are correct, besides the current word. The algorithm will reassign the current word to a topic depending on the estimated correlation with and without the word.

To implement an LDA algorithm, three inputs are needed. The first is the number of topics, which the model has no way of determining on its own. By choosing the number of topics $K$, we are "forcing" the algorithm to identify $K$ topics in the text. The other two inputs are hyperparameters $\alpha$ and $\beta$, both parameters of Dirichlet distribution. The parameter $\alpha$ governs the 
prior topic distribution per document, while the parameter $\beta$ governs the prior word distribution per topic, controlling for the expected density of words in topics. High (low) $\alpha$ will lead to many (few) topics per document. High $\beta$ yields topics with words that contribute more uniformly to topics, while low $\beta$ will lead to few words dominating a topic. This implies, for example, that high $\alpha(\beta)$ will make documents (topics) appear more similar to each other because it makes every topic appear in every document, while low $\alpha(\beta)$ will make documents (topics) appear more distinct from each other because it will make every document be represented by fewer topics. ${ }^{20}$

To apply the LDA topic modelling algorithm, the raw textual data - the NBER WPs, had to be pre-processed and cleaned to remove all the "irrelevant" information, i.e., all possible sources of "noise." We follow the steps outlined by Fligstein et al. (2017, p. 11), as described below.

First, we downloaded the WPs from the NBER website, and converted them from PDF format to a Text format. Second, we filtered out of the text files the paper titles, the author/s names and other author-related information, the page numbers, graphs, equations, references, etc., keeping only the primary text. We had to repeat this process several times with different filtering instructions, because different WPs have different layouts and patterns. Third, we removed from each file, all the text except the first 5 paragraphs of the introduction. ${ }^{21}$ Fourth, we removed from the 5-paragraph texts, the "stop words" ("is," "the," etc.). In addition, we used a word-stemmer to remove any generic suffixes from the words, which enabled us to group them into similar word groups, when running the algorithm. Fifth, we combined different spellings of a given term such as "crisis" and "crises," into a single word - "crisis." Note that the first three steps apply only to the second part of our study, where we analyze the contents of the body of the WPs (section 9), rather than their abstracts (section 6).

The model starts by assigning to each word a generic label, based on their appearance in the text. Next, the model combines the context (WPs), the words that remain after pre-processing, and the topics, producing a topic distribution, i.e., what topics appear in the documents. The

\footnotetext{
${ }^{20}$ For more details about LDA and its implementation, see Jegadeesh and $\mathrm{Wu}$ (2016), who apply the method to analyze the minutes of the FOMC meetings.

${ }^{21}$ This choice was based on our belief that the WPs' introductory paragraphs will usually contain all the topic-related statements and thus words. Robustness analyses we run suggests that relying on the first 5 paragraphs is indeed sufficient.
} 
algorithm sorts the words and ranks them based on their appearance frequency by computing for each word a probability that it will belong to a topic. Because the labels the algorithm assigns to the topics, Topic 1, Topic 2, etc., are meaningless, we replace them with a more meaningful labels, based on the topic's content, based on the list of the words in the topic.

We programmed these steps in a special Python module, which automated the entire process. We cached the results of each step which made it easier to run the analyses many times, and to monitor the process to ensure that the results were reliable and optimized. After implementing these preliminary steps, the database was ready for processing using a topic-modeling algorithm.

As noted, we had to choose three parameters. It turns out that a reasonable number of topics in the first part of the analyses is $K=500$. We set $\alpha=0.01$ and $\beta=0.01$, which were also the default values of the LDA implementation we employed. The choice of $\beta$ was made based on the recommendations of the existing studies (Stayvers and Griffiths 2007, Paul and Girju 2009, Fligstein et al. 2017, Jegadeesh and Wu 2016, and Knispelis 2016).

To assess the sensitivity of the results to the parameter choices, we explored other possible values for $\alpha$ and $K$. See Table 6 . The figures in the table are the number of crisis' topics that the algorithm identified for each combination of $\alpha$ and $K$. As the table indicates, an increase in number of topics $K$, increases the number of crisis' topics the algorithm identifies. However, it turns out that any additional crisis' topics beyond 9, are either irrelevant or indistinguishable from the first 9 topics. We have therefore settled on $\alpha=0.01=1 \%$ and $K=500 .{ }^{22}$

We identify crisis WPs by looking for the word "crisis." Using the LDA algorithm, we identified 9 crisis topics. Table 7 presents top-10 words in each topic. The title we gave to each topic are based on the words that appear with the highest frequency in the topic. ${ }^{23}$ The 9 topics are labeled "International Reserves," "Sovereign Debt," “Liquidity," "Emerging Markets," "Repo and Securitization," "Global Crisis," "Great Recession," "Sudden Stops," and "Financial Intermediaries." To confirm that the topics indeed deal with the crisis, we checked that the word 'crisis' is actually mentioned in the 20 papers with the highest probability for each topic. Out of the 180 papers that we review, 178 papers mention the word crisis at least once. The full list of

\footnotetext{
${ }^{22}$ Jegadeesh and $\mathrm{Wu}(2016)$ report a similar figure. In analyzing their data, they settle on 8 topics, after conducting a similar sensitivity analysis.

${ }^{23}$ In case of synonyms, we add up the frequencies based on one representative word. For example, 'intermediaries' summarizes the words 'bank,' 'institutions,' 'sector,' and 'intermediaries,' which together appear more frequently than the second most frequent word in the topic - 'market.'
} 
these papers is given in Appendix B.

\section{Meta-Study of Crisis Topics}

To assess how scholars dealt with the crisis, we focus on the 9 crisis topics that we have identified, and examine the discipline's treatment of the topics in terms of the amount of the attention the topics received, and how that attention varied over time, particularly around the crisis' years. We also try to determine whether the evolution of the crisis topics was a stable processes, or perhaps it experienced changes. We describe the methods of our analysis in Section 7.1, followed by a discussion of the findings in Section 7.2.

\subsection{Topics' Rank and Structural Breaks}

To assess the effect of the 2008 crisis on crisis topics and their trends, we look at 9 time series that show the weight of each crisis topic in the NBER WPs' abstracts. We find that the behavior of the sum of the weights of all topics (Figure 5), is similar to the \% of crisis WPs (Figure 2c).

Figure 6 shows the average weight of each crisis topic between 1999 and 2016. We analyze the trends in three ways. First, Table 8 shows the annual rank of each topic among the 500 topics that were considered by the LDA algorithm. Second, to determine whether the evolution of the topics has followed a stable processes over time, or perhaps experienced a break, we use QuandtAndrews sup-Wald test for structural breaks, which is particularly useful in settings with unknown break points. ${ }^{24}$ To apply the method, we choose $15 \%$ symmetric trimming from both ends of the sample $(0.15 T<T B<0.85 T)$. We also calculate the Wald statistic for the years 2007, 2008, and 2009 to test for a known structural break during the period of the financial crisis. ${ }^{25}$

Finally, we use $z$-test to compare the average \% of crisis WPs written before the crisis (20052008), during and immediately after the outbreak of the crisis (2009-2012), and during the post crisis period (2013-2016). We interpret a positive or a negative significant $z$-test statistics as an evidence of the effect of the crisis on the importance of a topic. We can identify the "persistence" in the study of a topic if the $z$-test statistic is positive and significant between both the pre-crisis

\footnotetext{
${ }^{24}$ The sup-Wald test for structural breaks is based on Quandt's (1960) sequential application of the traditional Chow test for an unknown breakpoint. The test, known as the Quandt-Andrews sup-Wald test, is based on computing Wald test statistic for each of the possible breakpoints within a range of dates, and then finding their supremum. Hansen (1997) generates the approximate $p$-values for the sup-Wald statistic. See also Andrews (1993).

${ }^{25}$ Because of the trimming, structural breaks that occur in the proximity of the end points, 1999-2002 and 2014-2016, cannot be detected.
} 
and the post-crisis periods, and between the pre-crisis period and the crisis period. Similarly, a sign of "reversal" or no evidence for persistence is identified by an insignificant $z$-test statistics between the pre-crisis and the post-crisis periods, and a positive and significant $z$-test statistics between the pre-crisis and the post-crisis periods.

\subsection{Trends in Topics over Time}

Here we consider the evolution of the crisis topics over time and assess the effects of the 2008 crisis.

\subsubsection{General Trends}

Based on the ranking of the crisis topics, we classify the 9 topics into three groups. One group includes the emerging topic during the crisis period of 'Great Recession,' which is related to the spread of the financial crisis to the real economy. The second group of topics are the disappearing topics, 'Emerging Markets' and 'Sudden Stops.' The third group of topics are topics in which the crisis has only short positive effect on their weights. These topics include 'Financial Intermediaries,' that deals with the structure of financial markets and institutions that make them fragile, 'Liquidity, ' which deals with both market dry out and liquidity traps, 'Repo and Securitization, ' which deals on the effect of short term liabilities backed by risky portfolio of loans and bonds, 'Global Crisis,' which related to the global spread of local crisis and 'International Reserves, ' and 'Sovereign Debt.' Interestingly, there is a decline in all crisis' topics from the end of 2013 and on, except in 'Sovereign Debt' and 'Great Recession,' which remain relatively flat in the post-crisis period.

The effect of the crisis on each topic can be seen through the plots in Figure 7 and Tables 10, which shows the time series of the Wald-statistic for a structural break for each topic. The results indicate that all topics except 'Emerging Markets,' experienced statistically significant structural breaks during the sample period. Moreover, with the exception of 'Sovereign Debt,' all breaks occur either during the 2007-2009 financial crisis, or thereafter. All breaks with the exception of 'Sudden Stop' and 'Sovereign Debt,' are followed by an increase in the topics' weights (See Figures and 6 as well as Table 8).

The topics of 'International Reserves' and 'Global Crisis' experience the most significant breaks in 2009 according to the sup-Wald test. In 2007, our LDA model ranks the topics of “International Reserves" and 'Global Crisis' at 181 and 218 out of 500 (Table 8). However, at 
2009 the two topics are ranked at 53 and at the $1^{\text {st }}$ place respectively. The increase in the importance of the topic of 'Global Crisis' is also captured by a positive significant difference between the means of the pre-crisis period (2005-2008) and the crisis period (2009-2012). There is no significant difference in means for the same periods for the topic of "International Reserves", which can be explained by the decline in the importance of the topic since 2012.

The first structural break during the crisis period occurs in 2008 for "the topic of "Liquidity." In 2007 the topic was ranked at 202 and in 2008 at 72 . Similar to the topic of "International Reserves" there is no persistency in studying this topic and in 2012 the topic is ranked at 145. The topic of "Great Recession" experiences the first significant structural break only in 2009 based on Wald test and in 2010 based on sup-Wald test. The topic is ranked at 241 in 2007 and at 19 in 2010. The topic of 'Financial Intermediaries' experienced most significant break in 2012 and moves from the $86^{\text {th }}$ place in 2007 to the $38^{\text {th }}$ place in 2012. However, in 2015 the topic is ranked at 179 and the weights converge to the pre-crisis levels.

\subsubsection{Sudden Stop in the "Sudden Stop"}

The term "Sudden Stop," coined by Calvo (1998) following the 1994 Mexican crisis, describes situations where there is a sharp reversal in the aggregate foreign capital inflows. While there is no consensus on what triggers such reversals, two consequences have been amply documented - exchange rate drops and economic downturns, effectively constricting domestic consumption smoothing. Moreover, sudden stops typically come in clusters: the 1994 Mexican crash triggered a sudden stop in Argentina in 1995. In 1997-1998, the East Asian crisis engulfed 7 neighboring countries.

Macroeconomists' efforts to develop models that could explain sudden stops followed. According to Claessens and Kose (2013), these models tend to focus on the role of international factors, as captured by changes in international interest rates or spreads on risky assets, in causing sudden stops in capital flows. These models can explain the current account reversals, as well as the real exchange rate depreciations typically observed during emerging market crises.

In 2000, our LDA model ranks the topic of "Sudden Stop" at 450 out of 500 (Table 8). In the following years, the topic receives a lot of attention, so much so that by 2004, it ranks 32 , the highest rank a crisis' topic attained in that year. While the topic was still ranked at 181 in 2008, it disappears in the post-crisis period, ranking at 477 by 2009. Consistent with these variability in the ranking, we observe two significant structural breaks. The first in 2004, when the topic 
reaches its peak, and the second in 2007, when it starts to disappear from the literature. ${ }^{26}$ Moreover, as shown in Table 9, the topic of 'Sudden Stop' is the only topic in which a significant negative $z$-test at the $5 \%$ is observed between both the pre-crisis period and the crisis period and between the pre-crisis period and the post crisis period.

\subsubsection{A Reversal in the Study of 'Repo and Securitization'}

The financial crisis led many prominent scholars to suggest new study directions to cope with the ongoing crisis and prevent future crisis. One natural candidate that was viewed as amplifying the financial crisis, was the use of short-term debt instruments such as repo agreements and asset-backed-commercial papers (ABCP), to finance securitized long-term debt. These types of transactions were considered a likely culprit in fueling the crisis because such instruments were almost non-existent during the previous crises, and there was an explosive growth in their usage in the years prior to the 2008 crisis. Gorton and Metrick (2012b) suggest that securitization was a major channel for the fast growth of the "shadow banking" system. The increased vulnerability of the system came as a surprise to policymakers and economists, but understanding these instruments is critical for understanding the contagion that eventually spread to the real economy.

Indeed, our results show a significant structural break in 2009 for 'Repo and Securitization.' The Wald-statistic for the topic equals 39.1 (Table 10) and the rank of the topic shifts from the $423^{\text {rd }}$ place in 2008 to the $40^{\text {th }}$ place in 2009 ( $3^{\text {rd }}$ among the crisis topics in that year). The topic remains at the center of the academic research until 2012 , where it ranks $29^{\text {th }}\left(3^{\text {rd }}\right.$ among the crisis topics in that year). However, the interest in the topic declines fast in the post-crisis period, where the topic is ranked 371 in $2015 .{ }^{27}$ The robustness of the results are strengthened by the $z$ test for a difference in means. The average weight of the topic in the crisis period (2008-2012) is

\footnotetext{
${ }^{26}$ While explaining the reasons for the decline in the topic's importance is beyond the scope of our paper, according to Caballero (2010), the key concern before the financial crisis burst was that the US would experience a sudden stop in capital flows along with a sharp depreciation in the dollar, predictions which did not materialize. Mendoza and Yue (2012) propose a general equilibrium model which links sovereign default to business cycles and note that in most of the sudden stops' literature, the loss of credit market access is modeled as the result of an exogenous shock, whereas in their proposed model the exclusion from credit markets and the economic collapse are endogenous and influence each other.

${ }^{27}$ While there may be many possible reasons for the emergence of this research topic, including unregulated shadow banking system, moral hazard, too complex financial structures, and lack of transparency, we find in the literature only few explanations for its decline after 2012. Benmelech et al. (2012) show that adverse selection problems in corporate loan securitizations are less severe than commonly believed. Krishnamurthy et al. (2014) argue that the size of the repo market was too small to trigger a collapse in the financial system.
} 
significantly higher at the $1 \%$ level than in the pre-crisis period (2005-2008). However, the average weight of the topic in the post-crisis period does not differ significantly from the precrisis levels, and there is no evidence of persistence in the study of this topic.

\subsubsection{A Momentum in the Study of 'Great Recession'}

The topic of 'Great Recession,' which is related to the effects of the financial crisis on the real economy, hardly existed before the financial crisis, as it was ranked $414^{\text {th }}$ in 2008 . However, our results show a significant structural break in 2010 for the topic, where the Wald-statistic for the topic equals 12.6 (Table 10) and the topic is ranked $19^{\text {th }}$ among all topics in that year (Table 8). Moreover, the average weight of the topic in the crisis period is significantly higher than the weight in the pre-crisis period. The topic differs from the other topics that emerge during, and right-after the crisis, as there is a clear evidence of persistence in its research in the post-crisis period. The topic is ranked $6^{\text {th }}$ among all crisis topics in 2012 and 2014 (Table 8). Moreover, the average weight of the topic in the post-crisis period is higher than in the pre-crisis period, at a statistical significance of $1 \%$ (Table 9).

\section{Crisis Topics by NBER Research Programs}

How did the individual NBER research programs contribute to the study of crisis topics? For example, which program led the research on the new topic of 'Repo and Securitization?' and which programs were engaged in studying the disappearing topic of 'Sudden stop?' To answer these types of questions, we match the topics of the research with NBER research programs.

We proceed in two steps. First, we identify crisis WPs as we did above, but here we employ stricter criteria. We define a WP as a 'crisis WP' if (1) it includes the word crisis at least once in the first five paragraphs of the introduction, (2) crisis topics comprise at least $10 \%$ of the paper, and (3) crisis topics are among the top-three topics of the paper. Applying this definition, the algorithm identified 612 WPs, where 165 WPs were written in the pre-crisis period 1999-2007, and 447 in the post-crisis period 2008-2016.

Next, we add up the weights of each topic for the WPs of each programs, yielding matrices

where the $(i, j)^{\text {th }}$ element shows the sum of the weights of topic $i$ in the WPs of the research program $j$. By dividing each element by the total sum of weights of a topic (by summing up each row $i$, we obtain the $\%$ of each topic that belongs to each research program. For example, 5\% of the topic 'Sudden Stop' belongs to the WPs of the Monetary Economics program. 
Table 11 presents the results of the analysis for the 6 selected NBER programs. ${ }^{28}$ According to the table, the topics of 'Sudden Stop' and 'Emerging Markets,' that almost disappeared in the post-crisis period, were mostly studied by the International Finance and Macro program (62\% and $43 \%$, respectively) and by the Economic Fluctuations program (15\% and 16\%, respectively). In Appendix B, we show that all the 20 papers with the highest weight in this topic belong to the International Finance and Macro program, consistent with this finding. On the other hand, the International Finance and Macro program and the International Trade program are almost the only programs that were engaged in studying the topic of 'International Reserves,' (52\% and $17 \%$ respectively), a topic that drew a lot of attention in the post-crisis period. In Appendix B, we show that all the 20 papers with the strongest focus on this topic belong to these two programs.

The topic of 'Repo and Securitization,' which emerged after the crises, is mostly studied by the Corporate Finance program (37\%), Asset Pricing program (24\%) and the Monetary Economics program (17\%). Just $4 \%$ of the topic was studied by the International Finance and Macro program, and only $1 \%$ by the International Trade program. These results are confirmed by the analyses in Appendix B, where we show that all the 20 papers with the highest weight in this topic belong to one of the finance programs and none of them belong to the International Finance and Macro program. The topic of 'Liquidity', which reappears in the post-crisis period, receives an attention from the Asset Pricing program (32\%) and the Corporate Finance program (22\%). The International Finance and Macro and the International Trade programs are less engaged in this topic (11\% and $1 \%$, respectively).

In sum, the intensive activity of the International Finance and Macro program in the pre-crisis period was focused on studying 'Emerging markets' and 'Sudden Stop,' topics that mostly disappeared in the post-crisis period, 'International Reserves,' a topic that reappears in the postcrisis period, 'Sovereign Debt' and 'Global Crisis.' The intensive engagement of the financerelated programs in the post-crisis period was in studying 'Repo and Securitization,' a new topic, and 'Liquidity,' a reemerged topic.

\section{Crisis Literature: Pre-Crisis vs. Post-Crisis}

To further identify the effect of the 2008 crisis on the academic literature, we apply the LDA

${ }^{28}$ Table 11A in the Appendix, shows the results for the remaining NBER programs. 
method to papers that focus primarily on the crisis research. This analysis helps us understand if and how the structure of the crisis literature has been affected by the 2008-2009 crisis. Moreover, the analysis contributes to the robustness of the results that focuses on the effect of the crisis on the entire economic literature. Therefore, as in Section 8, we focus only on the 612 "crisis working papers."

We conduct two complementary LDA analyses, to study the change in the crisis literature. In the first analysis, we identify 20 topics in the 612 crisis WPs. We calculate the average weight of each topic in the pre-crisis period (2005-2008), around and during the crisis period (2009-2012), and in the post-crisis period (2013-2016). Similar to the analysis that is shown in Table 9, we use $z$-test to compare the average weight of a topic in the pre-crisis period with the average weight during the crisis and the post-crisis periods. In the analysis of the 500 topics which we discussed in Section 7, an increase in the weight of a crisis topic could be at the expense of the non-crisis topics. However, in the current analysis, an increase in the weight of a topic is at the expense of other crisis topics. The 20 topics and the words that belong to each one of them, as identified by the LDA algorithm, are presented in Table 7A in the Appendix. The weights of the topics as well as the results of the $z$-tests for mean differences between the periods are presented in Table 12.

Similar to the results of the analysis of the crisis topics which we report above for all the NBER WPs that are included in our database, we find that the topic of 'Sudden Stop' has a negative $z$-test statistic significant at the $1 \%$ level, when we compare between the pre-crisis and the crisis periods, as well as between the pre-crisis and the post-crisis periods. Thus, we see a drop in the study of the topic. A negative $z$-test statistic, significant at the $1 \%$ level, is also observed for the topic of 'Emerging Markets,' when we compare the period before the crisis and the crisis period, and the period before the crisis and the post-crisis period. Thus, consistent with the results of the analysis for the entire NBER WPs collection in Section 7, we see a persistent decline in the importance of these two topics.

We find a delayed reaction for two topics. The first is 'Fiscal and Monetary Policy.' The papers that belong to this topic primarily focus on the coordination of fiscal policy and monetary policy in the European Union (Table 7A in the Appendix). There is a positive and statistically significant difference between the average means of the pre-crisis and the post-crisis periods. The second topic of 'International Reserves,' which exhibits a significant drop in its average 
weight in the post-crisis period. The papers that belong to this topic, primarily focus on the accumulation of foreign reserves by China.

We find a positive and significant difference between the weights of "Great Recession" and "Repo and Securitization" in the pre-crisis and the crisis periods. However, similar to the results we reported in the analysis of the crisis literature using all NBER WPs in our database, we find here a positive and statistically significant difference between the pre- and post-crisis periods only for the topic of "Great Recession."

The comparison between the crisis and the post-crisis periods does not indicate any significant change in the weights of the topics. Thus, while the 2008-2009 crisis led to a structural break in the study of crisis-related topics, where the weights of 5 out of the 20 topics had significantly changed between the pre-crisis and the crisis periods, no such change is observed in the postcrisis period. Further, the topics that are related to the crisis, remain relatively stable. This conclusion is supported by the findings that, the average absolute change in the topics' weight between the pre-crisis and the crisis periods is only $2 \%$, and the absolute average change between the crisis and the post-crisis periods is only $1.4 \%$.

In the second analysis, we divide the crisis WPs into two groups. The first group includes the WPs that were written before the crisis (2005-2008), while the second group includes the WPs that were written after the crisis period (2009-2016). Here the LDA algorithm identified 10 topics for each group of WPs.

In Table 13, we present the topics using the labels we attach to them, along with the 10 most frequent words of each topic (out of 20), in the pre-crisis 1999-2007 period. In Table 14, we do the same for the post-crisis 2008-2016 period. Words that appear only in the pre-crisis or only in the post-crisis period, are indicated in italic. In the tables, the words of each topic are ranked according to their appearance frequency in the topic. For example, the word 'liquidity' appears 171 times as part of the liquidity topic in the pre-crisis period.

We find important differences between the two periods. First, a topic that makes a first-time appearance only in the post-crisis period is 'Currency Union' in the context of fiscal union and the European Union. Under this topic we find WPs that focus on the weaknesses of the European monetary union, and on the need for a robust common fiscal policy framework which could have 
alleviated the consequences of the crisis. ${ }^{29}$ While the EU is getting a lot of attention in the postcrisis period, the topics related to IMF and its restructuring program disappears from the postcrisis topics' list. This may be a reflection of the view that the institution is less relevant for a debt-crisis of large developed countries, as they may have easier access to more attractive lenders.

The topic of 'Sudden Stop' which refers to a situation where international capital inflows shrink in emerging markets, creating balance of payment crises, is another important topic that leaves the stage, stopping suddenly in the post-crisis $2008-2016$ period. ${ }^{30}$ This finding is consistent with the result we report in section 7, that sudden-stop models are mostly relevant in the context of foreign exchange management in small open economies, but not in the US or in a large currency union. Indeed, the topic of 'Monetary Policy' in the post-crisis period does not include such words as 'currency,' 'exchange,' and 'emerging.' Instead, the topic now refers to the 'central bank' and its activities.

Two new additional topics that enter the stage in the post-crisis 2008-2016 period, are 'Great Recession,' touching the ways of achieving economic recovery and growth, and the 'Federal Reserve,' whose activities now appear as a separate topic. While in the pre-crisis period the monetary policy is mostly focused on determining the short-term interest rates, in the post-crisis period the Fed implemented a quantitative easing program through purchasing long-term debt and risky assets from financial institutions. It is not surprising therefore, that the new topic refers now to the balance sheet of the Fed and to its responsibility in preventing a bank run.

The issues related to the activities of the central bank, relate also to the changing nature of the banking topics as a result of the crisis. In the post-crisis period, these refer to the short-term debt (repo) that were used to finance long-term mortgage-backed securities and other collateralized loans. These topics were not among the leading crisis' topics in the pre-crisis period.

\section{Summary and Conclusions}

The global financial crisis of 2007-2009 turned out to be the most serious economic crisis since the Great Depression. There is a consensus that the research community as a whole

\footnotetext{
${ }^{29}$ See, for example, Aizenman (2012), Bordo et al. (2011), Conesa and Kehoe (2014), Razin and Rosefielde (2012), and Vegh and Vuletin (2014).

${ }^{30}$ See, for example, Calvo (1998), Calvo and Mendoza (2000), Durdo and Mendoza (2004), Mendoza (2006, 2008), and Mendoza and Smith (2002).
} 
was not engaged enough in the study of the crisis before it occurred. In this paper, we use LDA topic modelling method, to offer quantitative measures of the nature and the intensity of the overall academic efforts to study and understand the crisis, as reflected in the 14,270 NBER WPS, published before, during, and after the crisis.

In doing so, we make three specific contributions. First, we assess the aggregate scholarly efforts by quantifying the intensity and the speed of the NBER scholars' response as the crisis was evolving. Second, we analyze the variation across NBER programs to assess which scholars in which fields and subfields of economics and finance have led the change. Third, we assess how the popularity of and the attention to different crisis-related research topics evolved over time, and how the different NBER groups were involved in developing and pushing forward these research agenda, topics, and ideas.

We find that the volume of crisis-related WPs is counter-cyclical, lagging financial instability indexes. The WPs written by Monetary Economics, Asset Pricing, and Corporate Finance program members of the NBER, hardly refer to "crisis" in the pre-crisis period. However, as the crisis developed, their study efforts of crisis-related issues increase rapidly, focusing on the links between 'Repo and Securitization' and the crisis. In contrast, WPs in macroeconomics programs refer extensively to "crisis" in the pre-crisis period. These WPs abandon the topics of "Sudden Stop' and 'Emerging Markets' with the crisis development and focus more on the topic of 'International Reserves.'

Overall, our findings are consistent with the critical arguments made by both the general public and the academics that some (but not all) macroeconomics and finance scholars, indeed failed to see the coming of the financial crisis. However, the results of our analyses suggest that as soon as the financial crisis began to unravel, the academic community responded quite dramatically to the crisis, and to the public criticism that the crisis has generated. Many academic economists and finance scholars, working in the relevant areas of research, stopped studying relatively less relevant topics, and switched their focus and efforts to studying and understanding the crisis, its causes and its consequences.

This endogenous response of the academic world to the 2008 financial crisis is counter to the popular perception and the public image of the academic finance and economics scholars, which argues that the academic economists are disconnected from real economies and that their scholarship has nothing to do with real life events and circumstances (see, for example, 
Georgalakis 2017).

This is also the conclusion of Reis (2018, p. 147): "Within days or weeks of the failure of Bear Sterns or Lehman Brothers, economists provided diagnoses of the crisis, and central banks and finance ministries implemented aggressive measures to minimize the damage, all of which were heavily influenced by economic theory. Economic concepts such as asymmetric information, bank runs, the role of liquidity, saturating the market for reserves, and forward guidance at the zero lower-bound, all provided concrete interpretations of the crisis, suggestions for policies, and discussion of trade-offs. The economy did not die, and a Great Depression was avoided, in no small part due to the advances in economics over many decades."

Our study has limitations, because of our primary focus on three questions_ “who, when, and how." The first question we ask is, who are the NBER scholars that study the crisis-related topics? To answer the question, we focus on the NBER research groups, and try to assess the research focus and the research agenda of each group.

The second question we ask is, when did the NBER scholars begin studying the crisis-related topics? To answer the question, we consider the pre-crisis period, the period when the crisis was still evolving, and the post-crisis period, and in each sub-period we characterize and document the scholarly efforts of the different NBER program members. The goal of these analyses is to identify the program members' timing in relation to the crisis, and say something about their lead-lag relationship, such as which program members led the efforts, which program members were more forward-looking, and which program members were more late comers.

The third question we ask is, how did the NBER scholar study the crisis-related topics? To answer the question, we identify the specific crisis-related topics the NBER members chose to study, which crisis-related topics got a particular attention, and what topics the scholars end up abandoning.

Given our focus on these three questions, we note two important questions which we did not address, and which future work should address. The first question future work should address is, "where," that is, where were the crisis-related topics studied? In the paper we focus exclusively on the NBER member scholars. While NBER scholars are leading scholars, there are other leading scholars, who are not affiliated with the NBER. We suspect that many of these scholars have also contributed to the crisis-related literature and to the crisis-understanding efforts. These include scholars at universities and colleges in many countries, scholars at central banks (such as 
at the research departments and at the financial stability divisions at Federal Reserve Banks, at the ECB, and at other countries' central banks), and scholars at research institutes and independent think tanks. The relevant work of all these and other scholars were excluded from our analysis.

The second question our study did not address is related to "why," that is, why some topics were studied but not others? Why did some topics emerge as central to understanding the crisis dynamics, while other topics were considered less important? While we briefly touch these points sporadically in the paper, we do not make a systematic effort of doing so, because the extent of the analyses that is required to answer these and related questions, would be beyond the scope of this paper. Some studies already attempt to do precisely that, such as Bernanke (2018), and Goldstein and Razin (2015). Given the importance of this question however, more such studies are needed, and we believe future research should therefore address these issues, perhaps using this study as a stepping stone. 


\section{References}

Aigner, E., Aistleitner, M., Glötzl, F., and Kapeller, J. (2018). "The Focus of Academic Economics: Before and After the Crisis," Working paper No. 75, IFNET.

Aizenman, J. (2012). "The Euro and the Global Crises: Finding the Balance between Short Term Stabilization and Forward-Looking Reforms," Working Paper No. 15636, National Bureau of Economic Research.

Athey, Susan and Guido W. Imbens (2019), "Machine Learning Methods that Economists Should Know About," Annual Review of Economics 11, 685-725.

Andrews, D.W.K. (1993), "Tests for Parameter Instability and Structural Change with Unknown Change Point," Econometrica 59, 817-858.

Angrist, J., P. Azoulay, G. Ellison, R. Hill, and S. Lu (2017), "Economic Research Evolves: Fields and Styles," American Economic Review: Papers and Proceedings 107(5), 293-297.

Angrist, J., P. Azoulay, G. Ellison, R. Hill, and S. Lu (2019), "Inside Job or Deep Impact? Extramural Citations and the Influence of Economic Scholarship," Journal of Economic Literature (forthcoming).

Benmelech, Efraim, Jennifer Dlugosz, and Victoria Ivashina (2012), "Securitization without Adverse Selection: The Case of CLOs," Journal of Financial Economics 106(1), 91-113.

Bernanke, Ben S. (2018), "The Real Effects of disrupted Credit: Evidence from the Global Financial Crisis," Brookings Papers on Economic Activity (Fall).

Blei, David M., Andrew Y. Ng, and Michael I. Jordan (2003), "Latent Dirichlet Allocation," Journal of Machine Learning Research 3, 993-1022.

Blei, David M. and Lafferty, John D. (2009), "Topic Models," in Ashok Srivastava and Mehran Sahami (Eds), Text Mining: Classification, Clustering, and Applications (Chapman and Hall/CRC: Boca Raton, FL), pp. 71-94.

Blinder, A., M. Ehrmann, M. Fratzscher, J. de Haan, and D. J. Jansen (2008), "Central Bank Communication and Monetary Policy: A Survey of Theory and Evidence," Journal of Economic Literature 46(4), 910-945.

Bordo, M. D., Jonung, L., and Markiewicz, A. (2013), "A Fiscal Union for the Euro: Some Lessons from History," CESifo Economic Studies 59(3), 449-488.

Born, B., M. Ehrmann, and M. Fratzscher (2010), "Macroprudential Policy and Central Bank Communication," CEPR Discussion Paper No. 8094.

Boukus, E, and J. V. Rosenberg (2006), "The Information Content of FOMC Minutes," Available at SSRN: https://papers.ssrn.com/sol3/papers.cfm?abstract_id=922312.

Bowles, Samuel, and Wendy Carlin (2019), "What Students Learn in Economics 101: Time for a Change," Journal of Economic Literature (forthcoming).

Caballero, Ricardo J. (2010), "The 'Other' Imbalance and the Financial Crisis," Working Paper No. 15636, National Bureau of Economic Research.

Calvo, Guillermo (1998), "Capital Flows and Capital-Market Crises: The Simple Economics of Sudden Stops," Journal of Applied Economics 1, 35-54.

Calvo, G. A., and Mendoza, E. G. (2000) "Rational contagion and the globalization of securities markets," Journal of International Economics 51(1), 79-113.

Cecchetti, Stephen G. (2003), "What the FOMC Says and Does When the Stock Market Booms," manuscript, presented at the 2003 Reserve Bank of Australia annual conference, https://www.rba.gov.au/publications/confs/2003/cecchetti.html.

Chari, V. V., Kehoe, P. J., and E.R. McGrattan, (2005), "Sudden Stops and Output Drops," American Economic Review 95(2), 381-387. 
Conesa, J. C., and T.J. Kehoe (2014), "Is It Too Late to Bail Out the Troubled Countries in the Eurozone?" American Economic Review 104(5), 88-93.

Cukierman, Alex (2009), "The Limits of Transparency," Economic Notes 38(1-2), 1-37.

Claessens, Stijn, and M. Ayhan Kose (2013), "Financial Crises: Explanations, Types, and Implications," manuscript.

Durdu, C. B., and Mendoza, E. G. (2006), “Are Asset Price Guarantees Useful for Preventing Sudden Stops? A Quantitative Investigation of the Globalization Hazard-Moral Hazard Tradeoff," Journal of International Economics 69(1), 84-119.

Ehrmann, M., and M. Fratzscher (2005), “How Should Central Banks Communicate?” Working Paper No. 557, European Central Bank.

Ehrmann, M., and M. Fratzscher (2007), "Communication by Central Bank Committee Members: Different Strategies, Same Effectiveness?” Journal of Money, Credit, and Banking 39(2-3), 509-541.

Ehrmann, M., and M. Fratzscher (2009), "Purdah-On the Rationale for Central Bank Silence around Policy Meetings," Journal of Money, Credit, and Banking 41(2-3), 517-528.

Ehrmann, M, G. Gaballo, P. Hoffmann, and G. Strasser (2019), "Can More Public Information Raise Uncertainty? The International Evidence on Forward Guidance," ECB Working Paper No. 2263.

Fabricant, Solomon (1984), "Toward a Firmer Basis of Economic Policy: The Founding of the NBER," available at: https://data.nber.org/nberhistory/sfabricantrev.pdf.

Fligstein, Neil, Jonah Stuart Brundage, and Michael Schultz (2017), "Seeing Like the Fed: Culture, Cognition, and Framing in the Failure to Anticipate the Financial Crisis of 2008," American Sociological Review 82(5), 879-909.

Gentzkow, M., Kelly, B., and Taddy, M. (2019), “Text as Data,” Journal of Economic Literature 57(3), 535-74.

Georgalakis, James (2017), "Academic in Ivory Towers? It's Time to Change the Record," Times Higher Education (May issue), can be accessed also at the author's blog site at https://blog.esrc.ac.uk/2017/09/14/academics-in-ivory-towers-its-time-to-change-the-record/.

Goldstein, Itay, and Assaf Razin (2015), "Three Branches of Theories of Financial Crises," Foundations and Trends in Finance 10(2), 113-180.

Goldstein, I., Jiang, W., \& Karolyi, G. A. (2019), "To FinTech and Beyond," Review of Financial Studies 32(5), 1647-1661.

Gorton, Gary, and Andrew Metrick (2012a), "Getting Up to Speed on Financial Crisis: a OneWeekend-Reader's Guide,” Journal of Economic Literature 50(1), 128-150.

Gorton, Gary, and Andrew Metrick (2012b), "Securitized Banking and the Run on Repo," Journal of Financial Economics 104, 425-451.

Hakkio, C., and Keeton, W. (2009), "Financial Stress: What Is It, How Can It Be Measured, and Why Does It Matter?" Federal Reserve Bank of Kansas City Economic Review 94(2), 5-50.

Hansen, B.E. (1997), “Approximate Asymptotic p-Values for Structural Change Tests,” Journal of Business and Economic Statistics 15, 60-67.

Hansen, Stephen and Michael McMahon (2016), "Shocking Language: Understanding the Macroeconomic Effects of Central Bank Communication," Journal of International Economics 99(1), S114-S133.

Hansen, S., McMahon, M, and Prat, A. (2017), "Transparency and Deliberation within the FOMC: a Computational Linguistics Approach," Quarterly Journal of Economics 133(2), 801-870. 
Holló, D., Kremer, M., and Lo Duca, M. (2012), “CISS-a Composite Indicator of Systemic Stress in the Financial System," Working Paper No. 1426, European Central Bank.

Jansen, David-Jan, and Jakob de Haan (2011), "An Assessment of the Consistency of ECB Communication Using Wordscores," De Nederlandsche Bank Working Paper No. 259.

Jegadeesh, Narasimhan and Wu, Di Andrew (2016), "Deciphering Fedspeak: The Information Content of FOMC Meetings," manuscript, presented at the January 2016 AEA annual conference in San Francisco, http://www.aeaweb.org/conference/2016/retrieve.php?pdfid=1136.

Kansoy, Fatih (2019), "FOMC Minutes: As a Source of Monetary Policy Surprise," manuscript, University of Nottingham.

Keida, M. and Y. Takeda (2018), "The Arts of Central Bank Communication: A Topic Analysis on Words of the Bank of Japan's Governors," presented at the 2019 AEA Annual Conference.

Knispelis, Andrius (2016), "LDA Topic Models: Turning Words into Meaning," a presentation, available at: https://www.youtube.com/watch?v=3mHy4OSyRf0.

Kosnik, L. R. D. (2015), "What Have Economists Been Doing for the Last 50 Years? A Text Analysis of Published Academic Research from 1960-2010," Economics e-Journal 9, 1-38.

Krishnamurthy, Arvind, Stefan Nagel, and Dmitry Orlov (2014), "Sizing Up Repo," Journal of Finance 69(6), 2381-2417.

Krugman, Paul (2013), "Understanding the NBER," New York Times, April 22, 2013, https://krugman.blogs.nytimes.com/2013/04/22/understanding-the-nber/.

Kryvtsov and Petersen (2019), "Central Bank Communication That Works: Lessons from Lab Experiments," Staff Working Paper, No. 2019-21, Bank of Canada.

Larsen, V. H., and Thorsrud, L. A. (2019), "The Value of News for Economic Developments," Journal of Econometrics 210(1), 203-218.

Lüdering, J., and Tillmann, P. (2018), "Monetary Policy on Twitter and Asset Prices: Evidence from Computational Text Analysis," North American Journal of Economics and Finance (forthcoming).

Mendoza, Enrique G., and Vivian Z. Yue (2012), “A General Equilibrium Model of Sovereign Default and Business Cycles," Quarterly Journal of Economics 127(2), 889-946.

Mendoza, E. G. (2006), "Lessons from the Debt-Deflation Theory of Sudden Stops," American Economic Review 96(2), 411-416.

Mendoza, E. G. (2008), "Sudden Stops, Financial Crises and Leverage: a Fisherian Deflation of Tobin's Q," Working paper No. 14444. National Bureau of Economic Research.

Mendoza, E. G., and Smith, K. A. (2002), "Margin Calls, Trading Costs, and Asset Prices in Emerging Markets: The Financial Mechanics of the 'Sudden Stop' Phenomenon," Working paper No. 9286. National Bureau of Economic Research.

Paul, M., and Girju, R. (2009), "Cross-Cultural Analysis of Blogs and Forums with MixedCollection Topic Models," Proceedings of the 2009 Conference on Empirical Methods in Natural Language Processing 3 (1408-1417), Association for Computational Linguistics. Poole, William (2005), "How Predictable Is Fed Policy? Federal Reserve Bank of St. Louis Review 87(6), 659-668.

Quandt, R.E. (1960), "Tests of Hypotheses that a Linear System Obeys Two Separate Regimes," Journal of the American Statistical Association 55, 324-330.

Razin, A. (2014), Understanding Global Crises: An Emerging Paradigm (Cambridge, MA: MIT Press).

Razin, A., and Rosefielde, S. (2012), "What Really Ails the Eurozone? Faulty Supranational 
Architecture," Contemporary Economics 6(4), 10-18.

Reis, R. (2018), "Is Something Really Wrong with Macroeconomics?" Oxford Review of Economic Policy 34(1-2), 132-155.

Romer, David (2010), "A New Data Set on Monetary Policy: The Economic Forecasts of Individual Members of the FOMC," Journal of Money, Credit, and Banking 42(5), 951-957. Shiller, R (2017), "Narrative Economics," American Economic Review 107(4), 967-1004. Shirota, Y., Sakura, T., and Chakraborty, B. (2016), "Monetary Policy Topic Extraction by Using LDA: Termination of Asian Financial Crisis," Information Modelling and Knowledge Bases 27, Frontiers in Artificial Intelligence and Applications, Vol. 280, 188-198.

Stemler, S. (2001), "An Overview of Content Analysis, Practical Assessment," Research and Evaluation 7, 137-146.

Steyvers, M., and T. Griffiths (2007), "Probabilistic Topic Models," in T. Landauer, et al., ed., Handbook of Latent Semantic Analysis (Mahwah, NJ: Lawrence Erlbaum Associates).

Thornton, Daniel L. (2006), "When Did the FOMC Begin Targeting the Federal Funds Rate? What the Verbatim Transcripts Tell Us," Journal of Money, Credit and Banking 38(8), 2039-2071.

Vegh, C. A., Vuletin, G. (2014), "Social Implications of Fiscal Policy Responses during Crises," Working paper No 19828, National Bureau of Economic Research.

Weber, R. P. (1990), Basic Content Analysis, $2^{\text {nd }}$ Ed. (Newbury Park, CA: Sage Publishing).

Wehrheim, L. (2019), "Economic History Goes Digital: Topic Modeling the Journal of Economic History," Cliometrica 13(1), 83-125.

Woodford, Michael (2005), "Central-Bank Communication and Policy Effectiveness," In The Greenspan Era: Lessons for the Future (Kansas City: Federal Reserve Bank of Kansas City), 399-474. 
Figure 1. Total number of NBER WPs published

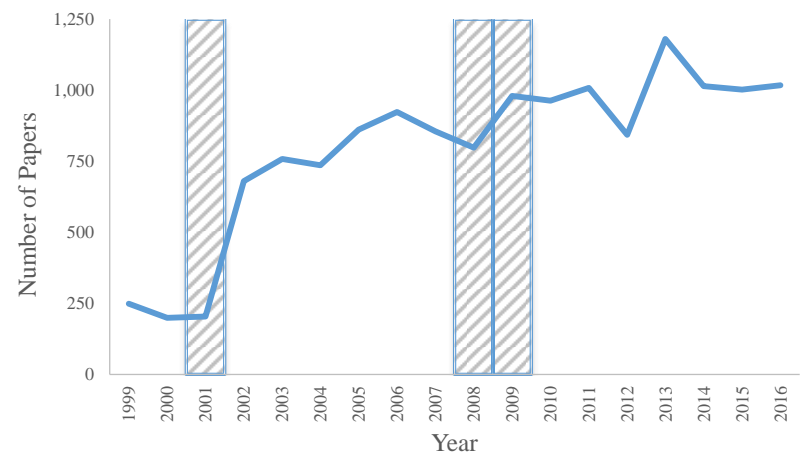

$\underline{\text { Note: }}$ Shaded areas indicate NBER recession periods.

Figure 2a. Frequency of the word 'crisis/crises'

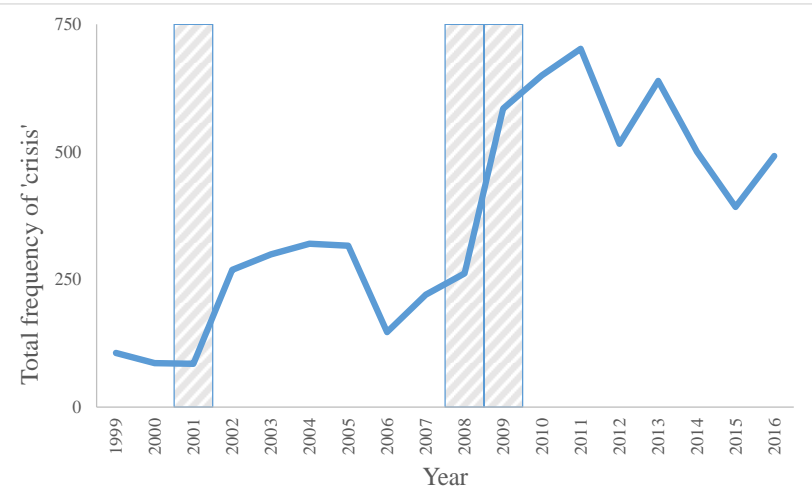

Note: The figure presents the total number of appearances of the word crisis in the first five paragraphs of the introductory section of all NBER WPs. Shaded areas indicate NBER recession periods.

Figure $2 b$. Average frequency of the word 'crisis/crises' per WP

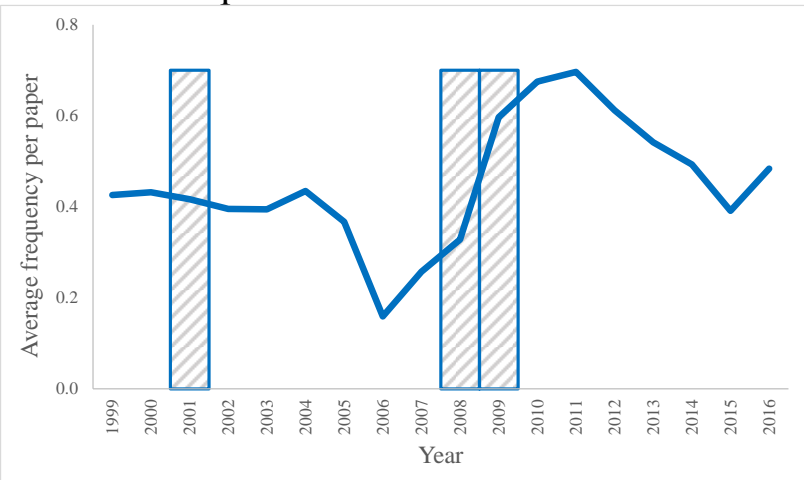

Note: The figure presents the average number of appearances of the word crisis in the first five paragraphs of the introductory section, per WP. Shaded areas indicate NBER recession periods. 
Figure 2c. The \% of crisis WPs and Wald test statistic for structural breaks

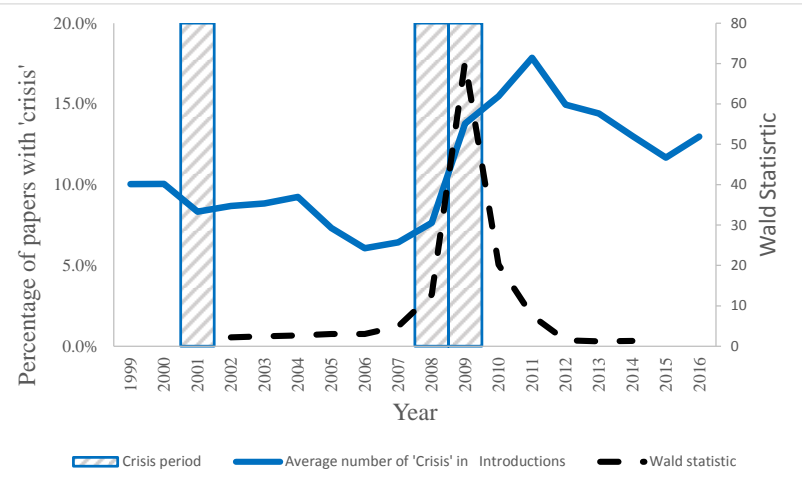

Figure 3a. The \% of crisis WPs and 2-year lagged Composite Indicator of Systemic Stress

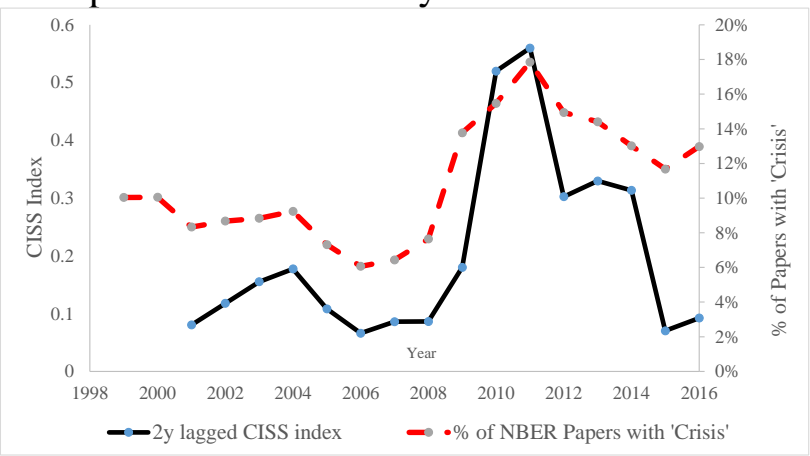

Figure $3 \mathrm{~b}$. The $\%$ of crisis WPs and 2-year lagged Kansas City Financial Stress Index

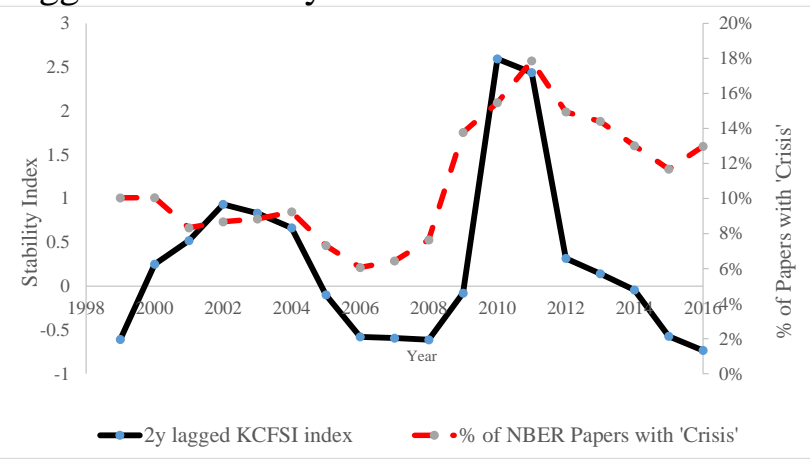


Figure 3c. Frequency of crisis WPs and 2-year lagged CISS index

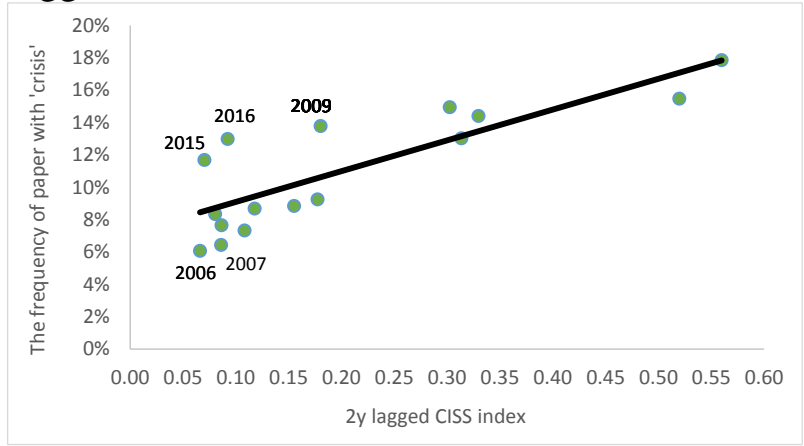

Figure 4. Average annual \% of crisis WPs by NBER research programs
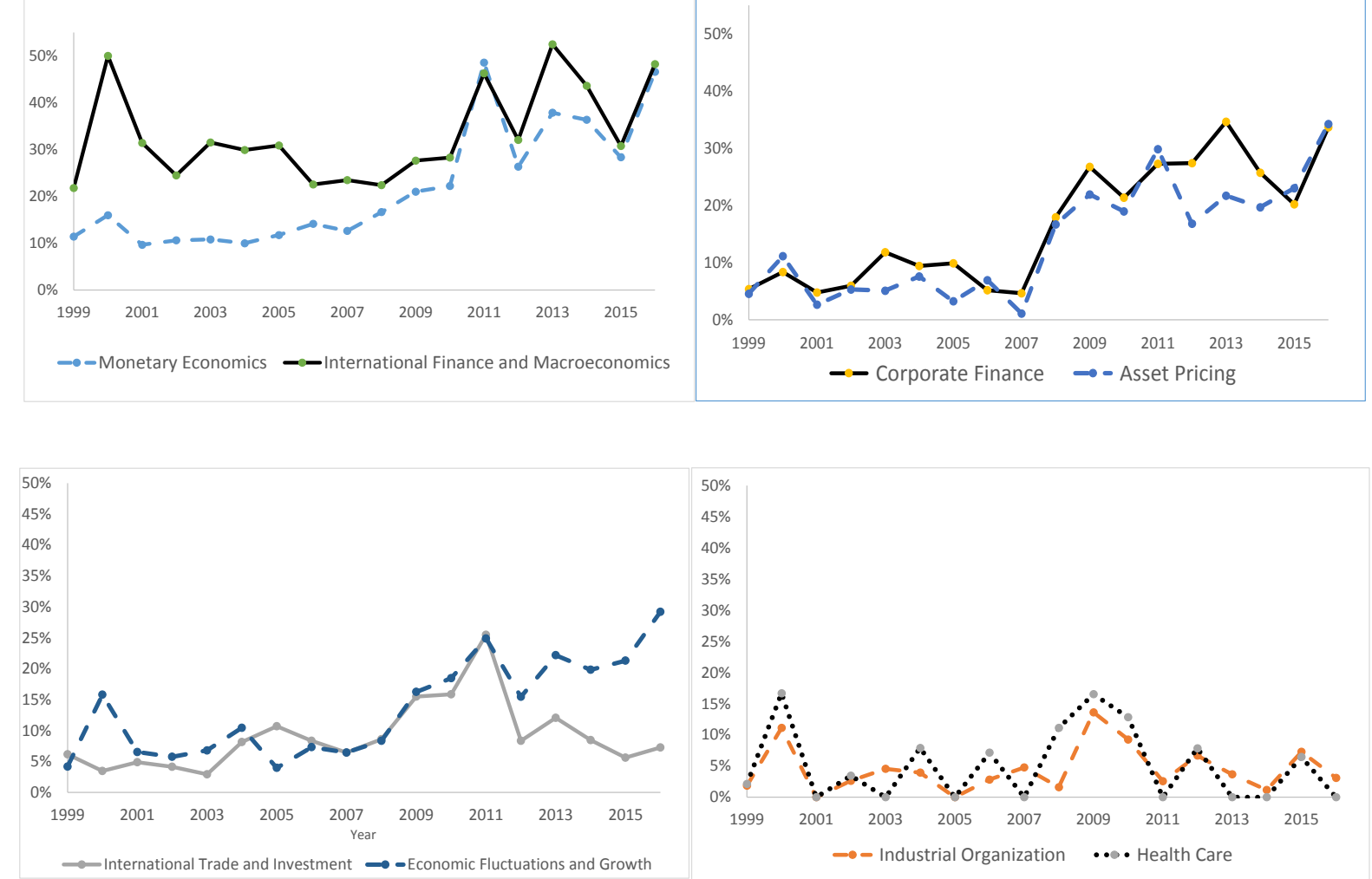
Figure 5. Average weight of all crisis topics and the Wald statistic time series (1999-2016)

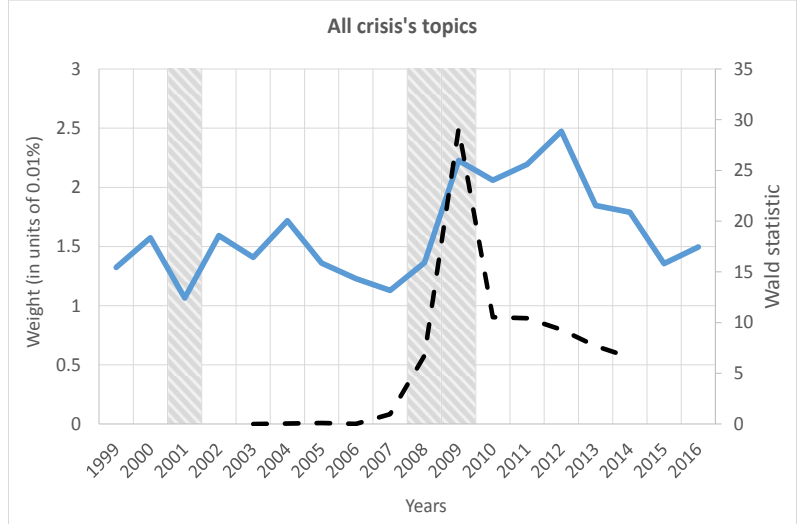

Note: The figure shows the sum of the weights of all 9 topics with the word 'crisis' out of the 500 topics that were identified by the LDA algorithm for the abstracts of the entire database of NBER WPs published between 1999 and 2016 (solid line). We also present the annual Wald test statistic for the sum of all crisis' topics for the period between 2003 and 2014 (dashed line).

Figure 6. The average annual weight of the 9 crisis topics, 1999-2016
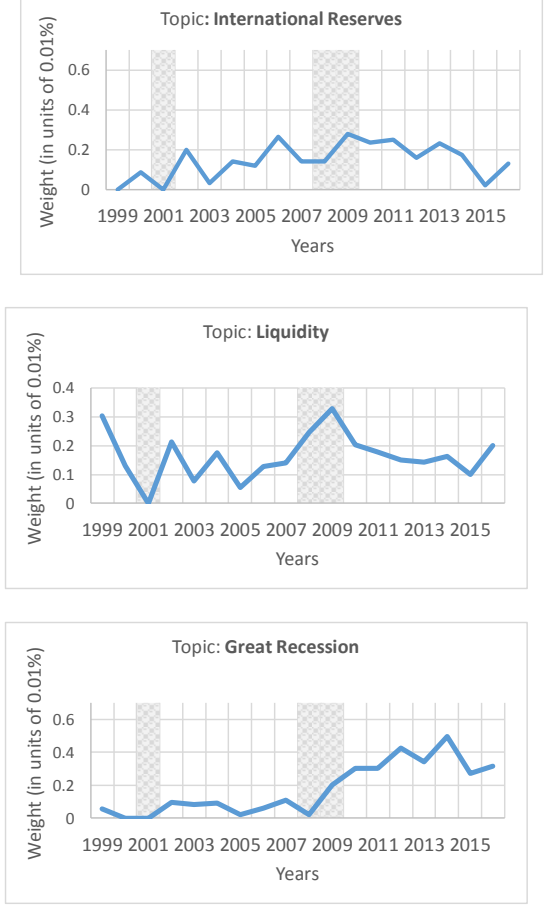
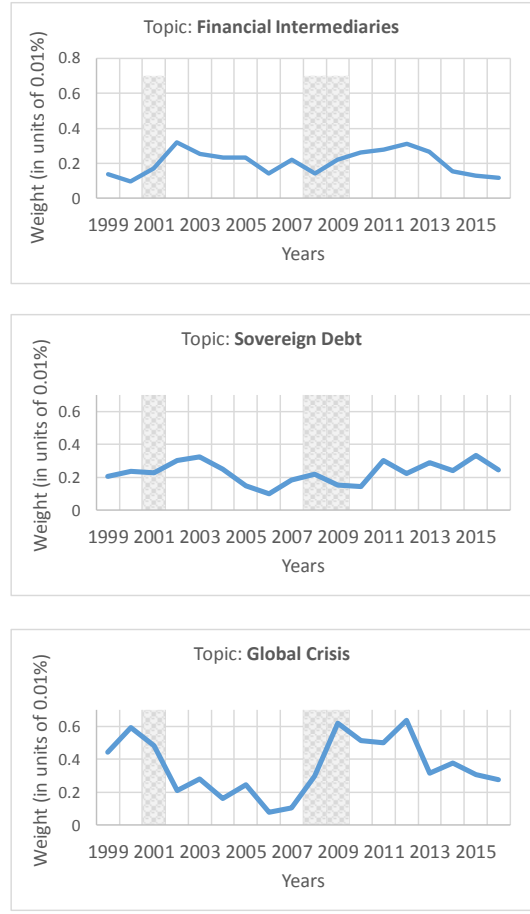
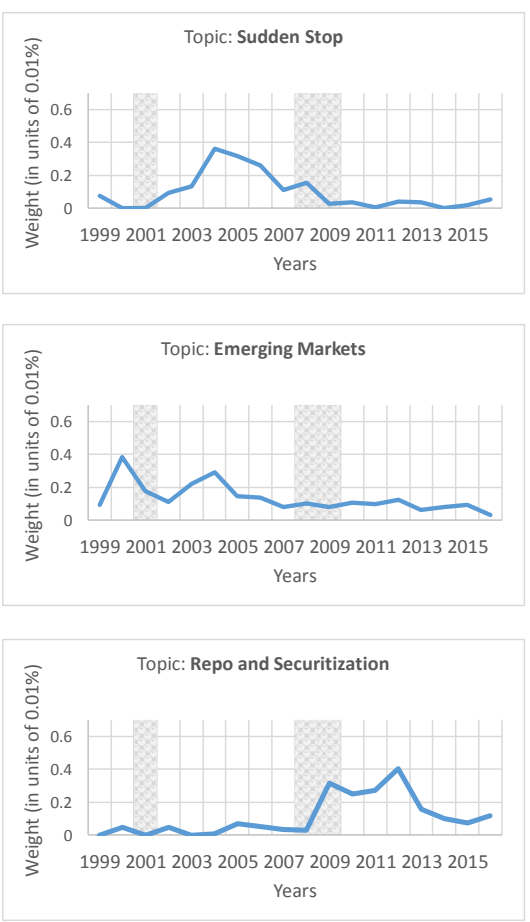
Figure 7. The Wald test statistic time series for 9 crisis topics, 2003-2014
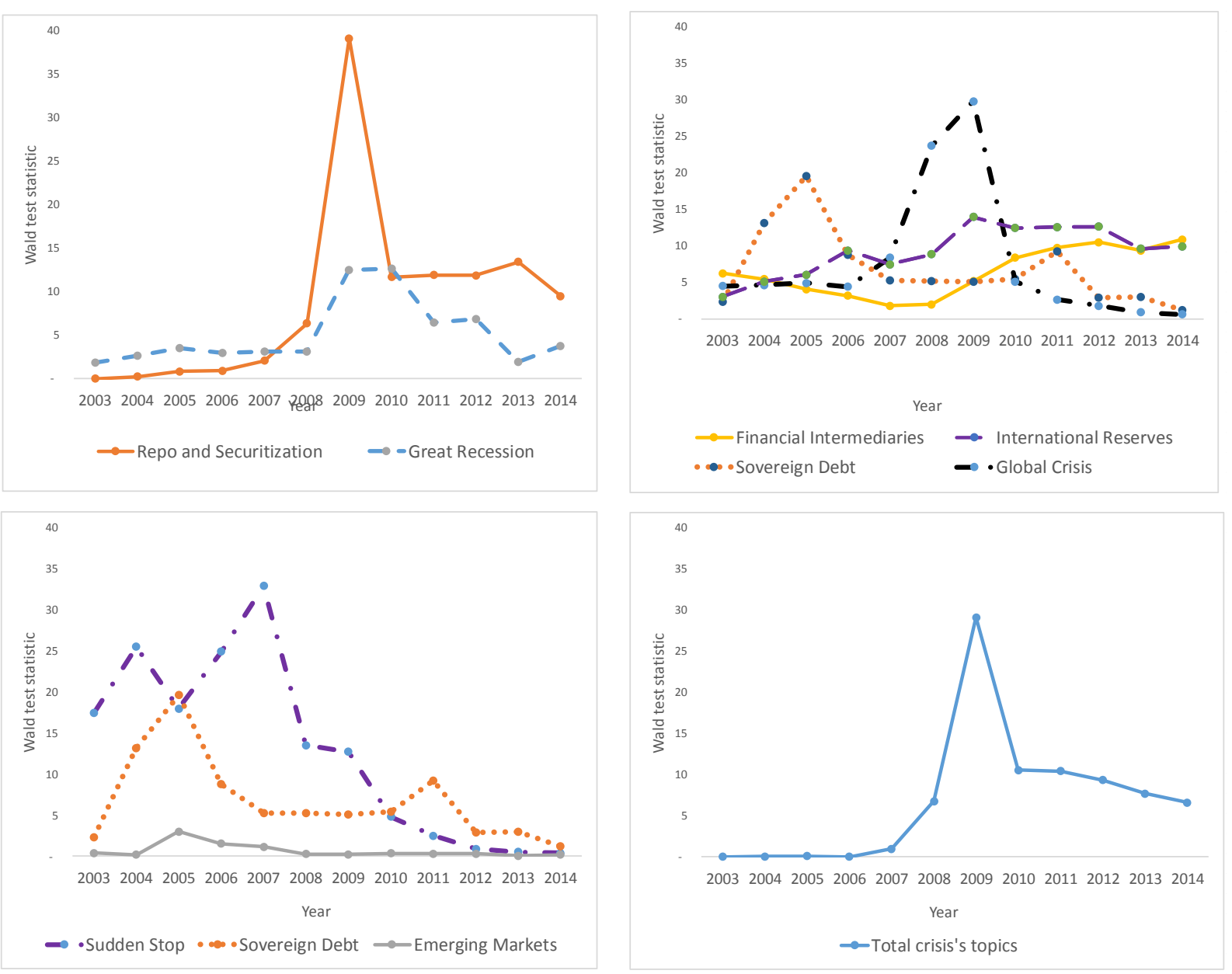

Note: The figure presents the annual Wald statistic for different crisis' topics for the period between 2003 and 2014 . First, the abstracts of the NBER WPs that were published between 1999 and 2016 were analyzed using LDA, yielding 500 topics. Each topic contains 20 words. Next, we calculate the average weight of a topic in a WP for each year, and finally we calculate the Wald test statistic for known structural breaks for each year. 
Table 1. NBER WPs, descriptive statistics, 1999-2016

\begin{tabular}{|lcccccc|}
\hline $\begin{array}{l}\text { Panel A: Descriptive } \\
\text { statistics for all WPs }\end{array}$ & $\begin{array}{c}\text { Monetary } \\
\text { Economics }\end{array}$ & $\begin{array}{c}\text { Int. } \\
\text { Trade }\end{array}$ & $\begin{array}{c}\text { Corporate } \\
\text { Finance }\end{array}$ & $\begin{array}{c}\text { Asset } \\
\text { Pricing }\end{array}$ & $\begin{array}{c}\text { Int. } \\
\text { Finance } \\
\text { and Macro }\end{array}$ & $\begin{array}{c}\text { Economic } \\
\text { Fluctuations } \\
\text { and Growth }\end{array}$ \\
$\begin{array}{c}\text { All WPs } \\
\text { Wverage number of WPs }\end{array}$ & 109.90 & 106.61 & 104.06 & 117.83 & 127.72 & 191.28 \\
\hline $\begin{array}{l}\text { Average number of WPs } \\
\text { before 2008 }\end{array}$ & 80.10 & 96.89 & 77.78 & 96.67 & 109.00 & 145.11 \\
\hline $\begin{array}{l}\text { Average number of WPs } \\
\text { after 2008 }\end{array}$ & 139.80 & 116.33 & 130.33 & 139.00 & 146.44 & 237.44 \\
\hline$t$-test for mean-difference & 20.70 & 6.10 & 17.52 & 13.27 & 11.90 & 25.54 \\
\hline
\end{tabular}

Table 2. NBER crisis WPs, descriptive statistics, 1999-2016

\begin{tabular}{|c|c|c|c|c|c|c|c|}
\hline & $\begin{array}{l}\text { Monetary } \\
\text { Economics }\end{array}$ & $\begin{array}{l}\text { Int. } \\
\text { Trade }\end{array}$ & $\begin{array}{l}\text { Corporate } \\
\text { Finance }\end{array}$ & $\begin{array}{l}\text { Asset } \\
\text { Pricing }\end{array}$ & $\begin{array}{c}\text { Int. } \\
\text { Finance } \\
\text { and Macro }\end{array}$ & $\begin{array}{l}\text { Economic } \\
\text { Fluctuations } \\
\text { and Growth }\end{array}$ & $\begin{array}{c}\text { All } \\
\text { WPs }\end{array}$ \\
\hline Average $\%$ of crisis WPs & $21.7 \%$ & $9.0 \%$ & $16.7 \%$ & $13.9 \%$ & $33.2 \%$ & $13.5 \%$ & $11.4 \%$ \\
\hline Min. \% during 1999-2016 & $9.7 \%$ & $2.9 \%$ & $4.7 \%$ & $1.1 \%$ & $21.8 \%$ & $4.0 \%$ & $6.1 \%$ \\
\hline Max. \% during 1999-2016 & $48.6 \%$ & $25.5 \%$ & $34.6 \%$ & $34.2 \%$ & $52.5 \%$ & $29.2 \%$ & $17.9 \%$ \\
\hline Average $\%$ before 2008 & $11.9 \%$ & $6.1 \%$ & $7.3 \%$ & $5.3 \%$ & $29.6 \%$ & $7.5 \%$ & $8.3 \%$ \\
\hline Average $\%$ after 2008 & $31.6 \%$ & $11.9 \%$ & $26.1 \%$ & $22.5 \%$ & $36.9 \%$ & $19.5 \%$ & $13.5 \%$ \\
\hline (\% after $) /(\%$ before $)$ & 2.65 & 1.95 & 3.57 & 4.24 & 1.24 & 2.6 & 1.62 \\
\hline$z$-test for mean-difference & $11.04 * * *$ & $4.49 * * *$ & $11.68 * * *$ & $12.30 * * *$ & $3.70 * * *$ & $10.74 * * *$ & $9.95 * * *$ \\
\hline$\%$ out of all crisis WPs & $26.4 \%$ & $10.6 \%$ & $19.1 \%$ & $18.1 \%$ & $46.8 \%$ & $28.5 \%$ & $100.0 \%$ \\
\hline Number of crisis WPs & 468 & 189 & 361 & 323 & 737 & 510 & 1,632 \\
\hline
\end{tabular}

*** Significant at $p<0.01$

Table 3. Wald test statistic for structural breaks for the annual frequency of WPs with word crisis for selected NBER programs

\begin{tabular}{|c|c|c|c|c|c|c|c|}
\hline & $\begin{array}{l}\text { Monetary } \\
\text { Economics }\end{array}$ & $\begin{array}{l}\text { Int. } \\
\text { Trade }\end{array}$ & $\begin{array}{l}\text { Corporate } \\
\text { Finance }\end{array}$ & $\begin{array}{c}\text { Asset } \\
\text { Pricing }\end{array}$ & $\begin{array}{c}\text { Int. } \\
\text { Finance } \\
\text { and } \\
\text { Macro }\end{array}$ & $\begin{array}{l}\text { Economic } \\
\text { Fluctuations } \\
\text { and Growth }\end{array}$ & $\begin{array}{c}\text { All } \\
\text { WPs }\end{array}$ \\
\hline Estimated break point & 2011 & 2012 & 2008 & 2008 & 2011 & 2009 & 2009 \\
\hline Sup-Wald $(Q L R)$ test statistic & 10.8 & 18.78 & 14.01 & 14.86 & 7.88 & 13.04 & 70.36 \\
\hline$p$-value & $6.00 \%$ & $0.21 \%$ & $1.75 \%$ & $1.21 \%$ & $22.00 \%$ & $2.67 \%$ & $0.00 \%$ \\
\hline \multicolumn{8}{|l|}{ Known break point at 2008} \\
\hline Sup-Wald (QLR) test statistic & 5.77 & 7.47 & 14.01 & 14.86 & 5.31 & 9.31 & 20.19 \\
\hline$p>\chi^{2}$ & $5.58 \%$ & $2.38 \%$ & $0.09 \%$ & $0.06 \%$ & $7.00 \%$ & $0.95 \%$ & $0.00 \%$ \\
\hline
\end{tabular}


Table 4. Regressions of the annual \% of crisis WPs on indexes of financial stability

\begin{tabular}{|c|c|c|c|c|}
\hline & (1) & (2) & (3) & (4) \\
\hline Intercept & $\begin{array}{l}0.072 \text { *** } \\
(8.08)\end{array}$ & $\begin{array}{l}0.10^{* * * *} \\
(12.31)\end{array}$ & $\begin{array}{l}0.09 \text { *** } \\
(13.9)\end{array}$ & $\begin{array}{l}0.076^{* * * *} \\
(26.34)\end{array}$ \\
\hline 2-year lagged CISS index & $\begin{array}{l}0.19 * * * \\
(5.44)\end{array}$ & & & $\begin{array}{l}0.013^{* * *} \\
(6.2)\end{array}$ \\
\hline 2-year lagged KCFSI index & & $\begin{array}{l}0.019 * * \\
(2.47)\end{array}$ & & \\
\hline Dummy for post-2008 & & & $\begin{array}{l}0.06 * * * \\
(5.5)\end{array}$ & $\begin{array}{l}0.06^{* * * *} \\
(14.3)\end{array}$ \\
\hline$p>F, p>\chi^{2}$ & $0.01 \%$ & $2.53 \%$ & $0.01 \%$ & $0.00 \%$ \\
\hline$R^{2}$ & 0.68 & 0.28 & 0.66 & 0.96 \\
\hline
\end{tabular}

$t$-test statistics are shown in parentheses.

Table 5. Regressions of the annual \% of crisis WPs on the annual \% of all NBER crisis WPs, by research program

\begin{tabular}{|lcccccc|}
\hline & $\begin{array}{c}\text { Monetary } \\
\text { Economics }\end{array}$ & Int. Trade & $\begin{array}{c}\text { Corporate } \\
\text { Finance }\end{array}$ & Asset Pricing & $\begin{array}{c}\text { Int. Finance } \\
\text { and Macro }\end{array}$ & $\begin{array}{c}\text { Economic } \\
\text { Fluctuations } \\
\text { and Growth }\end{array}$ \\
\hline Intercept & -10.20 & -2.75 & $-10.91^{* *}$ & $-11.22^{* *}$ & $15.20^{* *}$ & $-6.64^{*}$ \\
\hline & $(-1.54)$ & $(-0.82)$ & $(-2.18)$ & $(-2.24)$ & $(2.16)$ & $(-1.73)$ \\
Slope & $2.92^{* * *}$ & $1.08^{* * *}$ & $2.52^{* * *}$ & $2.30^{* * *}$ & $1.65^{* * *}$ & $1.84^{* * *}$ \\
\hline
\end{tabular}

Note: The figures in the parentheses are the $t$-test statistics. *** $p<0.01, * * p<0.05, * p<0.10$.

Table 6. Number of crisis topics the LDA algorithm identifies for different values of $\alpha$ and $K$

\begin{tabular}{|l|c|c|c|c|c|c|c|}
\hline \multicolumn{2}{|c|}{} & \multicolumn{7}{|c|}{ Document-topic density $(\alpha)$} \\
\cline { 3 - 9 } & 250 & $0.5 \%$ & $\mathbf{1 \%}$ & $5 \%$ & $10 \%$ & $20 \%$ & $50 \%$ \\
\hline \multirow{3}{*}{ Number of topics $(K)$} & $\mathbf{5 0 0}$ & 11 & 7 & 4 & 2 & 1 & 1 \\
\cline { 2 - 9 } & 750 & 15 & 13 & 8 & 5 & 3 & 1 \\
\cline { 2 - 9 } & 1,000 & 13 & 13 & 7 & 7 & 4 & 3 \\
\hline
\end{tabular}


Table 7. The 9 crisis topics identified by the LDA algorithm, and the top- 10 words in each topic

\begin{tabular}{|l|llllllllll|}
\hline Crisis Topic & \multicolumn{8}{|c|}{ Top-10 Words in Each Topic } \\
\hline International & reserv & crisi & intern & countri & financi & emerg & extern & debt & accumul & manag \\
Reserves & 253 & 129 & 110 & 105 & 87 & 76 & 74 & 62 & 58 & 51 \\
\hline Financial & financi & market & develop & sector & intermediari & economi & bank & financ & institut & crisi \\
Intermediaries & 1,069 & 214 & 177 & 173 & 106 & 106 & 84 & 76 & 71 & $60(14)$ \\
\hline Sudden & stop & sudden & revers & capit & account & current & inflow & foreign & crisi & probabl \\
Stop & 209 & 188 & 95 & 74 & 55 & 41 & 35 & 30 & 28 & 24 \\
\hline Liquidity & liquid & asset & market & illiquid & price & increas & provid & lead & trade & crisi \\
& 619 & 247 & 126 & 97 & 61 & 52 & 49 & 46 & 41 & $33(13)$ \\
\hline Sovereign & debt & default & govern & sovereign & countri & borrow & domest & creditor & crisi & repay \\
Debt & 847 & 192 & 117 & 111 & 83 & 81 & 57 & 50 & 50 & 43 \\
\hline Emerging & market & countri & emerg & economi & develop & advanc & capit & imf & strong & crisi \\
Markets & 323 & 321 & 300 & 192 & 165 & 93 & 40 & 35 & 34 & $26(13)$ \\
\hline Great & recess & great & depress & recoveri & declin & downturn & larg & period & econom & crisi \\
Recession & 381 & 311 & 130 & 118 & 109 & 73 & 72 & 71 & 64 & $39(17)$ \\
\hline Global & crisi & financi & bank & global & market & system & countri & emerg & paper & recent \\
Crisis & 1,176 & 612 & 155 & 107 & 86 & 84 & 68 & 64 & 62 & 55 \\
\hline Repo and & loan & secur & securit & collater & market & crisi & financi & credit & repo & facil \\
Securitization & 97 & 80 & 68 & 66 & 63 & 60 & 51 & 49 & 46 & 46 \\
\hline
\end{tabular}

Note: The figure presents the top 10 words of crisis' topics for a corpus that includes all abstracts of the NBER WPs published in 1999-2016. First, the abstracts of the WPs that were published between 1999 and 2016 were analyzed using LDA, yielding 500 topics. Each topic contains 20 words. Out of the 500 topics, 9 contain the word 'crisis' and we present the words of these topics. The table shows the most frequent words of each topics as well as the frequency of the words in a topic. In case that the word 'crisis' is not a part of the 10 most frequent words, we replace it with the $10^{\text {th }}$ word and show in brackets the rank of the word crisis within the topics.

Table 8. Annual rank of the average weight of the crisis topics, 1999-2016

\begin{tabular}{|c|c|c|r|r|r|r|r|r|r|}
\hline Year & $\begin{array}{c}\text { International } \\
\text { Reserves }\end{array}$ & $\begin{array}{c}\text { Financial } \\
\text { Intermediaries }\end{array}$ & $\begin{array}{c}\text { Sudden } \\
\text { Stop }\end{array}$ & Liquidity & $\begin{array}{c}\text { Sovereign } \\
\text { Debt }\end{array}$ & $\begin{array}{c}\text { Emerging } \\
\text { Markets }\end{array}$ & $\begin{array}{c}\text { Great } \\
\text { Recession }\end{array}$ & $\begin{array}{c}\text { Global } \\
\text { Crisis }\end{array}$ & $\begin{array}{c}\text { Repo and } \\
\text { Securitization }\end{array}$ \\
\hline 1999 & 392 & 208 & 349 & 61 & 151 & 203 & 317 & 12 & 482 \\
\hline 2000 & 256 & 221 & 450 & 244 & 127 & 33 & 219 & 9 & 366 \\
\hline 2001 & 397 & 105 & 409 & 358 & 119 & 149 & 363 & 27 & 446 \\
\hline 2002 & 123 & 30 & 247 & 135 & 43 & 179 & 207 & 58 & 415 \\
\hline 2003 & 385 & 81 & 251 & 287 & 39 & 62 & 290 & 57 & 494 \\
\hline 2004 & 192 & 54 & 32 & 114 & 53 & 42 & 233 & 118 & 493 \\
\hline 2005 & 264 & 92 & 50 & 298 & 137 & 203 & 387 & 72 & 325 \\
\hline 2006 & 77 & 94 & 88 & 224 & 240 & 165 & 317 & 302 & 390 \\
\hline 2007 & 181 & 86 & 260 & 202 & 119 & 242 & 241 & 218 & 442 \\
\hline 2008 & 198 & 139 & 181 & 72 & 99 & 187 & 414 & 25 & 423 \\
\hline 2009 & 53 & 66 & 477 & 32 & 193 & 269 & 71 & 1 & 40 \\
\hline 2010 & 77 & 47 & 465 & 67 & 210 & 219 & 19 & 5 & 65 \\
\hline 2011 & 74 & 36 & 468 & 135 & 50 & 180 & 25 & 1 & 70 \\
\hline 2012 & 169 & 38 & 375 & 145 & 89 & 176 & 6 & 1 & 29 \\
\hline 2013 & 103 & 35 & 400 & 164 & 61 & 238 & 18 & 34 & 193 \\
\hline 2014 & 123 & 116 & 456 & 120 & 88 & 328 & 6 & 19 & 335 \\
\hline 2015 & 427 & 179 & 442 & 266 & 25 & 198 & 29 & 33 & 371 \\
\hline 2016 & 175 & 135 & 426 & 114 & 74 & 343 & 23 & 55 & 223 \\
\hline
\end{tabular}


Table 9. The average weights of NBER WPs for the pre-crisis period (2005-2008), for the immediate post-crisis period (2009-2012), and for the post-crisis period (2013-206)

Panel A. The pre-crisis period (2005-2008) and the immediate post-crisis period (2009-2012)

\begin{tabular}{|lcccccccccc|}
\hline & $\begin{array}{c}\text { Int. } \\
\text { Reserves }\end{array}$ & $\begin{array}{c}\text { Fin. } \\
\text { Interm. }\end{array}$ & $\begin{array}{c}\text { Sudden } \\
\text { Stop }\end{array}$ & Liquidity & $\begin{array}{c}\text { Sovereign } \\
\text { Debt }\end{array}$ & $\begin{array}{c}\text { Emerging } \\
\text { Market }\end{array}$ & $\begin{array}{c}\text { Great } \\
\text { Recession }\end{array}$ & $\begin{array}{c}\text { Global } \\
\text { Crisis }\end{array}$ & $\begin{array}{l}\text { Repo \& } \\
\text { Securit. }\end{array}$ & All Topics \\
\hline Av 2005-2008 & 0.17 & 0.18 & 0.21 & 0.14 & 0.16 & 0.12 & 0.05 & 0.18 & 0.05 & 1.27 \\
\hline Av 2009-2012 & 0.23 & 0.27 & 0.03 & 0.22 & 0.21 & 0.10 & 0.30 & 0.56 & 0.31 & 2.23 \\
\hline Av 2005-2012 & 0.20 & 0.23 & 0.12 & 0.18 & 0.19 & 0.11 & 0.18 & 0.38 & 0.18 & 1.77 \\
\hline z-test for mean-diff & 0.6 & 0.7 & $-\mathbf{2 . 3} * *$ & 0.8 & 0.5 & -0.2 & $\mathbf{2 . 5} * * *$ & $\mathbf{2 . 7} * * *$ & $\mathbf{2 . 6} * * *$ & $\mathbf{3 . 1} * * *$ \\
\hline
\end{tabular}

Panel B. The immediate post-crisis period (2009-2012) and the post-crisis period (2013-2016)

\begin{tabular}{|lcccccccccc|}
\hline & $\begin{array}{c}\text { Int. } \\
\text { Reserves }\end{array}$ & $\begin{array}{c}\text { Fin. } \\
\text { Interm. }\end{array}$ & $\begin{array}{c}\text { Sudden } \\
\text { Stop }\end{array}$ & Liquidity & $\begin{array}{c}\text { Sovereign } \\
\text { Debt }\end{array}$ & $\begin{array}{c}\text { Emerging } \\
\text { Market }\end{array}$ & $\begin{array}{c}\text { Great } \\
\text { Recession }\end{array}$ & $\begin{array}{c}\text { Global } \\
\text { Crisis }\end{array}$ & $\begin{array}{l}\text { Repo \& } \\
\text { Securit. }\end{array}$ & All Topics \\
\hline Av 2009-2012 & 0.23 & 0.27 & 0.03 & 0.22 & 0.21 & 0.10 & 0.30 & 0.56 & 0.31 & 2.23 \\
\hline Av 2013-2016 & 0.14 & 0.17 & 0.03 & 0.15 & 0.28 & 0.07 & 0.36 & 0.32 & 0.12 & 1.63 \\
\hline Av 2009-2016 & 0.19 & 0.22 & 0.03 & 0.18 & 0.24 & 0.08 & 0.33 & 0.44 & 0.21 & 1.92 \\
\hline z-test for mean-diff & -1.0 & -1.0 & 0.0 & -0.7 & 0.7 & -0.6 & 0.4 & $\mathbf{- 1 . 8}^{*}$ & $\mathbf{- 2 . 0} * *$ & $-\mathbf{2 . 1} * *$ \\
\hline
\end{tabular}

Panel C. The pre-crisis period (2005-2008) and the post-crisis period (2013-2016)

\begin{tabular}{|lcccccccccc|}
\hline & $\begin{array}{c}\text { Int. } \\
\text { Reserves }\end{array}$ & $\begin{array}{c}\text { Fin. } \\
\text { Interm. }\end{array}$ & $\begin{array}{c}\text { Sudden } \\
\text { Stop }\end{array}$ & Liquidity & $\begin{array}{c}\text { Sovereign } \\
\text { Debt }\end{array}$ & $\begin{array}{c}\text { Emerging } \\
\text { Market }\end{array}$ & $\begin{array}{c}\text { Great } \\
\text { Recession }\end{array}$ & $\begin{array}{c}\text { Global } \\
\text { Crisis }\end{array}$ & $\begin{array}{l}\text { Repo \& } \\
\text { Securit. }\end{array}$ & All Topics \\
\hline Av 2005-2008 & 0.17 & 0.18 & 0.21 & 0.14 & 0.16 & 0.12 & 0.05 & 0.18 & 0.05 & 1.27 \\
\hline Av 2013-2016 & 0.14 & 0.17 & 0.03 & 0.15 & 0.28 & 0.07 & 0.36 & 0.32 & 0.12 & 1.63 \\
\hline $\begin{array}{l}\text { Av 2005-2008 \& } \\
\text { 2013-2016 }\end{array}$ & 0.16 & 0.18 & 0.11 & 0.15 & 0.23 & 0.09 & 0.22 & 0.26 & 0.08 & 1.47 \\
\hline$z$-test for mean-diff & -0.3 & -0.1 & $-\mathbf{2 . 4 * * *}$ & 0.1 & 1.0 & -0.7 & $\mathbf{2 . 7} * * *$ & 1.2 & 1.0 & 1.3 \\
\hline
\end{tabular}

Note: $* * * p<0.01, * * p<0.05, * p<0.10$. The averages are reported in units of $0.01 \%$. 
Table 10. Wald test statistic for structural breaks for the annual weight of each of the 9 crisis topics

\begin{tabular}{|c|c|c|c|c|c|c|}
\hline \multicolumn{4}{|c|}{ Wald Test Statistic around the Crisis Time } & \multicolumn{3}{|c|}{ sup-Wald Test } \\
\hline & 2007 & 2008 & 2009 & $\begin{array}{c}\text { Estimate } \\
\text { Break } \\
\text { Point }\end{array}$ & $\begin{array}{c}\text { Sup-Wald } \\
(Q L R) \\
\text { Statistic }\end{array}$ & $p$-value \\
\hline International Reserves & $7.5^{* *}$ & $8.9 * *$ & $14.0 * * *$ & 2009 & 14.0 & $1.78 \%$ \\
\hline Financial Intermediaries & 1.8 & 2.0 & $5.1 *$ & 2012 & 10.5 & $0.53 \%$ \\
\hline Sudden Stop & $32.8 * * *$ & $13.5^{* * *}$ & $12.7 * * *$ & 2007 & 32.8 & $0.00 \%$ \\
\hline Liquidity & 4.2 & $6.2 * *$ & 2.7 & 2008 & 6.2 & $4.57 \%$ \\
\hline Sovereign Debt & $5.2 *$ & $5.2 *$ & $5.1^{*}$ & 2005 & 19.6 & $0.14 \%$ \\
\hline Emerging Markets & 1.1 & 0.3 & 0.2 & 2005 & 3.0 & $88.96 \%$ \\
\hline Great Recession & 3.1 & 3.1 & $12.5^{* * *}$ & 2010 & 12.6 & $3.19 \%$ \\
\hline Global Crisis & 8.3 & $23.7 * * *$ & $29.8^{* * *}$ & 2009 & 29.8 & $0.00 \%$ \\
\hline Repo and Securitization & 2.1 & $6.4 * *$ & $39.1 * * *$ & 2009 & 39.1 & $0.00 \%$ \\
\hline All NBER WPs & 1.0 & $6.7 * *$ & $29.1 * * *$ & 2009 & 29.1 & $0.00 \%$ \\
\hline
\end{tabular}

Note: The figures in the parentheses are the $t$-statistics. $* * * p<0.01, * * p<0.05, * p<0.10 . \mathrm{T}$

Table 11. Weights of the 9 crisis topics by NBER research programs

\begin{tabular}{|lcccccc|}
\hline & $\begin{array}{c}\text { Monetary } \\
\text { Economics }\end{array}$ & $\begin{array}{c}\text { Int. } \\
\text { Trade }\end{array}$ & $\begin{array}{c}\text { Corporate } \\
\text { Finance }\end{array}$ & $\begin{array}{c}\text { Asset } \\
\text { Pricing }\end{array}$ & $\begin{array}{c}\text { Int. Finance } \\
\text { and Macro }\end{array}$ & $\begin{array}{c}\text { Econ. Fluct. } \\
\text { and Growth }\end{array}$ \\
\hline International Reserves & $9 \%$ & $17 \%$ & $2 \%$ & $3 \%$ & $\mathbf{5 2 \%}$ & $7 \%$ \\
\hline Financial Intermediaries & $13 \%$ & $4 \%$ & $17 \%$ & $11 \%$ & $25 \%$ & $18 \%$ \\
\hline Sudden Stop & $5 \%$ & $5 \%$ & $1 \%$ & $3 \%$ & $\mathbf{6 2 \%}$ & $15 \%$ \\
\hline Liquidity & $15 \%$ & $1 \%$ & $22 \%$ & $32 \%$ & $11 \%$ & $12 \%$ \\
\hline Sovereign Debt & $13 \%$ & $2 \%$ & $8 \%$ & $5 \%$ & $\mathbf{3 8 \%}$ & $18 \%$ \\
\hline Emerging Markets & $10 \%$ & $7 \%$ & $4 \%$ & $4 \%$ & $\mathbf{4 3 \%}$ & $16 \%$ \\
\hline Great Recession & $18 \%$ & $2 \%$ & $4 \%$ & $5 \%$ & $14 \%$ & $27 \%$ \\
\hline Global Crisis & $19 \%$ & $4 \%$ & $11 \%$ & $8 \%$ & $\mathbf{3 3 \%}$ & $12 \%$ \\
\hline Repo and Securitization & $17 \%$ & $1 \%$ & $\mathbf{3 7 \%}$ & $24 \%$ & $4 \%$ & $8 \%$ \\
\hline \hline Average & $13 \%$ & $5 \%$ & $12 \%$ & $11 \%$ & $31 \%$ & $15 \%$ \\
\hline
\end{tabular}


Table 12. The average weights of 20 different topics in crisis WPs for the pre-crisis period (2005-2008), in the immediate post-crisis period (2009-2012), and in the post-crisis period (2013-2016)

\begin{tabular}{|c|c|c|c|c|c|c|}
\hline Topic name & $\begin{array}{c}\text { Pre- } \\
\text { Crisis: Av } \\
\text { 2005-2008 }\end{array}$ & $\begin{array}{l}\text { Crisis: } \\
\text { Av } \\
2009- \\
2012 \\
\end{array}$ & $\begin{array}{c}\text { Post- } \\
\text { Crisis: Av } \\
\text { 2013-2016 }\end{array}$ & $\begin{array}{l}\text { z-test for mean- } \\
\text { diff: pre-crisis vs } \\
\text { crisis }\end{array}$ & $\begin{array}{l}\text { z-test for mean- } \\
\text { diff: pre-crisis vs } \\
\text { post-crisis }\end{array}$ & $\begin{array}{l}\text { z-test for mean- } \\
\text { diff: crisis vs post- } \\
\text { crisis }\end{array}$ \\
\hline International Finance & 8.0 & 8.9 & 7.7 & 0.3 & -0.1 & -0.4 \\
\hline Sudden Stops & 9.5 & 3.2 & 2.3 & $-3.0 * * *$ & $-4.4 * * *$ & -0.5 \\
\hline Repo \& Securitization & 2.0 & 6.6 & 3.4 & $2.1 * *$ & 0.7 & -1.3 \\
\hline Liquidity & 3.6 & 4.4 & 4.5 & 0.4 & 0.4 & 0.1 \\
\hline Crisis Event & 3.2 & 5.3 & 4.7 & 1.0 & 0.6 & -0.3 \\
\hline Government Bailout & 4.7 & 2.7 & 4.4 & -1.2 & -0.1 & 1.1 \\
\hline History of Crisis & 6.1 & 6.3 & 5.4 & 0.1 & -0.3 & -0.4 \\
\hline International Reserves & 7.3 & 4.0 & 3.1 & -1.5 & $-2.2 * *$ & -0.5 \\
\hline Monetary Policy & 2.3 & 4.5 & 6.8 & 1.1 & $1.9 *$ & 1.2 \\
\hline Systemic Risk & 3.7 & 5.7 & 4.3 & 0.9 & 0.3 & -0.6 \\
\hline Exchange Rates & 4.5 & 3.4 & 4.1 & -0.6 & -0.2 & 0.4 \\
\hline Great Recessions & 2.3 & 5.4 & 7.8 & 1.5 & $2.2 * *$ & 1.1 \\
\hline Economic Shocks & 6.8 & 6.5 & 9.4 & -0.1 & 0.9 & 1.2 \\
\hline Economic Growth & 5.1 & 5.0 & 4.6 & -0.0 & -0.2 & -0.2 \\
\hline Sovereign Debt & 4.1 & 4.5 & 7.8 & 0.2 & 1.5 & 1.6 \\
\hline Banks & 3.7 & 5.1 & 4.9 & 0.7 & 0.5 & -0.1 \\
\hline Household Credit & 2.7 & 3.4 & 4.1 & 0.4 & 0.7 & 0.4 \\
\hline Asset Pricing & 4.9 & 6.2 & 4.1 & 0.6 & -0.3 & -0.9 \\
\hline Emerging Markets & 9.9 & 4.0 & 3.5 & $-2.6 * * *$ & $-3.3 * * *$ & -0.3 \\
\hline Currency Markets & 5.6 & 5.0 & 3.2 & -0.3 & -1.2 & -0.8 \\
\hline
\end{tabular}

Note: The table presents the average weights of topics identified by the LDA algorithm for 612 crisis WPs. We define a WP as a 'crisis WP' if (1) it includes the word crisis at least once in the first five paragraphs of the introduction, (2) crisis topics comprise at least $10 \%$ of the paper, and (3) crisis topics are among the top-three topics of the paper. Applying this definition, the algorithm identified 524 WPs, where 99 WPs were written in the pre-crisis period 2005-2009, 226 in the immediate post-crisis period 20092012, and 197 WPs in the post-crisis period 2008-2016. An increase in a topic weight with respect to the initial period is marked in boldface. 
Table 13. The 10 crisis topics identified by the LDA algorithm and the most frequent words in each topic, precrisis period (1999-2007)

\begin{tabular}{|l|llllllllll|}
\hline Topic & & \multicolumn{7}{|c|}{ The most frequent words in the topic } & economi & market \\
\hline Sudden & sudden & stop & model & larg & current & capit & account & emerg & economi \\
Stop & 357 & 337 & 133 & 125 & 112 & 106 & 105 & 94 & 92 & 87 \\
\hline Capital & capit & countri & growth & flow & develop & account & trade & liber & global & current \\
Flow & 403 & 300 & 180 & 163 & 155 & 142 & 121 & 104 & 92 & 91 \\
\hline Banking & bank & system & liquid & institut & risk & loan & deposit & sector & fund & bailout \\
System & 443 & 103 & 69 & 69 & 65 & 54 & 49 & 39 & 37 & 35 \\
\hline Foreign & currenc & countri & debt & state & market & period & global & recent & origin & differ \\
Debt & 161 & 128 & 98 & 92 & 81 & 69 & 66 & 61 & 59 & 57 \\
\hline Monetary & rate & polici & exchang & emerg & monetari & currenc & regim & economi & domest & interest \\
Policy & 340 & 282 & 220 & 143 & 141 & 112 & 98 & 96 & 95 & 79 \\
\hline Real & market & countri & differ & find & effect & time & aggreg & emerg & household & incom \\
Economy & 219 & 148 & 88 & 70 & 64 & 59 & 54 & 54 & 53 & 50 \\
\hline International & reserv & intern & countri & foreign & increas & develop & volatil & asian & east & manag \\
Reserves & 277 & 198 & 134 & 79 & 77 & 72 & 63 & 59 & 54 & 52 \\
\hline IMF & market & borrow & bond & countri & intern & imf & privat & lender & issu & restructur \\
Restructuring & 134 & 98 & 97 & 96 & 87 & 86 & 69 & 52 & 50 & 43 \\
\hline Liquidity & asset & liquid & Price & market & investor & guarante & trade & agent & risk & hazard \\
& 236 & 171 & 139 & 138 & 92 & 76 & 70 & 68 & 59 & 45 \\
\hline Sovereign & debt & default & govern & sovereign & model & increas & level & rate & interest & risk \\
Debt & 400 & 146 & 105 & 92 & 80 & 63 & 59 & 59 & 56 & 52 \\
\hline
\end{tabular}

Note: The corpus includes 165 NBER WPs. Words that do not appear in the pre-crisis period are marked in italic. The hyper-parameter values are set at $\alpha=0.1$ and $\beta=0.1$.

Table 14. The 10 crisis topics identified by the LDA algorithm and the most frequent words in each topic, postcrisis period (2008-2016)

\begin{tabular}{|l|llllllllll|}
\hline Topic & \multicolumn{9}{|c|}{ The most frequent words in the topic } & \\
\hline Currency & fiscal & currenc & union & euro & countri & european & govern & state & area & rate \\
Union & 206 & 181 & 117 & 116 & 114 & 108 & 88 & 87 & 82 & 80 \\
\hline Monetary & polici & monetari & rate & interest & model & view & economi & central & bubbl & real \\
Policy & 740 & 317 & 188 & 158 & 156 & 153 & 147 & 127 & 123 & 121 \\
\hline Credit & system & economi & credit & countri & boom & bank & advanc & unit & world & episod \\
Boom & 245 & 223 & 223 & 185 & 169 & 166 & 159 & 158 & 152 & 147 \\
\hline Sovereign & debt & default & govern & sovereign & public & bond & borrow & domest & privat & countri \\
Debt & 1,312 & 382 & 361 & 314 & 250 & 171 & 168 & 145 & 142 & 127 \\
\hline Liquidity & asset & market & liquid & price & risk & investor & valu & increas & return & equiti \\
& 736 & 525 & 426 & 392 & 321 & 251 & 172 & 172 & 157 & 142 \\
\hline Great & recess & great & Growth & rate & percent & declin & recoveri & incom & gdp & output \\
Recession & 413 & 306 & 255 & 203 & 187 & 183 & 175 & 149 & 148 & 145 \\
\hline Global & countri & global & Intern & market & capit & emerg & develop & foreign & economi & reserv \\
Markets & 802 & 433 & 423 & 420 & 377 & 327 & 303 & 252 & 251 & 234 \\
\hline Systemic & model & shock & sector & risk & system & capit & literatur & economi & measur & cost \\
Risk & 593 & 314 & 292 & 235 & 191 & 171 & 158 & 157 & 154 & 152 \\
\hline Federal & bank & federal & reserv & central & liquid & system & fund & deposit & provid & balanc \\
Reserve & 1,208 & 308 & 237 & 217 & 156 & 142 & 140 & 133 & 112 & 94 \\
\hline Banking & bank & credit & Loan & firm & securit & rate & corpor & mortgag & repo & collater \\
System & 398 & 373 & 340 & 308 & 290 & 258 & 219 & 197 & 111 & 110 \\
\hline
\end{tabular}

Note: The corpus includes 447 NBER WPs. Words that do not appear in the post-crisis period are marked in italic. The hyper-parameter values are set at $\alpha=0.1$ and $\beta=0.1$. 
APPENDIX A

SUPPLEMENTARY TABLES

Table 1A. NBER WPs, descriptive statistics for non-selected NBER programs, 1999-2016

\begin{tabular}{|l|c|c|c|c|c|c|c|c|c|c|c|c|c|c|c|c|}
\hline & DAE & CH & AG & ED & TWP & DEV & PR & POL & LE & EC & IO & PE & EEE & HE & IS & All \\
\hline Average number of WPs & 82 & 80 & 71 & 87 & 40 & 63 & 90 & 71 & 68 & 32 & 85 & 188 & 69 & 106 & 187 & 793 \\
\hline $\begin{array}{l}\text { Average number of WPs } \\
\text { before 2008 }\end{array}$ & 65 & 52 & 46 & 54 & 26 & 26 & 57 & 36 & 51 & 26 & 58 & 146 & 31 & 76 & 137 & 607 \\
\hline $\begin{array}{l}\text { Average number of WPs } \\
\text { after 2008 }\end{array}$ & 99 & 108 & 96 & 119 & 55 & 99 & 122 & 105 & 85 & 38 & 112 & 231 & 106 & 135 & 236 & 978 \\
\hline $\begin{array}{l}t \text {-test for difference in } \\
\text { mean }\end{array}$ & 12 & 21 & 18 & 24 & 11 & 25 & 23 & 26 & 12 & 4 & 20 & 26 & 27 & 20 & 30 & 55 \\
\hline Average number of WPs & 82 & 80 & 71 & 87 & 40 & 63 & 90 & 71 & 68 & 32 & 85 & 188 & 69 & 106 & 187 & 793 \\
\hline
\end{tabular}

Table 2A. Crisis WPs for non-selected NBER programs, descriptive statistics, 1999-2016

\begin{tabular}{|l|c|c|c|c|c|c|c|c|c|c|c|c|c|c|c|c|}
\hline & DAE & CH & AG & ED & TWP & DEV & PR & POL & LE & EC & IO & PE & EEE & HE & IS & All \\
\hline Average \% of crisis WPs & 13 & 3 & 6 & 3 & 5 & 6 & 4 & 6 & 5 & 5 & 4 & 5 & 5 & 4 & 4 & 11 \\
\hline Min. \% during 1999-2016 & 5 & 0 & 0 & 0 & 0 & 0 & 0 & 0 & 0 & 0 & 0 & 2 & 0 & 0 & 1 & 6 \\
\hline Max. \% during 1999-2016 & 21 & 12 & 17 & 17 & 17 & 17 & 11 & 17 & 15 & 17 & 14 & 11 & 17 & 10 & 8 & 18 \\
\hline Average \% before 2008 & 10 & 3 & 4 & 3 & 4 & 4 & 3 & 4 & 4 & 4 & 4 & 4 & 5 & 3 & 3 & 8 \\
\hline Average \% after 2008 & 17 & 4 & 8 & 4 & 5 & 7 & 6 & 9 & 7 & 6 & 5 & 7 & 5 & 5 & 5 & 14 \\
\hline (\% after)/(\%before) & 2 & 2 & 2 & 1 & 1 & 2 & 2 & 2 & 2 & 1 & 2 & 2 & 1 & 2 & 2 & 2 \\
\hline z-test for mean-difference & 4 & 2 & 3 & 0 & 1 & 2 & 3 & 3 & 2 & 1 & 2 & 4 & 0 & 2 & 3 & 10 \\
\hline \% out of all crisis WPs & 12 & 3 & 5 & 3 & 2 & 4 & 4 & 5 & 4 & 2 & 4 & 11 & 4 & 4 & 7 & 100 \\
\hline Number of crisis WPs & $\mathbf{2 0 4}$ & $\mathbf{6 6}$ & $\mathbf{8 8}$ & $\mathbf{6 0}$ & $\mathbf{5 1}$ & $\mathbf{7 5}$ & $\mathbf{8 5}$ & $\mathbf{1 0 0}$ & $\mathbf{7 9}$ & $\mathbf{4 9}$ & $\mathbf{8 3}$ & $\mathbf{1 8 8}$ & $\mathbf{7 2}$ & $\mathbf{8 3}$ & $\mathbf{1 2 8}$ & $\mathbf{1 , 6 3 2}$ \\
\hline
\end{tabular}


Table 7A. 20 topics identified by the LDA algorithm for the 612 crisis WPs

\begin{tabular}{|c|c|c|c|c|c|c|c|c|c|}
\hline \multicolumn{2}{|c|}{$\begin{array}{c}\text { International } \\
\text { Finance }\end{array}$} & \multicolumn{2}{c|}{ Sudden Stops } & \multicolumn{2}{c}{$\begin{array}{c}\text { Repo \& } \\
\text { Securitization }\end{array}$} & \multicolumn{2}{c|}{ Liquidity } & \multicolumn{2}{c|}{ Crisis Event } \\
\hline Words & Freq. & Words & Freq. & Words & Freq. & Words & Freq. & Words & Freq. \\
\hline differ & 0.08 & sudden & 0.14 & loan & 0.12 & liquid & 0.26 & failur & 0.08 \\
\hline find & 0.08 & stop & 0.12 & market & 0.11 & asset & 0.11 & event & 0.08 \\
\hline data & 0.06 & account & 0.10 & secur & 0.08 & market & 0.10 & lehman & 0.06 \\
\hline recent & 0.06 & current & 0.09 & credit & 0.07 & trade & 0.05 & view & 0.06 \\
\hline literatur & 0.06 & countri & 0.05 & securit & 0.06 & risk & 0.05 & led & 0.06 \\
\hline studi & 0.06 & capit & 0.05 & collater & 0.06 & demand & 0.04 & caus & 0.05 \\
\hline measur & 0.05 & larg & 0.04 & mortgag & 0.05 & illiquid & 0.04 & hous & 0.05 \\
\hline import & 0.05 & revers & 0.04 & lend & 0.05 & investor & 0.04 & septemb & 0.05 \\
\hline evid & 0.05 & deficit & 0.04 & bond & 0.05 & money & 0.04 & mani & 0.05 \\
\hline empir & 0.05 & emerg & 0.04 & rate & 0.05 & time & 0.04 & start & 0.05 \\
\hline time & 0.05 & net & 0.04 & repo & 0.04 & secur & 0.03 & effect & 0.05 \\
\hline countri & 0.05 & economi & 0.03 & corpor & 0.04 & increas & 0.03 & bankruptci & 0.04 \\
\hline effect & 0.04 & asset & 0.03 & agenc & 0.03 & suppli & 0.02 & time & 0.04 \\
\hline sever & 0.04 & global & 0.03 & borrow & 0.03 & treasuri & 0.02 & octob & 0.04 \\
\hline impact & 0.04 & extern & 0.03 & structur & 0.03 & bond & 0.02 & believ & 0.04 \\
\hline perform & 0.04 & imbal & 0.03 & fund & 0.03 & hold & 0.02 & feder & 0.04 \\
\hline relat & 0.04 & collaps & 0.03 & role & 0.03 & yield & 0.02 & rescu & 0.04 \\
\hline term & 0.04 & price & 0.03 & inform & 0.03 & spread & 0.02 & belief & 0.04 \\
\hline factor & 0.04 & adjust & 0.02 & origin & 0.03 & agent & 0.02 & bernank & 0.04 \\
\hline larg & 0.04 & market & 0.02 & subprim & 0.03 & particip & 0.02 & interest & 0.04 \\
\hline
\end{tabular}

\begin{tabular}{|c|c|c|c|c|c|c|c|c|c|}
\hline $\begin{array}{c}\text { Government } \\
\text { Bailout }\end{array}$ & \multicolumn{2}{c|}{ History of Crisis } & \multicolumn{2}{c|}{$\begin{array}{c}\text { International } \\
\text { Reserves }\end{array}$} & \multicolumn{2}{c|}{$\begin{array}{c}\text { Fiscal \& Monetary } \\
\text { Policy }\end{array}$} & \multicolumn{2}{c|}{ Systemic Risk } \\
\hline Words & Freq. & Words & Freq. & Words & Freq. & Words & Freq. & Words & Freq. \\
\hline borrow & 0.08 & system & 0.13 & reserv & 0.22 & polici & 0.22 & risk & 0.15 \\
\hline govern & 0.08 & state & 0.11 & countri & 0.12 & monetari & 0.13 & firm & 0.11 \\
\hline guarante & 0.07 & unit & 0.07 & intern & 0.11 & fiscal & 0.09 & system & 0.09 \\
\hline bailout & 0.06 & world & 0.06 & china & 0.05 & central & 0.07 & credit & 0.09 \\
\hline reform & 0.06 & gold & 0.06 & accumul & 0.04 & inflat & 0.05 & sector & 0.08 \\
\hline polici & 0.06 & histor & 0.05 & increas & 0.04 & stabil & 0.05 & regul & 0.06 \\
\hline imf & 0.06 & centuri & 0.05 & hold & 0.04 & respons & 0.04 & institut & 0.05 \\
\hline intern & 0.06 & histori & 0.05 & trade & 0.04 & union & 0.04 & market & 0.05 \\
\hline hazard & 0.05 & standard & 0.04 & global & 0.03 & target & 0.04 & govern & 0.04 \\
\hline privat & 0.05 & recent & 0.04 & foreign & 0.03 & credibl & 0.04 & measur & 0.03 \\
\hline moral & 0.04 & year & 0.04 & hoard & 0.03 & inat & 0.03 & economi & 0.03 \\
\hline problem & 0.04 & global & 0.04 & export & 0.03 & rule & 0.03 & corpor & 0.03 \\
\hline issu & 0.04 & depress & 0.04 & adjust & 0.03 & area & 0.03 & bank & 0.03 \\
\hline institut & 0.04 & bubbl & 0.04 & larg & 0.03 & euro & 0.02 & manag & 0.02 \\
\hline commit & 0.04 & great & 0.04 & cost & 0.03 & govern & 0.02 & claim & 0.02 \\
\hline intervent & 0.04 & center & 0.03 & extern & 0.03 & time & 0.02 & liabil & 0.02 \\
\hline lender & 0.03 & discuss & 0.03 & exchang & 0.03 & countri & 0.02 & analysi & 0.02 \\
\hline cost & 0.03 & section & 0.03 & associ & 0.03 & forecast & 0.02 & capit & 0.02 \\
\hline provid & 0.03 & event & 0.03 & asian & 0.03 & provid & 0.02 & inform & 0.02 \\
\hline program & 0.03 & today & 0.03 & develop & 0.02 & scal & 0.02 & contract & 0.02 \\
\hline
\end{tabular}




\begin{tabular}{|c|c|c|c|c|c|c|c|c|c|}
\hline \multicolumn{2}{|c|}{ Exchange Rates } & \multicolumn{2}{c|}{ Great Recession } & \multicolumn{2}{c|}{ Economic Shocks } & \multicolumn{2}{c|}{$\begin{array}{c}\text { Economic } \\
\text { Growth }\end{array}$} & \multicolumn{2}{c|}{ Sovereign Debt } \\
\hline Words & Freq. & Words & Freq. & Words & Freq. & Words & Freq. & Words & Freq. \\
\hline rate & 0.29 & recess & 0.15 & model & 0.28 & growth & 0.19 & debt & 0.36 \\
\hline exchang & 0.11 & great & 0.12 & shock & 0.10 & develop & 0.12 & default & 0.10 \\
\hline interest & 0.10 & recoveri & 0.07 & equilibrium & 0.05 & economi & 0.09 & govern & 0.08 \\
\hline polici & 0.09 & declin & 0.06 & constraint & 0.04 & countri & 0.08 & sovereign & 0.07 \\
\hline economi & 0.05 & output & 0.06 & product & 0.04 & gdp & 0.06 & public & 0.05 \\
\hline regim & 0.05 & percent & 0.05 & trade & 0.04 & sector & 0.06 & bond & 0.04 \\
\hline real & 0.05 & unemploy & 0.05 & show & 0.04 & advanc & 0.05 & matur & 0.03 \\
\hline increas & 0.03 & depress & 0.05 & optim & 0.04 & year & 0.04 & countri & 0.03 \\
\hline monetari & 0.03 & labor & 0.05 & friction & 0.04 & world & 0.04 & domest & 0.03 \\
\hline higher & 0.03 & period & 0.04 & studi & 0.04 & rate & 0.03 & borrow & 0.03 \\
\hline macroeconom & 0.02 & market & 0.04 & economi & 0.04 & percent & 0.03 & extern & 0.03 \\
\hline low & 0.02 & follow & 0.03 & effect & 0.04 & decad & 0.03 & risk & 0.02 \\
\hline inflat & 0.02 & downturn & 0.03 & invest & 0.03 & level & 0.02 & shortterm & 0.02 \\
\hline effect & 0.02 & year & 0.03 & dynam & 0.03 & increas & 0.02 & fiscal & 0.02 \\
\hline open & 0.02 & episod & 0.03 & literatur & 0.03 & sinc & 0.02 & ratio & 0.02 \\
\hline currenc & 0.02 & shock & 0.03 & lead & 0.03 & period & 0.02 & privat & 0.02 \\
\hline peg & 0.02 & employ & 0.03 & gener & 0.03 & averag & 0.02 & level & 0.02 \\
\hline stabil & 0.02 & chang & 0.03 & theori & 0.03 & invest & 0.02 & creditor & 0.02 \\
\hline combin & 0.02 & real & 0.03 & develop & 0.03 & share & 0.02 & spread & 0.01 \\
\hline level & 0.02 & rate & 0.03 & agent & 0.03 & neg & 0.02 & tax & 0.01 \\
\hline
\end{tabular}

\begin{tabular}{|c|c|c|c|c|c|c|c|c|c|}
\hline \multicolumn{2}{|c|}{ Banks } & \multicolumn{2}{c|}{ Household Credit } & \multicolumn{2}{c|}{ Asset Pricing } & \multicolumn{2}{c|}{ Emerging Market } & \multicolumn{2}{c|}{ Currency Market } \\
\hline Words & Freq. & Words & Freq. & Words & Freq. & Words & Freq. & Words & Freq. \\
\hline bank & 0.48 & credit & 0.19 & asset & 0.16 & capit & 0.17 & market & 0.16 \\
\hline central & 0.05 & boom & 0.11 & price & 0.15 & countri & 0.11 & currenc & 0.14 \\
\hline deposit & 0.04 & household & 0.10 & market & 0.10 & market & 0.10 & countri & 0.12 \\
\hline fund & 0.04 & incom & 0.08 & investor & 0.06 & intern & 0.08 & global & 0.09 \\
\hline lend & 0.04 & hous & 0.05 & capit & 0.05 & emerg & 0.07 & emerg & 0.08 \\
\hline reserv & 0.03 & show & 0.04 & fund & 0.05 & flow & 0.06 & shock & 0.05 \\
\hline feder & 0.03 & mortgag & 0.04 & equiti & 0.04 & trade & 0.04 & dollar & 0.04 \\
\hline run & 0.03 & busi & 0.04 & stock & 0.04 & develop & 0.04 & contagion & 0.04 \\
\hline institut & 0.03 & cycl & 0.04 & return & 0.04 & domest & 0.04 & foreign & 0.03 \\
\hline loan & 0.03 & increas & 0.03 & valu & 0.03 & foreign & 0.03 & intern & 0.03 \\
\hline provid & 0.03 & aggreg & 0.03 & larg & 0.03 & global & 0.03 & period & 0.03 \\
\hline system & 0.02 & leverag & 0.03 & risk & 0.03 & control & 0.03 & integr & 0.03 \\
\hline swap & 0.02 & borrow & 0.03 & sale & 0.03 & economi & 0.03 & spread & 0.02 \\
\hline oper & 0.02 & larg & 0.03 & expect & 0.03 & inflow & 0.03 & bank & 0.02 \\
\hline balanc & 0.02 & data & 0.03 & invest & 0.03 & latin & 0.03 & factor & 0.02 \\
\hline line & 0.02 & expans & 0.03 & portfolio & 0.03 & liber & 0.03 & exposur & 0.02 \\
\hline fed & 0.02 & save & 0.03 & crash & 0.02 & asian & 0.03 & origin & 0.02 \\
\hline insur & 0.02 & invest & 0.03 & increas & 0.02 & open & 0.02 & develop & 0.02 \\
\hline failur & 0.02 & tax & 0.03 & manag & 0.02 & extern & 0.02 & devalu & 0.02 \\
\hline larg & 0.02 & rise & 0.02 & sell & 0.02 & argentina & 0.02 & sever & 0.02 \\
\hline
\end{tabular}

Note: The table presents the words of the 20 topics identified by the LDA algorithm for the 612 crisis WPs. We define a WP as a 'crisis WP' if (1) it includes the word crisis at least once in the first five paragraphs of the introduction, (2) crisis topics comprise at least $10 \%$ of the paper, and (3) crisis topics are among the top-three topics of the paper. Applying this definition, the algorithm identified 612 WPs, where 189 WPs were written in the pre-crisis period 19992009, 226 during the crisis period 2009-2012, and 197 in the post-crisis period 2008-2016. 
Table 11A. Weights (in \%) of crisis topics by NBER research programs for non-selected programs

\begin{tabular}{|l|c|c|c|c|c|c|c|c|c|c|c|c|c|c|c|c|}
\hline \multicolumn{1}{|c|}{ Research topics } & DAE & CH & AG & ED & TWP & DEV & PR & POL & LE & EC & IO & PE & EEE & HE & IS & All \\
\hline International Reserves & 3 & 0 & 0 & 0 & 0 & 1 & 0 & 0 & 0 & 0 & 0 & 3 & 0 & 0 & 1 & 3 \\
\hline Financial Intermediaries & 3 & 0 & 0 & 0 & 0 & 1 & 2 & 1 & 2 & 0 & 1 & 1 & 0 & 0 & 1 & 3 \\
\hline Sudden Stop & 4 & 0 & 0 & 0 & 0 & 1 & 0 & 1 & 1 & 0 & 0 & 2 & 0 & 1 & 0 & 4 \\
\hline Liquidity & 1 & 0 & 1 & 0 & 0 & 0 & 0 & 0 & 1 & 0 & 1 & 1 & 0 & 0 & 1 & 1 \\
\hline Sovereign Debt & 4 & 0 & 1 & 0 & 0 & 0 & 1 & 1 & 1 & 0 & 0 & 7 & 0 & 0 & 0 & 4 \\
\hline Emerging Markets & 6 & 0 & 0 & 1 & 0 & 2 & 1 & 0 & 0 & 0 & 0 & 3 & 1 & 0 & 1 & 6 \\
\hline Great Recession & 7 & 0 & 1 & 0 & 0 & 0 & 4 & 1 & 0 & 0 & 0 & 3 & 0 & 1 & 9 & 7 \\
\hline Global Crisis & 9 & 0 & 0 & 0 & 0 & 0 & 0 & 1 & 0 & 0 & 0 & 2 & 0 & 0 & 1 & 9 \\
\hline Repo and Securitization & 3 & 0 & 0 & 0 & 0 & 1 & 0 & 0 & 0 & 0 & 0 & 3 & 0 & 0 & 1 & 3 \\
\hline
\end{tabular}

\section{Abbreviations used to denote the NBER research programs}

$\begin{array}{ll}\text { AE } & \text { Development of the American Economy } \\ \text { CH } & \text { Children } \\ \text { AG } & \text { Aging } \\ \text { ED } & \text { Economics of Education } \\ \text { TWP } & \text { Technical Working Papers } \\ \text { DEV } & \text { Development Economics } \\ \text { PR } & \text { Productivity, Innovation, and Entrepreneurship } \\ \text { POL } & \text { Political Economy } \\ \text { LE } & \text { Law and Economics } \\ \text { EC } & \text { Health Care } \\ \text { IO } & \text { Industrial Organization } \\ \text { PE } & \text { Public Economics } \\ \text { EEE } & \text { Environment and Energy Economics } \\ \text { IFM } & \text { International Finance and Macroeconomics } \\ \text { HE } & \text { Health Economics } \\ \text { IS } & \text { Labor Studies } \\ \text { EFG } & \text { Economic Fluctuations and Growth } \\ \text { All } & \text { All NBER WP }\end{array}$




\section{APPENDIX B}

\section{TOP-20 WPS WITH THE HIGHEST PROBABILITY, FOR EACH CRISIS WP}

\section{Top-20 WPs on the topic of 'Global Crisis'}

\begin{tabular}{|c|c|c|c|c|c|c|}
\hline & Title & Year & $\begin{array}{l}\% \text { of } \\
\text { topic }\end{array}$ & $\begin{array}{l}\% \text { of } \\
\text { crisis } \\
\text { topics }\end{array}$ & Programs & Authors \\
\hline 1 & $\begin{array}{l}\text { The Center and the Periphery: The } \\
\text { Globalization of Financial Turmoil }\end{array}$ & 2003 & $57 \%$ & $57 \%$ & 1. IFM & Kaminsy and Reinhart \\
\hline 2 & The Great Depression Analogy & 2009 & $52 \%$ & $52 \%$ & $\begin{array}{l}\text { 1. ME } \\
\text { 2. DAE }\end{array}$ & Bordo and James \\
\hline 3 & $\begin{array}{l}\text { U.S. Banks, Crises, and Bailouts: From } \\
\text { Mexico to LTCM }\end{array}$ & 2000 & $49 \%$ & $49 \%$ & $\begin{array}{l}\text { 1. } \mathrm{CF} \\
\text { 2. IFM } \\
\text { 3. } \mathrm{ME}\end{array}$ & Stulz \\
\hline 4 & $\begin{array}{l}\text { Over The Cliff: From the Subprime to } \\
\text { the Global Financial Crisis }\end{array}$ & 2010 & $47 \%$ & $49 \%$ & $\begin{array}{l}\text { 1. } \mathrm{EFG} \\
\text { 2. } \mathrm{ME}\end{array}$ & Mishkin \\
\hline 5 & $\begin{array}{l}\text { Three Branches of Theories of } \\
\text { Financial Crises }\end{array}$ & 2013 & $47 \%$ & $47 \%$ & 1. IFM & Goldstein and Razin \\
\hline 6 & $\begin{array}{l}\text { Transmission of the U.S. Subprime } \\
\text { Crisis to Emerging Markets: Evidence } \\
\text { on the Decoupling-Recoupling } \\
\text { Hypothesis }\end{array}$ & 2009 & $46 \%$ & $68 \%$ & 1. IFM & Dooley and Hutchison \\
\hline 7 & The Flight from Maturity & 2014 & $45 \%$ & $45 \%$ & $\begin{array}{l}\text { 1. } \mathrm{AP} \\
\text { 2. } \mathrm{ME} \\
\text { 3. } \mathrm{CF} \\
\text { 4. } \mathrm{EFG} \\
\end{array}$ & Gorton, Metrick, and Xie \\
\hline 8 & $\begin{array}{l}\text { The Global Financial Crisis of 2007- } \\
\text { 08: Is it Unprecedented? }\end{array}$ & 2010 & $44 \%$ & $54 \%$ & $\begin{array}{l}\text { 1. DAE } \\
\text { 2. ME }\end{array}$ & Bordo, Landon-Lee \\
\hline 9 & $\begin{array}{l}\text { Deciphering the Liquidity and Credit } \\
\text { Crunch 2007-08 }\end{array}$ & 2008 & $44 \%$ & $57 \%$ & $\begin{array}{l}\text { 1. IFM } \\
\text { 2. } \mathrm{ME} \\
\text { 3. } \mathrm{CF} \\
\text { 4. } \mathrm{EFG} \\
\text { 5. AP }\end{array}$ & Brunnermeier \\
\hline 10 & Fiscal and Financial Crises & 2016 & $42 \%$ & $42 \%$ & $\begin{array}{l}\text { 1. DAE } \\
\text { 2. IFM } \\
\text { 3. ME }\end{array}$ & Bordo and Meissner \\
\hline 11 & $\begin{array}{l}\text { An Historical Perspective on the Crisis } \\
\text { of 2007-2008 }\end{array}$ & 2008 & $41 \%$ & $44 \%$ & 1. ME & Bordo \\
\hline 12 & $\begin{array}{l}\text { Getting up to Speed on the Financial } \\
\text { Crisis: A One-Weekend-Reader's } \\
\text { Guide }\end{array}$ & 2012 & $41 \%$ & $41 \%$ & $\begin{array}{l}\text { 1. } \mathrm{AP} \\
\text { 2. } \mathrm{ME} \\
\text { 3. } \mathrm{CF}\end{array}$ & Gorton and Metrick \\
\hline 13 & $\begin{array}{l}\text { Crises in the Global Economy from } \\
\text { Tulips to Today: Contagion and } \\
\text { Consequences }\end{array}$ & 2002 & $40 \%$ & $40 \%$ & $\begin{array}{l}\text { 1. DAE } \\
\text { 2. IFM }\end{array}$ & Neal and Weidenmier \\
\hline 14 & $\begin{array}{l}\text { The Credit Crisis: Conjectures about } \\
\text { Causes and Remedies }\end{array}$ & 2009 & $39 \%$ & $39 \%$ & $\begin{array}{l}\text { 1. IFM } \\
\text { 2. } \mathrm{ME} \\
\text { 3. } \mathrm{CF} \\
\text { 4. } \mathrm{AP} \\
\end{array}$ & Diamond and Rajan \\
\hline 15 & $\begin{array}{l}\text { Bubbles, Financial Crises, and } \\
\text { Systemic Risk }\end{array}$ & 2012 & $39 \%$ & $42 \%$ & $\begin{array}{l}\text { 1. } \mathrm{CF} \\
\text { 2. } \mathrm{ME} \\
\text { 3. } \mathrm{AP}\end{array}$ & Brunnermeier and Oehmke \\
\hline
\end{tabular}




\begin{tabular}{|c|c|c|c|c|c|c|}
\hline 16 & $\begin{array}{l}\text { Some Reflections on the Recent } \\
\text { Financial Crisis }\end{array}$ & 2012 & $38 \%$ & $52 \%$ & $\begin{array}{l}\text { 1. } \mathrm{AP} \\
\text { 2. } \mathrm{ME} \\
\text { 3. } \mathrm{CF} \\
\text { 4. } \mathrm{EFG}\end{array}$ & Gorton \\
\hline 17 & $\begin{array}{l}\text { How the Subprime Crisis Went Global: } \\
\text { Evidence from Bank Credit Default } \\
\text { Swap Spreads }\end{array}$ & 2009 & $37 \%$ & $37 \%$ & $\begin{array}{l}\text { 1. ITI } \\
\text { 2. ME } \\
\text { 3. EFG }\end{array}$ & $\begin{array}{l}\text { Eichengreen, Mody, } \\
\text { Nedeljkovic, and Sarno }\end{array}$ \\
\hline 18 & $\begin{array}{l}\text { Crises Now and Then: What Lessons } \\
\text { from the Last Era of Financial } \\
\text { Globalization }\end{array}$ & 2002 & $36 \%$ & $64 \%$ & $\begin{array}{l}\text { 1. DAE } \\
\text { 2. IFM } \\
\text { 3. ME }\end{array}$ & Eichengreen and Bordo \\
\hline 19 & $\begin{array}{l}\text { Financial Crises and Economic } \\
\text { Activity }\end{array}$ & 2009 & $36 \%$ & $43 \%$ & 1. $\mathrm{ME}$ & $\begin{array}{l}\text { Cecchetti, Kohler, and } \\
\text { Upper }\end{array}$ \\
\hline 20 & $\begin{array}{l}\text { A Fiscal Union for the Euro: Some } \\
\text { Lessons from History }\end{array}$ & 2011 & $36 \%$ & $43 \%$ & $\begin{array}{l}\text { 1. DAE } \\
\text { 2. ME }\end{array}$ & $\begin{array}{l}\text { Bordo, Markiewicz, and } \\
\text { Jonung }\end{array}$ \\
\hline
\end{tabular}

\section{Top-20 WPs on the topic of 'Sudden Stops'}

\begin{tabular}{|c|c|c|c|c|c|c|}
\hline & Title & Year & $\begin{array}{l}\text { \% of } \\
\text { topic }\end{array}$ & $\begin{array}{l}\% \text { of } \\
\text { crisis } \\
\text { topics }\end{array}$ & Programs & Authors \\
\hline 1 & Sudden Flight and True Sudden Stops & 2006 & $46 \%$ & $46 \%$ & 1. IFM & Rothenberg and Warnock \\
\hline 2 & $\begin{array}{l}\text { Are Asset Price Guarantees Useful for } \\
\text { Preventing Sudden Stops?: A } \\
\text { Quantitative Investigation of the } \\
\text { Globalization Hazard-Moral Hazard } \\
\text { Tradeoff }\end{array}$ & 2005 & $45 \%$ & $45 \%$ & 1. IFM & Durdo and Mendoza \\
\hline 3 & $\begin{array}{l}\text { On the Empirics of Sudden Stops: The } \\
\text { Relevance of Balance-Sheet Effects }\end{array}$ & 2004 & $41 \%$ & $41 \%$ & 1. IFM & $\begin{array}{l}\text { Calvo, Izquierdo, and } \\
\text { Mejia }\end{array}$ \\
\hline 4 & Sudden Stops and Output Drops & 2005 & $40 \%$ & $40 \%$ & $\begin{array}{l}\text { 1. IFM } \\
\text { 2. EFG }\end{array}$ & $\begin{array}{l}\text { Chari, Keohoe, and } \\
\text { McGratten }\end{array}$ \\
\hline 5 & $\begin{array}{l}\text { Sudden Stops: Determinants and } \\
\text { Output Effects in the First Era of } \\
\text { Globalization, 1880-1913 }\end{array}$ & 2007 & $36 \%$ & $43 \%$ & $\begin{array}{l}\text { 1. IFM } \\
\text { 2. DAE }\end{array}$ & $\begin{array}{l}\text { Bordo, Cavallo, and } \\
\text { Meissner }\end{array}$ \\
\hline 6 & $\begin{array}{l}\text { Margin Calls, Trading Costs, and Asset } \\
\text { Prices in Emerging Markets: The } \\
\text { Financial Mechanics of the 'Sudden } \\
\text { Stop' Phenomenon }\end{array}$ & 2002 & $35 \%$ & $47 \%$ & 1. IFM & Mendoza and Smith \\
\hline 7 & $\begin{array}{l}\text { Putting the Brakes on Sudden Stops: } \\
\text { The Financial Frictions-Moral Hazard } \\
\text { Tradeoff of Asset Price Guarantees }\end{array}$ & 2004 & $33 \%$ & $40 \%$ & 1. IFM & Mendoza and Durdo \\
\hline 8 & $\begin{array}{l}\text { Fear of Sudden Stops: Lessons from } \\
\text { Australia and Chile }\end{array}$ & 2004 & $33 \%$ & $33 \%$ & $\begin{array}{l}\text { 1. EFG } \\
\text { 2. IFM }\end{array}$ & $\begin{array}{l}\text { Caballero, Cowan, and } \\
\text { Kearns }\end{array}$ \\
\hline 9 & $\begin{array}{l}\text { Systemic Sudden Stops: The Relevance } \\
\text { Of Balance-Sheet Effects And } \\
\text { Financial Integration }\end{array}$ & 2008 & $32 \%$ & $35 \%$ & 1. IFM & $\begin{array}{l}\text { Calvo, Izquierdo, and } \\
\text { Mejia }\end{array}$ \\
\hline 10 & $\begin{array}{l}\text { Sudden Stops, Financial Crises and } \\
\text { Leverage: A Fisherian Deflation of } \\
\text { Tobin's Q }\end{array}$ & 2008 & $31 \%$ & $31 \%$ & 1. IFM & Mendoza \\
\hline 11 & $\begin{array}{l}\text { Lessons From the Debt-Deflation } \\
\text { Theory of Sudden Stops }\end{array}$ & 2006 & $30 \%$ & $30 \%$ & 1. IFM & Mendoza \\
\hline
\end{tabular}




\begin{tabular}{|c|c|c|c|c|c|c|}
\hline 12 & $\begin{array}{l}\text { Sudden Stops, the Real Exchange Rate, } \\
\text { and Fiscal Sustainability: Argentina's } \\
\text { Lessons }\end{array}$ & 2003 & $28 \%$ & $28 \%$ & 1. IFM & $\begin{array}{l}\text { Calvo, Izquierdo, and } \\
\text { Talvi }\end{array}$ \\
\hline 13 & $\begin{array}{l}\text { Capital Flow Bonanzas: An } \\
\text { Encompassing View of the Past and } \\
\text { Present }\end{array}$ & 2008 & $28 \%$ & $41 \%$ & 1. IFM & Reinhart and Reinhart \\
\hline 14 & $\begin{array}{l}\text { Sudden Stops and IMF-Supported } \\
\text { Programs }\end{array}$ & 2006 & $27 \%$ & $35 \%$ & 1. IFM & $\begin{array}{l}\text { Eichengreen, Gupta, and } \\
\text { Mody }\end{array}$ \\
\hline 15 & $\begin{array}{l}\text { Monetary Unions, External Shocks and } \\
\text { Economic Performance: A Latin } \\
\text { American Perspective }\end{array}$ & 2006 & $27 \%$ & $27 \%$ & 1. IFM & Edwards \\
\hline 16 & $\begin{array}{l}\text { Does Openness to Trade Make } \\
\text { Countries More Vulnerable to Sudden } \\
\text { Stops, Or Less? Using Gravity to } \\
\text { Establish Causality }\end{array}$ & 2004 & $27 \%$ & $30 \%$ & $\begin{array}{l}\text { 1. DEV } \\
\text { 2. IFM }\end{array}$ & Frankel and Cavallo \\
\hline 17 & $\begin{array}{l}\text { Quantitative Implication of A Debt- } \\
\text { Deflation Theory of Sudden Stops and } \\
\text { Asset Prices }\end{array}$ & 2004 & $26 \%$ & $28 \%$ & 1. IFM & Mendoza and Smith \\
\hline 18 & $\begin{array}{l}\text { Endogenous Sudden Stops in a } \\
\text { Business Cycle Model with Collateral } \\
\text { Constraints: A Fisherian Deflation of } \\
\text { Tobin's Q }\end{array}$ & 2006 & $26 \%$ & $27 \%$ & $\begin{array}{l}\text { 1. DEV } \\
\text { 2. IFM }\end{array}$ & Mendoza \\
\hline 19 & $\begin{array}{l}\text { Financial Openness, Sudden Stops and } \\
\text { Current Account Reversals }\end{array}$ & 2004 & $25 \%$ & $26 \%$ & 1. IFM & Edwards \\
\hline 20 & $\begin{array}{l}\text { Crises and Sudden Stops: Evidence } \\
\text { from International Bond and } \\
\text { Syndicated-Loan Markets }\end{array}$ & 2008 & $25 \%$ & $50 \%$ & 1. IFM & Kaminsky \\
\hline
\end{tabular}

\section{Top-20 WPs on the topic of 'Financial Intermediaries'}

\begin{tabular}{|c|c|c|c|c|c|c|}
\hline & Title & Year & $\begin{array}{l}\% \text { of } \\
\text { topic }\end{array}$ & $\begin{array}{l}\% \text { of } \\
\text { crisis } \\
\text { topics }\end{array}$ & Programs & Authors \\
\hline 1 & $\begin{array}{l}\text { Financial Development in } 205 \\
\text { Economies, } 1960 \text { to } 2010\end{array}$ & 2013 & $47 \%$ & $47 \%$ & $\begin{array}{l}\text { 1. CF } \\
\text { 2. DEV } \\
\text { 3. EFG } \\
\text { 4. IFM } \\
\end{array}$ & $\begin{array}{l}\text { Čihák, Demirgüč- } \\
\text { Kunt, Feyen, and Levine }\end{array}$ \\
\hline 2 & Financial Intermediation & 2002 & $45 \%$ & $53 \%$ & 1. CF & Gorton and Winton \\
\hline 3 & Growing Up to Financial Stability & 2007 & $45 \%$ & $45 \%$ & $\begin{array}{l}\text { 1. IFM } \\
\text { 2. ME } \\
\text { 3. DAE }\end{array}$ & Bordo \\
\hline 4 & $\begin{array}{l}\text { International Channels of Transmission } \\
\text { of Monetary Policy and the Mundellian } \\
\text { Trilemma }\end{array}$ & 2016 & $39 \%$ & $39 \%$ & $\begin{array}{l}\text { 1. IFM } \\
\text { 2. ME } \\
\text { 3. AP }\end{array}$ & Rey \\
\hline 5 & $\begin{array}{l}\text { Industry Growth and Capital } \\
\text { Allocation: Does Having a Market- or } \\
\text { Bank-Based System Matter? }\end{array}$ & 2002 & $38 \%$ & $38 \%$ & $\begin{array}{l}\text { 1. CF } \\
\text { 2. } \mathrm{AG}\end{array}$ & Beck and Levine \\
\hline 6 & $\begin{array}{l}\text { The Redistributive Effects of Financial } \\
\text { Deregulation }\end{array}$ & 2013 & $36 \%$ & $36 \%$ & $\begin{array}{l}\text { 1. CF } \\
\text { 2. DEV } \\
\text { 3. IFM }\end{array}$ & Korinek and Kreamer \\
\hline
\end{tabular}




\begin{tabular}{|c|c|c|c|c|c|c|}
\hline 7 & $\begin{array}{l}\text { The Great Reversals: The Politics of } \\
\text { Financial Development in the 20th } \\
\text { Century }\end{array}$ & 2001 & $35 \%$ & $35 \%$ & 1. $\mathrm{CF}$ & Rajan and Zingales \\
\hline 8 & $\begin{array}{l}\text { Risk Bearing, Implicit Financial } \\
\text { Services and Specialization in the } \\
\text { Financial Industry }\end{array}$ & 2008 & $33 \%$ & $33 \%$ & 1. $\mathrm{PR}$ & Wang and Basu \\
\hline 9 & $\begin{array}{l}\text { Financial Sector Regulation and } \\
\text { Reforms in Emerging Markets: An } \\
\text { Overview }\end{array}$ & 2010 & $31 \%$ & $39 \%$ & 1. IFM & Prasad \\
\hline 10 & $\begin{array}{l}\text { The Integrated Financial and Real } \\
\text { System of National Accounts for the } \\
\text { United States: Does It Presage the } \\
\text { Financial Crisis? }\end{array}$ & 2009 & $30 \%$ & $34 \%$ & $\begin{array}{l}\text { 1. IFM } \\
\text { 2. ME } \\
\text { 3. AP }\end{array}$ & Palumbo and Parker \\
\hline 11 & $\begin{array}{l}\text { Legal Institutions and Financial } \\
\text { Development }\end{array}$ & 2004 & $29 \%$ & $29 \%$ & $\begin{array}{l}\text { 1. CF } \\
\text { 2. LE }\end{array}$ & Beck and Levine \\
\hline 12 & $\begin{array}{l}\text { What Matters for Financial } \\
\text { Development? Capital Controls, } \\
\text { Institutions, and Interactions }\end{array}$ & 2005 & $29 \%$ & $35 \%$ & 1. IFM & Chinn and Ito \\
\hline 13 & The Financial Sector in Burundi & 2012 & $28 \%$ & $28 \%$ & 1. IFM & $\begin{array}{l}\text { Nkurunziza, Ndikuman, } \\
\text { and Nyamoya }\end{array}$ \\
\hline 14 & $\begin{array}{l}\text { China's Financial System: } \\
\text { Opportunities and Challenges }\end{array}$ & 2012 & $27 \%$ & $37 \%$ & 1. $\mathrm{CF}$ & $\begin{array}{l}\text { Allen, Qian, Zhang and } \\
\text { Zhao }\end{array}$ \\
\hline 15 & $\begin{array}{l}\text { Two Centuries of Finance and Growth } \\
\text { in the United States, 1790-1980 }\end{array}$ & 2016 & $27 \%$ & $40 \%$ & 1. DAE & Bodenhorn \\
\hline 16 & $\begin{array}{l}\text { Macroeconomics with Financial } \\
\text { Frictions: A Survey }\end{array}$ & 2012 & $27 \%$ & $38 \%$ & $\begin{array}{l}\text { 1. CF } \\
\text { 2. } \mathrm{DEV} \\
\text { 3. EFG } \\
\text { 4. IFM } \\
\text { 5. AP }\end{array}$ & $\begin{array}{l}\text { Brunnermeier, Eisenbach, } \\
\text { and Sannikov }\end{array}$ \\
\hline 17 & $\begin{array}{l}\text { Credit Constraints, Heterogeneous } \\
\text { Firms, and International Trade }\end{array}$ & 2008 & $27 \%$ & $27 \%$ & 1. ITI & Manova \\
\hline 18 & $\begin{array}{l}\text { Transparency, Risk Management and } \\
\text { International Financial Fragility }\end{array}$ & 2003 & $26 \%$ & $26 \%$ & 1. $\mathrm{CF}$ & $\begin{array}{l}\text { Draghi, Giavazzi, and } \\
\text { Merton }\end{array}$ \\
\hline 19 & $\begin{array}{l}\text { Risky Investments with Limited } \\
\text { Commitment }\end{array}$ & 2013 & $26 \%$ & $26 \%$ & 1. IFM & $\begin{array}{l}\text { Cooley, Marimon, and } \\
\text { Quadrini }\end{array}$ \\
\hline 20 & $\begin{array}{l}\text { Financial Development and Output } \\
\text { Growth in Developing Asia and Latin } \\
\text { America: A Comparative Sectoral } \\
\text { Analysis }\end{array}$ & 2015 & $26 \%$ & $26 \%$ & 1. DEV & $\begin{array}{l}\text { Aizenman, Jinjarak, and } \\
\text { Park }\end{array}$ \\
\hline
\end{tabular}

\section{Top-20 WPs on the topic of 'International Reserves'}

\begin{tabular}{|c|l|c|c|c|c|l|}
\hline \multicolumn{1}{|c|}{ Title } & Year & $\begin{array}{c}\text { \% of } \\
\text { topic }\end{array}$ & $\begin{array}{c}\text { \% of } \\
\text { crisis } \\
\text { topics }\end{array}$ & Programs & Authors \\
\hline 1 & $\begin{array}{l}\text { For a Few Dollars More: Reserves and } \\
\text { Growth in Times of Crises }\end{array}$ & 2014 & $57 \%$ & $57 \%$ & 1. IFM & $\begin{array}{l}\text { Bussière, Cheng, Chinn } \\
\text { and Lisack }\end{array}$ \\
\hline
\end{tabular}




\begin{tabular}{|c|c|c|c|c|c|c|}
\hline 2 & $\begin{array}{l}\text { Financial Versus Monetary } \\
\text { Mercantilism-Long-run View of Large } \\
\text { International Reserves Hoarding }\end{array}$ & 2006 & $57 \%$ & $57 \%$ & $\begin{array}{l}\text { 1. IFM } \\
\text { 2. ITI }\end{array}$ & Aizenman and Lee \\
\hline 3 & $\begin{array}{l}\text { International Reserves Management } \\
\text { and the Current Account }\end{array}$ & 2006 & $54 \%$ & $59 \%$ & $\begin{array}{l}\text { 1. IFM } \\
\text { 2. ITI }\end{array}$ & Aizenman \\
\hline 4 & $\begin{array}{l}\text { The financial crisis and sizable } \\
\text { international reserves depletion: From } \\
\text { 'fear of floating' to the 'fear of losing } \\
\text { international reserves'? }\end{array}$ & 2009 & $51 \%$ & $51 \%$ & $\begin{array}{l}\text { 1. IFM } \\
\text { 2. ITI }\end{array}$ & Aizenman and Sun \\
\hline 5 & $\begin{array}{l}\text { Large Hoarding of International } \\
\text { Reserves and the Emerging Global } \\
\text { Economic Architecture }\end{array}$ & 2007 & $51 \%$ & $53 \%$ & 1. ITI & Aizenman \\
\hline 6 & $\begin{array}{l}\text { International Reserve Holdings with } \\
\text { Sovereign Risk and Costly Tax } \\
\text { Collection }\end{array}$ & 2002 & $46 \%$ & $50 \%$ & 1. ITI & Aizenman and Marion \\
\hline 7 & $\begin{array}{l}\text { The High Demand for International } \\
\text { Reserves in the Far East: What's Going } \\
\text { On? }\end{array}$ & 2002 & $45 \%$ & $45 \%$ & 1. IFM & Aizenman and Marion \\
\hline 8 & $\begin{array}{l}\text { International Reserves: Precautionary } \\
\text { versus Mercantilist Views, Theory and } \\
\text { Evidence }\end{array}$ & 2005 & $44 \%$ & $54 \%$ & $\begin{array}{l}\text { 1. IFM } \\
\text { 2. ITI }\end{array}$ & Aizenman and Lee \\
\hline 9 & $\begin{array}{l}\text { International Reserves Management } \\
\text { and Capital Mobility in a Volatile } \\
\text { World: Policy Considerations and a } \\
\text { Case Study of Korea }\end{array}$ & 2004 & $43 \%$ & $49 \%$ & $\begin{array}{l}\text { 1. IFM } \\
\text { 2. ITI }\end{array}$ & Aizenman, Lee, and Rhee \\
\hline 10 & $\begin{array}{l}\text { International Reserves and the Global } \\
\text { Financial Crisis }\end{array}$ & 2011 & $41 \%$ & $41 \%$ & 1. IFM & $\begin{array}{l}\text { Dominguez, } \\
\text { Hashimoto, and Ito }\end{array}$ \\
\hline 11 & $\begin{array}{l}\text { The Social Cost of Foreign Exchange } \\
\text { Reserves }\end{array}$ & 2006 & $38 \%$ & $48 \%$ & 1. IFM & Rodrik \\
\hline 12 & $\begin{array}{l}\text { Financial Stability, the Trilemma, and } \\
\text { International Reserves }\end{array}$ & 2008 & $38 \%$ & $38 \%$ & 1. IFM & $\begin{array}{l}\text { Obstfeld, Shambaugh, and } \\
\text { Taylor }\end{array}$ \\
\hline 13 & $\begin{array}{l}\text { International Reserves and Rollover } \\
\text { Risk }\end{array}$ & 2012 & $35 \%$ & $35 \%$ & $\begin{array}{l}\text { 1. IFM } \\
\text { 2. EFG }\end{array}$ & $\begin{array}{l}\text { Bianchi, Hatchondo, and } \\
\text { Martinez }\end{array}$ \\
\hline 14 & $\begin{array}{l}\text { International reserves and swap lines: } \\
\text { substitutes or complements? }\end{array}$ & 2010 & $37 \%$ & $37 \%$ & $\begin{array}{l}\text { 1. IFM } \\
\text { 2. ITI }\end{array}$ & $\begin{array}{l}\text { Aizenman, Jinjarak, and } \\
\text { Park }\end{array}$ \\
\hline 15 & $\begin{array}{l}\text { Liquidity and Foreign Asset } \\
\text { Management Challenges for Latin } \\
\text { American Countries }\end{array}$ & 2014 & $37 \%$ & $43 \%$ & 1. IFM & $\begin{array}{l}\text { Aizenman and Riera- } \\
\text { Crichton }\end{array}$ \\
\hline 16 & $\begin{array}{l}\text { China's Growth, Stability, and Use of } \\
\text { International Reserves }\end{array}$ & 2013 & $35 \%$ & $35 \%$ & 1. IFM & $\begin{array}{l}\text { Aizenman, Jinjarak, and } \\
\text { Marion }\end{array}$ \\
\hline 17 & $\begin{array}{l}\text { Financial Instability, Reserves, and } \\
\text { Central Bank Swap Lines in the Panic } \\
\text { of } 2008\end{array}$ & 2009 & $35 \%$ & $34 \%$ & 1. IFM & $\begin{array}{l}\text { Obstfeld, Shambaugh, and } \\
\text { Taylor }\end{array}$ \\
\hline 18 & $\begin{array}{l}\text { Exchange Market Pressure and } \\
\text { Absorption by International Reserves: } \\
\text { Emerging Markets and Fear of Reserve } \\
\text { Loss During the 2008-09 Crisis }\end{array}$ & 2010 & $35 \%$ & $34 \%$ & $\begin{array}{l}\text { 1. IFM } \\
\text { 2. EFG }\end{array}$ & Aizenman and Hutchison \\
\hline 19 & $\begin{array}{l}\text { Optimal Reserves in Financially } \\
\text { Closed Economies }\end{array}$ & 2016 & $34 \%$ & $42 \%$ & 1. IFM & Jeanne and Sandri \\
\hline
\end{tabular}




\begin{tabular}{|c|l|c|c|c|c|l|}
\hline 20 & $\begin{array}{l}\text { Sterilization, Monetary Policy, and } \\
\text { Global Financial Integration }\end{array}$ & 2008 & $34 \%$ & $35 \%$ & 1. IFM & Aizenman and Glick \\
\hline
\end{tabular}

\section{Top-20 WPs on the topic of 'Liquidity'}

\begin{tabular}{|c|c|c|c|c|c|c|}
\hline & Title & Year & $\begin{array}{l}\% \text { of } \\
\text { topic }\end{array}$ & $\begin{array}{l}\% \text { of } \\
\text { crisis } \\
\text { topics }\end{array}$ & Programs & Authors \\
\hline 1 & Outside and Inside Liquidity & 2009 & $43 \%$ & $43 \%$ & $\begin{array}{l}\text { 1. } \mathrm{AP} \\
\text { 2. } \mathrm{CF}\end{array}$ & $\begin{array}{l}\text { Bolton, Santos, and } \\
\text { Scheinkman }\end{array}$ \\
\hline 2 & $\begin{array}{l}\text { Flight to Quality, Flight to Liquidity, } \\
\text { and the Pricing of Risk }\end{array}$ & 2004 & $43 \%$ & $43 \%$ & 1. AP & Vayanos \\
\hline 3 & Portfolio Choice with Illiquid Assets & 2013 & $42 \%$ & $42 \%$ & 1. AP & $\begin{array}{l}\text { Ang, Papanikolaou, and } \\
\text { Westerfield }\end{array}$ \\
\hline 4 & Valuing Thinly-Traded Assets & 2014 & $40 \%$ & $41 \%$ & 1. AP & Longstaff \\
\hline 5 & Predatory Trading & 2004 & $37 \%$ & $39 \%$ & 1. AP & Brunnermeier and Pedersen \\
\hline 6 & Financial Market Runs & 2002 & $37 \%$ & $37 \%$ & $\begin{array}{l}\text { 1. } \mathrm{AP} \\
\text { 2. } \mathrm{CF}\end{array}$ & Bernardo and Welch \\
\hline 7 & $\begin{array}{l}\text { Market Liquidity and Funding } \\
\text { Liquidity }\end{array}$ & 2007 & $36 \%$ & $36 \%$ & $\begin{array}{l}\text { 1. } \mathrm{AP} \\
\text { 2. } \mathrm{CF}\end{array}$ & Brunnermeier and Pedersen \\
\hline 8 & Liquidity and Market Crashes & 2008 & $34 \%$ & $35 \%$ & 1. AP & Huang and Wang \\
\hline 9 & $\begin{array}{l}\text { Liquidity, Efficiency and Bank } \\
\text { Bailouts }\end{array}$ & 2002 & $34 \%$ & $34 \%$ & 1. $\mathrm{CF}$ & Gorton and Huang \\
\hline 10 & ManAG Markets for Toxic Assets & 2010 & $32 \%$ & $32 \%$ & $\begin{array}{l}\text { 1. } \mathrm{AP} \\
\text { 2. } \mathrm{EFG} \\
\text { 3. } \mathrm{ME}\end{array}$ & House and Masatlioglu \\
\hline 11 & $\begin{array}{l}\text { Dynamic Adverse Selection: A } \\
\text { Theory of Illiquidity, Fire Sales, and } \\
\text { Flight to Quality }\end{array}$ & 2012 & $32 \%$ & $38 \%$ & $\begin{array}{l}\text { 1. } \mathrm{AP} \\
\text { 2. } \mathrm{EFG}\end{array}$ & Guerrieri and Shimer \\
\hline 12 & Crisis Resolution and Bank Liquidity & 2009 & $32 \%$ & $32 \%$ & 1. $\mathrm{CF}$ & $\begin{array}{l}\text { Acharya, Shin, and } \\
\text { Yorulmazer }\end{array}$ \\
\hline 13 & On the Scholes Liquidation & 2009 & $32 \%$ & $32 \%$ & 1. AP & Brown, Carlin, and Lobo \\
\hline 14 & Liquidity and Risk Management & 2007 & $30 \%$ & $31 \%$ & 1. AP & Garlenanu and Pedersen \\
\hline 15 & $\begin{array}{l}\text { Market Liquidity, Asset Prices and } \\
\text { Welfare }\end{array}$ & 2008 & $29 \%$ & $29 \%$ & 1. AP & Huang and Wang \\
\hline 16 & $\begin{array}{l}\text { Banks' Advantage in Hedging } \\
\text { Liquidity Risk: Theory and Evidence } \\
\text { from the Commercial Paper Market }\end{array}$ & 2003 & $28 \%$ & $29 \%$ & 1. $\mathrm{CF}$ & Gatev and Strahan \\
\hline 17 & $\begin{array}{l}\text { Illiquid Assets and Optimal Portfolio } \\
\text { Choice }\end{array}$ & 2006 & $28 \%$ & $28 \%$ & 1. AP & Schwartz and Tebaldi \\
\hline 18 & $\begin{array}{l}\text { Liquidity Transformation in Asset } \\
\text { Management: Evidence from the } \\
\text { Cash Holdings of Mutual Funds }\end{array}$ & 2016 & $27 \%$ & $29 \%$ & $\begin{array}{l}\text { 1. } \mathrm{AP} \\
\text { 2. } \mathrm{CF}\end{array}$ & Chernenko and Sunderam \\
\hline
\end{tabular}




\begin{tabular}{|c|l|c|c|c|c|l|}
\hline 19 & $\begin{array}{l}\text { Amplification Mechanisms in } \\
\text { Liquidity Crises }\end{array}$ & 2009 & $26 \%$ & $52 \%$ & $\begin{array}{l}\text { 1. AP } \\
\text { 2. CF } \\
3 . \mathrm{ME}\end{array}$ & Krishnamurthy \\
\hline 20 & $\begin{array}{l}\text { Leverage and Asset Bubbles: } \\
\text { Averting Armageddon with Chapter } \\
11 ?\end{array}$ & 2010 & $26 \%$ & $40 \%$ & $3 . \mathrm{ME}$ & Miller and Stiglitz \\
\hline
\end{tabular}

\section{Top-20 WPs on the topic of 'Sovereign Debt'}

\begin{tabular}{|c|c|c|c|c|c|c|}
\hline & Title & Year & $\begin{array}{l}\% \text { of } \\
\text { topic }\end{array}$ & $\begin{array}{l}\% \text { of } \\
\text { crisis } \\
\text { topics }\end{array}$ & Programs & Authors \\
\hline 1 & $\begin{array}{l}\text { The Pitfalls of External Dependence: } \\
\text { Greece, } 1829-2015\end{array}$ & 2015 & $56 \%$ & $71 \%$ & $\begin{array}{l}\text { 1. IFM } \\
\text { 2. ME }\end{array}$ & Reinhart and Trebesch \\
\hline 2 & $\begin{array}{l}\text { Distributional Incentives in an } \\
\text { Equilibrium Model of Domestic } \\
\text { Sovereign Default }\end{array}$ & 2013 & $49 \%$ & $49 \%$ & $\begin{array}{l}\text { 1. IFM } \\
\text { 2. ME } \\
\text { 3. } \mathrm{PE}\end{array}$ & D'Erasmo and Mendoza \\
\hline 3 & $\begin{array}{l}\text { Sovereign Debt, Government } \\
\text { Myopia, and the Financial Sector }\end{array}$ & 2011 & $47 \%$ & $53 \%$ & $\begin{array}{l}\text { 1. IFM } \\
\text { 2. } \mathrm{ME} \\
\text { 3. EFG }\end{array}$ & Acharya and Rajan \\
\hline 4 & $\begin{array}{l}\text { A Theory of Debt Maturity: The } \\
\text { Long and Short of Debt Overhang }\end{array}$ & 2012 & $45 \%$ & $45 \%$ & 1. AP & Diamond and $\mathrm{He}$ \\
\hline 5 & $\begin{array}{l}\text { The Forgotten History of Domestic } \\
\text { Debt }\end{array}$ & 2008 & $43 \%$ & $43 \%$ & $\begin{array}{l}\text { 1. IFM } \\
\text { 2. PE }\end{array}$ & Reinhart and Rogoff \\
\hline 6 & Debt Intolerance & 2003 & $42 \%$ & $59 \%$ & 1. IFM & $\begin{array}{l}\text { Reinhart, Rogoff, and } \\
\text { Savastano }\end{array}$ \\
\hline 7 & $\begin{array}{l}\text { Self-Fulfilling Debt Crises: A } \\
\text { Quantitative Analysis }\end{array}$ & 2016 & $39 \%$ & $41 \%$ & $\begin{array}{l}\text { 1. IFM } \\
\text { 2. EFG }\end{array}$ & Bocola and Dovis \\
\hline 8 & $\begin{array}{l}\text { Optimal Domestic (and External) } \\
\text { Sovereign Default }\end{array}$ & 2016 & $39 \%$ & $39 \%$ & 1. IFM & D'Erasmo and Mendoza \\
\hline 9 & $\begin{array}{l}\text { Internal Debt Crises and Sovereign } \\
\text { Defaults }\end{array}$ & 2008 & $39 \%$ & $39 \%$ & $\begin{array}{l}\text { 1. IFM } \\
\text { 2. EFG }\end{array}$ & Arellano and Kocherlakota \\
\hline 10 & $\begin{array}{l}\text { Coordination and Crisis in Monetary } \\
\text { Unions }\end{array}$ & 2014 & $38 \%$ & $43 \%$ & $\begin{array}{l}\text { 1. IFM } \\
\text { 2. EFG } \\
\text { 3. } \mathrm{ME}\end{array}$ & $\begin{array}{l}\text { Aguiar, Amador, Farhi, and } \\
\text { Gopinath }\end{array}$ \\
\hline 11 & Tough Policies, Incredible Policies? & 2003 & $37 \%$ & $38 \%$ & 1. IFM & Velasco and Neut \\
\hline 12 & $\begin{array}{l}\text { Crisis and Commitment: Inflation } \\
\text { Credibility and the Vulnerability to } \\
\text { Sovereign Debt Crises }\end{array}$ & 2013 & $37 \%$ & $49 \%$ & $\begin{array}{l}\text { 1. IFM } \\
\text { 2. } \mathrm{EFG} \\
\text { 3. } \mathrm{ME}\end{array}$ & $\begin{array}{l}\text { Aguiar, Amador, Farhi, and } \\
\text { Gopinath }\end{array}$ \\
\hline 13 & A Brazilian Debt-Crisis Model & 2002 & $36 \%$ & $36 \%$ & 1. IFM & Razin and Sadka \\
\hline 14 & $\begin{array}{l}\text { The Long and the Short of It: } \\
\text { Sovereign Debt Crises and Debt } \\
\text { Maturity }\end{array}$ & 2014 & $36 \%$ & $42 \%$ & $\begin{array}{l}\text { 1. IFM } \\
\text { 2. EFG }\end{array}$ & Fernández and Martin \\
\hline 15 & A Brazilian Debt-Crisis & 2002 & $36 \%$ & $43 \%$ & 1. IFM & Razin and Sadka \\
\hline 16 & $\begin{array}{l}\text { Sovereign Debt Markets in Turbulent } \\
\text { Times: Creditor Discrimination and } \\
\text { Crowding-Out Effects }\end{array}$ & 2013 & $36 \%$ & $51 \%$ & 1. EFG & $\begin{array}{l}\text { Broner, Erce, Martin, and } \\
\text { Ventura }\end{array}$ \\
\hline
\end{tabular}




\begin{tabular}{|c|l|c|c|c|c|l|}
\hline 17 & Monetary Policy and Debt Fragility & 2014 & $35 \%$ & $35 \%$ & 1 . EFG & Cooper and Camous \\
\hline 18 & Slow Moving Debt Crises & 2013 & $34 \%$ & $35 \%$ & $\begin{array}{l}\text { 1. IFM } \\
\text { 2. EFG } \\
\text { 3. ME }\end{array}$ & Lorenzoni and Werning \\
\hline 19 & $\begin{array}{l}\text { The U.S. Debt Restructuring of 1933: } \\
\text { Consequences and Lessons }\end{array}$ & 2015 & $32 \%$ & $32 \%$ & $\begin{array}{l}\text { 2. IFM } \\
\text { 3. DAE }\end{array}$ & $\begin{array}{l}\text { Edwards, Longstaff, and } \\
\text { Marin }\end{array}$ \\
\hline 20 & $\begin{array}{l}\text { The Stock of External Sovereign } \\
\text { Debt: Can We Take the Data At 'Face } \\
\text { Value'? }\end{array}$ & 2011 & $32 \%$ & $32 \%$ & Dias, Richmond, and Wright \\
\hline
\end{tabular}

7. Top-20 WPs on the topic of 'Emerging Markets'

\begin{tabular}{|c|c|c|c|c|c|c|}
\hline & Title & Year & $\begin{array}{l}\% \text { of } \\
\text { topic }\end{array}$ & $\begin{array}{l}\% \text { of } \\
\text { crisis } \\
\text { topics }\end{array}$ & Programs & Authors \\
\hline 1 & $\begin{array}{l}\text { Keeping Capital Flowing: The Role } \\
\text { of the IMF }\end{array}$ & 2004 & $34 \%$ & $34 \%$ & 1. IFM & Bordo, Mody, and Oomes \\
\hline 2 & Local Currency Bond Markets & 2006 & $30 \%$ & $34 \%$ & 1. IFM & Burger and Warnock \\
\hline 3 & $\begin{array}{l}\text { Terms of Trade Shocks and Fiscal } \\
\text { Cycles }\end{array}$ & 2010 & $29 \%$ & $29 \%$ & 1. IFM & Kaminsky \\
\hline 4 & $\begin{array}{l}\text { Can Inflation Targeting Work in } \\
\text { Emerging Market Countries? }\end{array}$ & 2004 & $29 \%$ & $32 \%$ & $\begin{array}{l}\text { 1. IFM } \\
\text { 2. ME } \\
\text { 3. } \mathrm{EFG}\end{array}$ & Mishkin \\
\hline 5 & $\begin{array}{l}\text { Explaining Foreign Holdings of } \\
\text { Asia's Debt Securities: The Feldstein- } \\
\text { Horioka Paradox Revisited }\end{array}$ & 2015 & $26 \%$ & $32 \%$ & $\begin{array}{l}\text { 1. IFM } \\
\text { 2. DEV } \\
\text { 3. EFG }\end{array}$ & $\begin{array}{l}\text { Horioka, Terada- Hagiwara, } \\
\text { and Nomoto }\end{array}$ \\
\hline 6 & $\begin{array}{l}\text { Currency Mismatches, Debt } \\
\text { Intolerance and Original Sin: Why } \\
\text { They Are Not the Same and Why it } \\
\text { Matters }\end{array}$ & 2003 & $26 \%$ & $43 \%$ & 1. IFM & $\begin{array}{l}\text { Eichngreen, Hausmann, and } \\
\text { Panizza }\end{array}$ \\
\hline 7 & $\begin{array}{l}\text { Exchange Rate Regimes and Capital } \\
\text { Mobility: How Much of the Swoboda } \\
\text { Thesis Survives? }\end{array}$ & 2008 & $26 \%$ & $26 \%$ & 1. IFM & Eichngreen \\
\hline 8 & $\begin{array}{l}\text { The International Monetary Fund: Its } \\
\text { Present Role in Historical Perspective }\end{array}$ & 2000 & $26 \%$ & $26 \%$ & $\begin{array}{l}\text { 1. IFM } \\
\text { 2. DAE }\end{array}$ & Bordo and James \\
\hline 9 & $\begin{array}{l}\text { How Reliable are De Facto Exchange } \\
\text { Rate Regime Classifications? }\end{array}$ & 2011 & $24 \%$ & $32 \%$ & 1. IFM & Eichngreen and Razo-Garcia \\
\hline 10 & $\begin{array}{l}\text { Exchange Rate Regime Durability } \\
\text { and Performance in Developing } \\
\text { Countries Versus Advanced } \\
\text { Economies }\end{array}$ & 2004 & $23 \%$ & $24 \%$ & $\begin{array}{l}\text { 1. IFM } \\
\text { 2. EFG } \\
\text { 3. } \mathrm{ME}\end{array}$ & Husain, Mody, and Rgoff \\
\hline 11 & $\begin{array}{l}\text { When did the dollar overtake sterling } \\
\text { as the leading international currency? } \\
\text { Evidence from the bond markets }\end{array}$ & 2012 & $23 \%$ & $27 \%$ & $\begin{array}{l}\text { 1. IFM } \\
\text { 2. DAE }\end{array}$ & Chitu, Eichngreen, and Mehl \\
\hline 12 & $\begin{array}{l}\text { Exchange Rate Regime Choice in } \\
\text { Historical Perspective }\end{array}$ & 2003 & $22 \%$ & $22 \%$ & $\begin{array}{l}\text { 1. IFM } \\
\text { 2. DAE }\end{array}$ & Bordo \\
\hline 13 & $\begin{array}{l}\text { Transmission of the U.S. Subprime } \\
\text { Crisis to Emerging Markets: }\end{array}$ & 2009 & $22 \%$ & $68 \%$ & 1. IFM & Dooley and Hutchison \\
\hline
\end{tabular}




\begin{tabular}{|c|c|c|c|c|c|c|}
\hline & $\begin{array}{l}\text { Evidence on the Decoupling- } \\
\text { Recoupling Hypothesis }\end{array}$ & & & & & \\
\hline 14 & $\begin{array}{l}\text { Country Spreads and Emerging } \\
\text { Countries: Who Drives Whom? }\end{array}$ & 2003 & $22 \%$ & $22 \%$ & $\begin{array}{l}\text { 1. IFM } \\
\text { 2. EFG }\end{array}$ & Uribe and Yue \\
\hline 15 & $\begin{array}{l}\text { Are Hard Pegs Ever Credible in } \\
\text { Emerging Markets? Evidence from } \\
\text { the Classical Gold Standard }\end{array}$ & 2009 & $21 \%$ & $21 \%$ & $\begin{array}{l}\text { 1. IFM } \\
\text { 2. DAE }\end{array}$ & Mitchener and Weidenmier \\
\hline 16 & $\begin{array}{l}\text { Inflation Targeting in Emerging } \\
\text { Market Economies }\end{array}$ & 2003 & $21 \%$ & $21 \%$ & $\begin{array}{l}\text { 1. IFM } \\
\text { 2. EFG } \\
\text { 3. } \mathrm{ME}\end{array}$ & Fraga, Goldfajn, and Minella \\
\hline 17 & Okun's Law: Fit at Fifty? & 2013 & $21 \%$ & $29 \%$ & $\begin{array}{l}\text { 1. EFG } \\
\text { 3. ME }\end{array}$ & Ball, Leigh, and Loungani \\
\hline 18 & $\begin{array}{l}\text { Inflation Targeting in Emerging } \\
\text { Market Countries }\end{array}$ & 2000 & $21 \%$ & $21 \%$ & $\begin{array}{l}\text { 1. IFM } \\
\text { 2. EFG } \\
\text { 3. } \mathrm{ME}\end{array}$ & Mishkin \\
\hline 19 & $\begin{array}{l}\text { The Mirage of Exchange Rate } \\
\text { Regimes for Emerging Market } \\
\text { Countries }\end{array}$ & 2003 & $21 \%$ & $21 \%$ & $\begin{array}{l}\text { 1. IFM } \\
\text { 2. ME }\end{array}$ & Calvo and Mishkin \\
\hline 20 & $\begin{array}{l}\text { Learning From the Doers: } \\
\text { Developing Country Lessons for } \\
\text { Advanced Economy Growth }\end{array}$ & 2005 & $20 \%$ & $20 \%$ & $\begin{array}{l}\text { 1. IFM } \\
\text { 2. EFG }\end{array}$ & Chary and Henry \\
\hline
\end{tabular}

8. Top-20 WPs on the topic of 'Repo and Securitization'

\begin{tabular}{|c|c|c|c|c|c|c|}
\hline & Title & Year & $\begin{array}{l}\text { \% of } \\
\text { topic }\end{array}$ & $\begin{array}{l}\% \text { of } \\
\text { crisis } \\
\text { topics }\end{array}$ & Programs & Authors \\
\hline 1 & The Alchemy of CDO Credit Ratings & 2009 & $57 \%$ & $57 \%$ & 1. $\mathrm{CF}$ & Benmelech and Dlugosz \\
\hline 2 & $\begin{array}{l}\text { Did Securitization Affect the Cost of } \\
\text { Corporate Debt? }\end{array}$ & 2011 & $55 \%$ & $55 \%$ & 1. $\mathrm{CF}$ & Nadauld and Weisbach \\
\hline 3 & $\begin{array}{l}\text { Securitization without Adverse } \\
\text { Selection: The Case of CLOs }\end{array}$ & 2011 & $54 \%$ & $54 \%$ & 1. $\mathrm{CF}$ & $\begin{array}{l}\text { Benmelech, Dlugosz, and } \\
\text { Ivashina }\end{array}$ \\
\hline 4 & Sizing Up Repo & 2012 & $48 \%$ & $53 \%$ & $\begin{array}{l}\text { 1. } \mathrm{AP} \\
\text { 2. ME } \\
\text { 3. } \mathrm{CF}\end{array}$ & $\begin{array}{l}\text { Krishnamurthy, Nagel, and } \\
\text { Orlov }\end{array}$ \\
\hline 5 & $\begin{array}{l}\text { Securitized Banking and the Run on } \\
\text { Repo }\end{array}$ & 2009 & $46 \%$ & $49 \%$ & $\begin{array}{l}\text { 1. } \mathrm{AP} \\
\text { 2. } \mathrm{ME} \\
\text { 3. } \mathrm{CF} \\
\text { 4. } \mathrm{EFG}\end{array}$ & Gorton and Metrick \\
\hline 6 & $\begin{array}{l}\text { Unintended Consequences of LOLR } \\
\text { Facilities: The Case of Illiquid } \\
\text { Leverage }\end{array}$ & 2013 & $44 \%$ & $59 \%$ & $\begin{array}{l}\text { 1. } \mathrm{AP} \\
\text { 2. } \mathrm{ME} \\
\text { 3. } \mathrm{CF}\end{array}$ & Acharya and Tuckman \\
\hline 7 & The Credit Rating Crisis & 2009 & $43 \%$ & $43 \%$ & $\begin{array}{l}\text { 1. } \mathrm{AP} \\
\text { 2. } \mathrm{ME} \\
\text { 3. } \mathrm{CF} \\
\text { 4. } \mathrm{LE}\end{array}$ & Benmelech and Dlugosz \\
\hline 8 & $\begin{array}{l}\text { Balance Sheet Adjustments in the } \\
2008 \text { Crisis }\end{array}$ & 2010 & $42 \%$ & $60 \%$ & $\begin{array}{l}\text { 1. } \mathrm{AP} \\
\text { 2. } \mathrm{ME}\end{array}$ & $\begin{array}{l}\text { He, Khang, and } \\
\text { Krishnamurthy }\end{array}$ \\
\hline
\end{tabular}




\begin{tabular}{|c|c|c|c|c|c|c|}
\hline & & & & & 3. $\mathrm{CF}$ & \\
\hline 9 & Tri-Party Repo Pricing & 2015 & $40 \%$ & $40 \%$ & 1. AP & $\mathrm{Hu}, \mathrm{Pan}$, and Wang \\
\hline 10 & $\begin{array}{l}\text { The Rise and Fall of Demand for } \\
\text { Securitizations }\end{array}$ & 2014 & $39 \%$ & $56 \%$ & $\begin{array}{l}\text { 1. } \mathrm{AP} \\
\text { 2. } \mathrm{CF}\end{array}$ & $\begin{array}{l}\text { Chernenko, Hanson, and } \\
\text { Sunderam }\end{array}$ \\
\hline 11 & Securitization without risk transfer & 2010 & $38 \%$ & $44 \%$ & $\begin{array}{l}\text { 1. } \mathrm{AP} \\
\text { 2. } \mathrm{CF}\end{array}$ & $\begin{array}{l}\text { Acharya, Schnabel, and } \\
\text { Suarez }\end{array}$ \\
\hline 12 & $\begin{array}{l}\text { CMBS Subordination, Ratings } \\
\text { Inflation, and the Crisis of 2007-2009 }\end{array}$ & 2010 & $36 \%$ & $36 \%$ & 1. AP & Stanton and Wallace \\
\hline 13 & The Credit Ratings Game & 2009 & $35 \%$ & $35 \%$ & $\begin{array}{l}\text { 1. IO } \\
\text { 2. } \mathrm{CF}\end{array}$ & Bolton, Freixas, and Shapiro \\
\hline 14 & $\begin{array}{l}\text { Why Did U.S. Banks Invest in } \\
\text { Highly-Rated Securitization } \\
\text { Tranches? }\end{array}$ & 2011 & $35 \%$ & $35 \%$ & 1. $\mathrm{CF}$ & Erel, Nadauld, and Stulz \\
\hline 15 & $\begin{array}{l}\text { Adverse Selection, Reputation and } \\
\text { Sudden Collapses in Secondary Loan } \\
\text { Markets }\end{array}$ & 2010 & $33 \%$ & $33 \%$ & $\begin{array}{l}\text { 1. } \mathrm{CF} \\
\text { 2. } \mathrm{EFG}\end{array}$ & $\begin{array}{l}\text { Chari, Shourideh, and Zetlin- } \\
\text { Jones }\end{array}$ \\
\hline 16 & $\begin{array}{l}\text { An Empirical Analysis of the Fed's } \\
\text { Term Auction Facility }\end{array}$ & 2012 & $32 \%$ & $32 \%$ & $\begin{array}{l}\text { 1. } \mathrm{CF} \\
\text { 2. EFG } \\
\text { 3. AP }\end{array}$ & Benmelech \\
\hline 17 & Who Ran on Repo? & 2012 & $31 \%$ & $31 \%$ & $\begin{array}{l}\text { 1. } \mathrm{AP} \\
\text { 2. } \mathrm{ME} \\
\text { 3. } \mathrm{CF}\end{array}$ & Gorton and Metrick \\
\hline 18 & Fighting Crises & 2016 & $31 \%$ & $31 \%$ & $\begin{array}{l}\text { 1. } \mathrm{AP} \\
\text { 2. } \mathrm{ME} \\
\text { 3. } \mathrm{EFG}\end{array}$ & Gorton and Ordonez \\
\hline 19 & $\begin{array}{l}\text { Asset Quality Misrepresentation by } \\
\text { Financial Intermediaries: Evidence } \\
\text { from RMBS Market }\end{array}$ & 2005 & $30 \%$ & $31 \%$ & $\begin{array}{l}\text { 1. } \mathrm{AP} \\
\text { 2. } \mathrm{CF} \\
\text { 3. } \mathrm{LE}\end{array}$ & Piskorski, Seru, and Witikin \\
\hline 20 & Securitization & 2012 & $29 \%$ & $40 \%$ & $\begin{array}{l}\text { 1. } \mathrm{AP} \\
\text { 2. } \mathrm{ME} \\
\text { 3. } \mathrm{CF} \\
\text { 4. } \mathrm{EFG}\end{array}$ & Gorton and Metrick \\
\hline
\end{tabular}

\section{Top-20 WPs on the topic of 'Great Recession'}

\begin{tabular}{|c|l|c|c|c|c|l|}
\hline \multicolumn{1}{|c|}{ Title } & Year & $\begin{array}{c}\text { \% of } \\
\text { topic }\end{array}$ & $\begin{array}{c}\text { \% of } \\
\text { crisis } \\
\text { topics }\end{array}$ & Programs & Authors \\
\hline 1 & $\begin{array}{l}\text { Deep Recessions, Fast Recoveries, } \\
\text { and Financial Crises: Evidence from } \\
\text { the American Record }\end{array}$ & 2012 & $53 \%$ & $62 \%$ & $\begin{array}{l}\text { 1. ME } \\
2 . \text { DAE }\end{array}$ & Bordo and Haubrich \\
\hline 2 & $\begin{array}{l}\text { Reallocation in the Great Recession: } \\
\text { Cleansing or Not? }\end{array}$ & 2014 & $40 \%$ & $40 \%$ & $\begin{array}{l}\text { 1. IS } \\
\text { 2. PR } \\
\text { 3. EFG }\end{array}$ & Foster, Grim, and Haltiwanger \\
\hline 3 & $\begin{array}{l}\text { The Trend is the Cycle: Job } \\
\text { Polarization and Jobless Recoveries }\end{array}$ & 2012 & $38 \%$ & $38 \%$ & $\begin{array}{l}\text { 1. IS } \\
\text { 2. EFG }\end{array}$ & Jaimovich and Siu \\
\hline 4 & $\begin{array}{l}\text { Forecasting the Recovery from the } \\
\text { Great Recession: Is This Time } \\
\text { Different? }\end{array}$ & 2013 & $37 \%$ & $39 \%$ & $\begin{array}{l}\text { 1. EFG } \\
\text { 2. ME }\end{array}$ & Dominguez and Shapiro \\
\hline
\end{tabular}




\begin{tabular}{|c|c|c|c|c|c|c|}
\hline 5 & $\begin{array}{l}\text { The Great Recession in the Shadow } \\
\text { of the Great Depression: A Review } \\
\text { Essay on Hall of Mirrors }\end{array}$ & 2016 & $37 \%$ & $37 \%$ & $\begin{array}{l}\text { 1. } \mathrm{EFG} \\
\text { 2. } \mathrm{ME}\end{array}$ & Ohanian \\
\hline 6 & $\begin{array}{l}\text { Slow Recoveries: A Structural } \\
\text { Interpretation }\end{array}$ & 2012 & $37 \%$ & $37 \%$ & 1. IFM & Gali, Smets, and Wouters \\
\hline 7 & $\begin{array}{l}\text { Lifecycle Effects of a Recession on } \\
\text { Health Behaviors: Boom, Bust, and } \\
\text { Recovery in Iceland }\end{array}$ & 2015 & $35 \%$ & $40 \%$ & $\begin{array}{l}\text { 1. } \mathrm{HC} \\
\text { 2. } \mathrm{HE}\end{array}$ & $\begin{array}{l}\text { Ásgeirsdóttir, Corman, and } \\
\text { Reichman }\end{array}$ \\
\hline 8 & International Recessions & 2011 & $35 \%$ & $48 \%$ & $\begin{array}{l}\text { 1. IFM } \\
\text { 2. EFG }\end{array}$ & Perri and Quaderini \\
\hline 9 & $\begin{array}{l}\text { Anticipating the Great Depression? } \\
\text { Gustav Cassel's Analysis of the } \\
\text { Interwar Gold Standard }\end{array}$ & 2011 & $34 \%$ & $34 \%$ & $\begin{array}{l}\text { 1. IFM } \\
\text { 2. ME } \\
\text { 3. DAE }\end{array}$ & Irwin \\
\hline 10 & $\begin{array}{l}\text { How Could Everyone Have Been So } \\
\text { Wrong? Forecasting the Great } \\
\text { Depression with the Railroads }\end{array}$ & 2002 & $32 \%$ & $32 \%$ & 1. DAE & $\begin{array}{l}\text { Landon-Lane, White, and } \\
\text { Klug }\end{array}$ \\
\hline 11 & $\begin{array}{l}\text { The Great Recession, Decline and } \\
\text { Rebound in Household Wealth for } \\
\text { the Near Retirement Population }\end{array}$ & 2014 & $32 \%$ & $32 \%$ & $\begin{array}{l}\text { 1. AG } \\
\text { 2. IS } \\
\text { 3. PE }\end{array}$ & $\begin{array}{l}\text { Gustman, Stienmeier, and } \\
\text { Tabatabai }\end{array}$ \\
\hline 12 & $\begin{array}{l}\text { Stock-Market Crashes and } \\
\text { Depressions }\end{array}$ & 2009 & $32 \%$ & $33 \%$ & $\begin{array}{l}\text { 1. AP } \\
\text { 2. IFM } \\
\text { 3. EFG }\end{array}$ & Barro and Ursúa \\
\hline 13 & $\begin{array}{l}\text { The Great Depression and the Great } \\
\text { Recession: A View from Financial } \\
\text { Markets }\end{array}$ & 2015 & $31 \%$ & $31 \%$ & $\begin{array}{l}\text { 1. } \mathrm{EFG} \\
\text { 2. ME } \\
\text { 3. AP }\end{array}$ & Bianchi \\
\hline 14 & $\begin{array}{l}\text { Endogenous Technology Adoption } \\
\text { and R\&D as Sources of Business } \\
\text { Cycle Persistence }\end{array}$ & 2016 & $31 \%$ & $31 \%$ & $\begin{array}{l}\text { 1. IFM } \\
\text { 2. ME } \\
\text { 3. DAE } \\
\text { 4. AP } \\
\text { 5. PR } \\
\end{array}$ & $\begin{array}{l}\text { Anzoategui, Comin, } \\
\text { Gertler, and Martinez }\end{array}$ \\
\hline 15 & $\begin{array}{l}\text { Failing the Test? The Flexible U.S. } \\
\text { Job Market in the Great Recession }\end{array}$ & 2013 & $30 \%$ & $30 \%$ & 1. IS & Freeman \\
\hline 16 & $\begin{array}{l}\text { Reconciling Hayek's and Keynes } \\
\text { Views of Recessions }\end{array}$ & 2014 & $29 \%$ & $29 \%$ & 1. EFG & Beaudry, Galizia, and Portier \\
\hline 17 & $\begin{array}{l}\text { Disentangling the Channels of the } \\
\text { 2007-2009 Recession }\end{array}$ & 2012 & $29 \%$ & $29 \%$ & $\begin{array}{l}\text { 1. } \mathrm{ME} \\
\text { 2. } \mathrm{EFG}\end{array}$ & Stock and Watson \\
\hline 18 & $\begin{array}{l}\text { Sovereigns versus Banks: Credit, } \\
\text { Crises, and Consequences }\end{array}$ & 2013 & $29 \%$ & $54 \%$ & $\begin{array}{l}\text { 1. DAE } \\
\text { 2. IFM } \\
\text { 3. ME }\end{array}$ & Jordà, Schularic,k and Taylor \\
\hline 19 & A Model of Secular Stagnation & 2014 & $29 \%$ & $29 \%$ & 1. $\mathrm{ME}$ & $\begin{array}{l}\text { Eggertsson, Mehrotra, } \\
\text { and Robbins }\end{array}$ \\
\hline 20 & $\begin{array}{l}\text { Quantifying the Lasting Harm to the } \\
\text { U.S. Economy from the Financial } \\
\text { Crisis }\end{array}$ & 2014 & $28 \%$ & $29 \%$ & 1. EFG & Hall \\
\hline
\end{tabular}

